Portland State University

PDXScholar

1987

\title{
The Impact of Physical Environment on the Social Climate of Two Jails
}

James G. Houston

Portland State University

Follow this and additional works at: https://pdxscholar.library.pdx.edu/open_access_etds Let us know how access to this document benefits you.

\section{Recommended Citation}

Houston, James G., "The Impact of Physical Environment on the Social Climate of Two Jails" (1987). Dissertations and Theses. Paper 1139.

https://doi.org/10.15760/etd.1138

This Dissertation is brought to you for free and open access. It has been accepted for inclusion in Dissertations and Theses by an authorized administrator of PDXScholar. Please contact us if we can make this document more accessible: pdxscholar@pdx.edu. 
THE IMPACT OF PHYSICAL ENVIRONMENT

ON THE SOCIAL CLIMATE OF TWO JAILS

by

JAMES G. HOUSTON

A dissertation submitted in partial fulfillment of the requirements for the degree of

Doctor of Philosophy

in

Urban Studies

Portland State University

Cd 987 
TO THE OFFICE OF GRADUATE STUDIES AND RESEARCH:

The members of the Committee approve the dissertation of James G. Houston presented November 18, 1987.
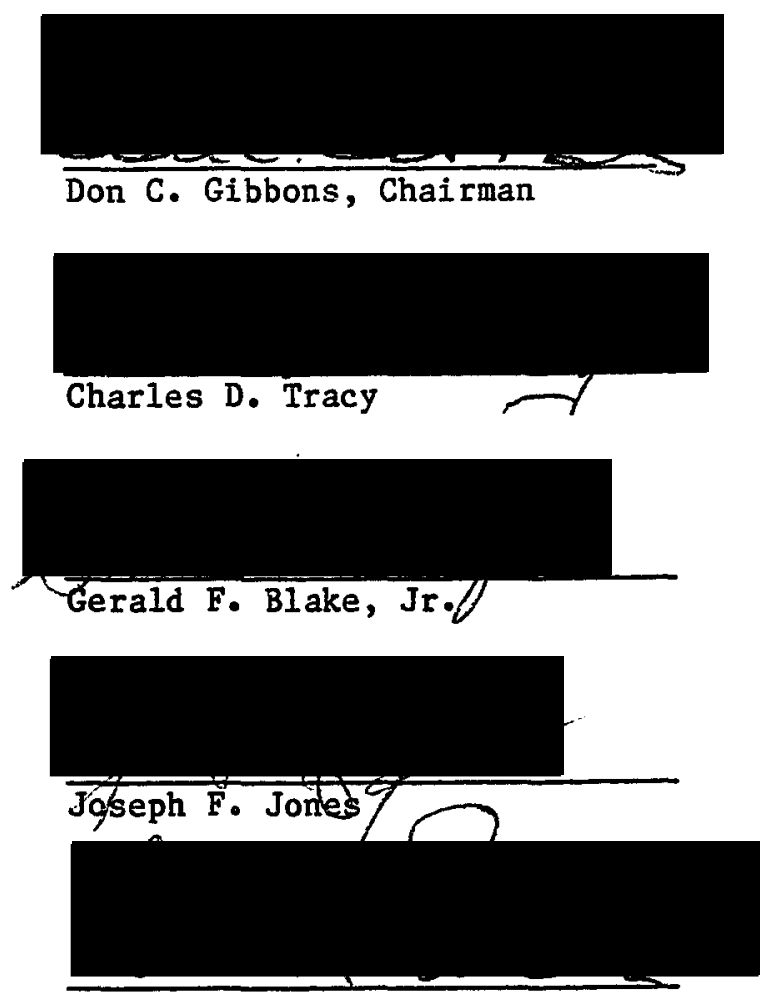

Arthur C. Emlen

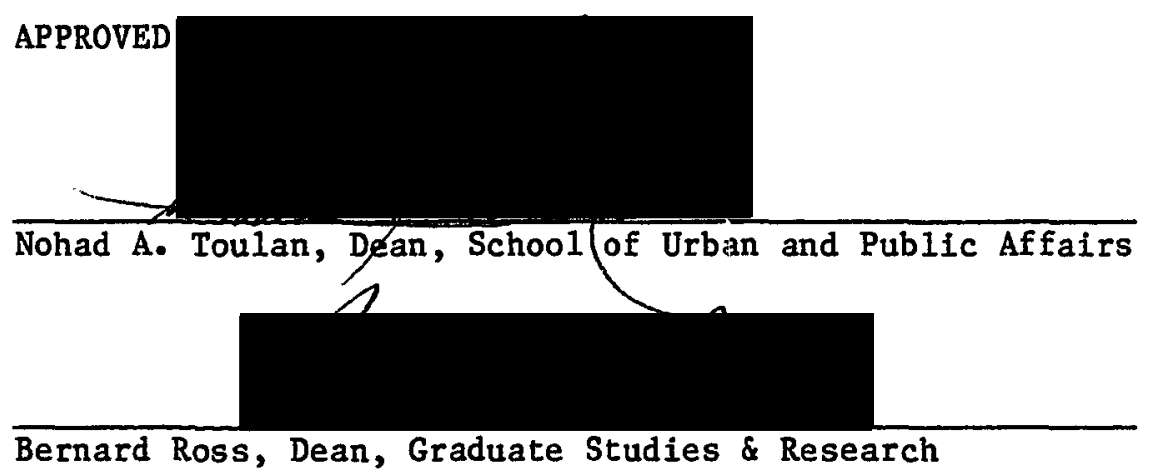


AN ABSTRACT OF THE DISSERTATION OF James G. Houston for the Doctor of

Philosophy in Urban Studỉes presented November 18, 1987.

Title: The Impact of Physical Environment on the Social Climate of Two Jails.

APPROVED BY MEMBERS OF THE DISSERTATION COMMTTTEE:
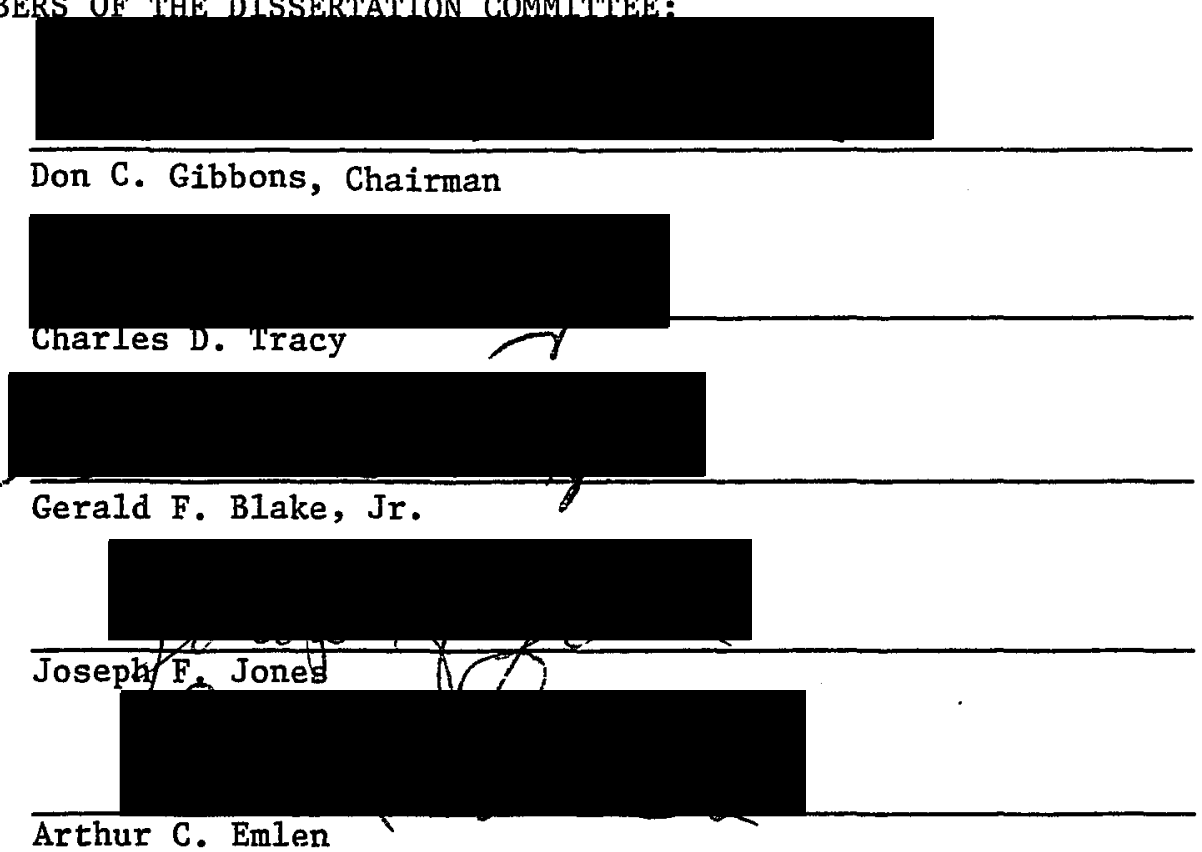

There has been a strong movement across the United States in recent years to replace outdated and inadequate jails. According to the National Sheriff's Association, about one quarter of the 3,493 jails in the United States are 50 or more years old and many others are badly in need of repair or replacement. Accordingly, the anticipated need in jail construction has given birth to a new area of expertice among architects and contractors jail design and construction.

While design and construction philosophy and techniques have improved, little is known of the effects of physical environment on the social climate of a jail. This question is part of a larger one, namely, does physical environment affect behavior generally? The question of what kind of physical 
environment alterations affect the social climate of a jail has broad implications with regard to design and construction of these and other secure facilities. If the answer to the question an be determined, it may be possible to improve service delivery in local jails, increase staff satisEaction with the work environment in them, and improve mental and emotional health of jail staff and inmates; all of which can be translated into savings to the taxpayer.

In this study of three local jails the Correctional Institution Environment Scale (CIES) was administered to volunteer inmates and staff at an old outdated jail soon to be replaced and to two control jails that were comparable in size, age, and population makeup. One year later after the old jail had been vacated in favor of a new, ultra-modern high rise jail, the CIES was again administered to the inmates and staff at the new facility and the two control institutions.

Subscale means on the CIES for all groups were obtained, enabling the researcher to compare groups within the jails and to compare the jails with each other. The second step in examining the data was to perform an analysis of covariance, controlling for age, sex, status, $\mathrm{T}_{1}$ (length of time, served or worked, in jail this time), and $\mathrm{T}_{2}$ (how long have you served or worked in jails or prisions in your life?).

The results were inconclusive and cell means indicated that the new high rise jail was not perceived by inmates and staff as having a particularly favorable social climate. Nonsignificant $F$ ratios were obtained for the subscales of Involvement (.209), Expression (.987), Autonomy (.274), and Practical Orientation (.132). Significant $\mathrm{F}$ ratios were obtained for Support $(.004)$, Order and Organization (.001), Clarity (.001), and Staff Control $(.001)$. 
More generally, it was concluded that alterations in physical environment had no overall impact on the perceptions of staff and inmates of social climate in the jails studied; the existence of thorough and well written policies and procedures did affect staff and inmate perceptions of how well a jail is managed.

The research suggests that if a community is faced with the need to replace or renovate an old outdated jail, there may be an alternative to expensive construction programs. That is, rehabilitation of the existing jail, coupled with thorough and well written policies and procedures may be as effective as expensive new construction. 


\section{ACKNOWLEDGEMENTS}

The completion of this dissertation culminates a four year effort during which many individuals provided assistance, cooperation, and support. I wish to express my appreciation to $\mathrm{Dr}$. Don C. Gibbons, my advisor and dissertation director, for his consistent and straightforward guidance at every step of the process. I am also grateful to my other committee members. Dr. Charles D. Tracy, Dr. Gerald F. Blake, Jr., Dr. Joseph F. Jones, and Dr. Arthur C. Emlen devoted much time and their input should not be overlooked. A special "thank you" goes to Dr. William Rabiega and Mr. Edward Shaffer both of whom made themselves available for consultation.

I am deeply indebted to Multnomah County Sheriff Fred B. Pearce, without whose cooperation and support this study would not have been possible. In addition, I would like to thank Sheriff Roger McDermott of Sonoma County, California and Sheriff N. D. (Pete) Haywood of Salt Lake County, Utah for allowing me to go into their jails and administer the questionnaires. An expression of gratitude is also extended to the correctional officers and inmates who participated in the study.

Two people provided invaluable technical assistance in the preparation of this disseztation. A very special thanks goes to Mrs. Sue Dayhuff for her tireless efforts in typing numerous drafts and assembling the final copy of the document. Gratitude is extended to Mrs. Carol Walker for her assistance in statistical analysis and to Mr. Doug Smith 
for allowing me to use the computer facilities of Indiana State University.

The completion of requirements leading to a Ph.D. in Urban Studies would not have been possible without the support and encouragement of my family. I am especially grateful to my children, Melinda, Andrew, and Meredith for their patience on those many occasions when I was at the library or computer lab instead of home. Finally, I offer my greatest appreciation to my wife Peggy who provided the emotional support, understanding, and inspiration I needed to achieve the goal of Ph.D. 
TABLE OF CONTENTS

PAGE

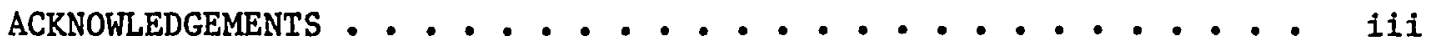

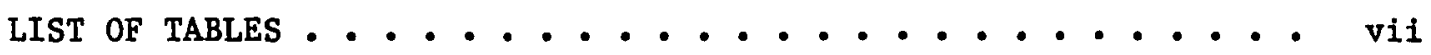

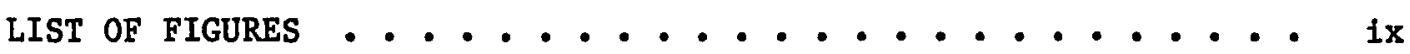

CHAPTER

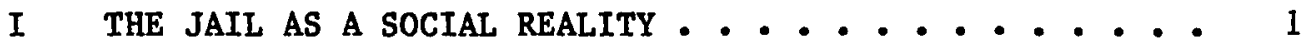

Introduction . . . . . . . . . . . . . . . 1

Organization of the Study ............... 2

The Development of the Jail . = . . . . . . - 4

Social Organization of the Prison and Jail. . . . . 8

One View of Jails . . . . . . . . . . . 12

Summary . . . . . . . . . . . . . . . 16

II JAILS, ARCHITECTURE, AND SOCIAL CLIMATE 20

Introduction. . . . . . . . . . . . . 20

Environmental Influence on Behavior . . . . . . . 20

Individual Responses. - . . . . . . . . . 22

Organizational climate. . . . . . . . . . . 24

Organizational Climate in Correctional Institutions . 27

Jails and Social Climate. . . . . . . . . 31

Importance of the study . . . . . . . . . . 33

Summary . . . . . . . . . . . . . . . 34 
CHAPTER

III A HISTORICAL AND DESCRIPTIVE OVERVIEW OF THE MULTNOMAH COUNTY JAIL SYSTEM AND THE NEW MULTNOMAH COUNTY DETENTION CENTER . . . . . . . . . . . 38

System Overview . . . . . . . . . . 38

Rocky Butte Jail. . . . . . . . . 42

Multnomah County Detention Center ....... 51

Functional Unit Management. . . . . . . 59

IV THE RESEARCH PROBLEM ............ 63

Statistical Analysis. .......... 73

$\checkmark \quad$ DATA ANALYSIS AND FINDINGS . . . . . . . . . 82

Jail Staff. . . . . . . . . . 83

Ja11 Inmates. . . . . . . . . . 85

CIES Results................ 88

Statistical Analysis. ........... 101

Analysis of Disciplinary Reports. . . . . . 137

Discussion. . . . . . . . . . 140

VI SUMMARY, IMPLICATIONS AND RECOMMENDATIONS. . . . • 153

Summary . . . . . . . . . . . 157

Implications and Recommendations. . . . . . 157

LITERATURE CITED. . . . . . . . . . . . . 165

APPENDIX. . . . . . . . . . . . . . . . . 172 
LIST OF TABLES

TABLE

PAGE

I Ancova - Involvement . . . . . . . . . 77

II Study Sample . . . . . . . . . . 79

III RBJ/MCDC Inmate Age Distribution .......... 86

IV SCJ Inmate Age Distribution ............ 86

V SLC Inmate Age Distribution. . . . . . . . 87

VI CIES Scores for All Jails (Male) . . . . . . . 89

VII CIES Scores for All Jalls (Female).......... 90

VIII ANCOVA - Involvement ............ 112

IX ANCOVA - Support ................ 113

X ANCOVA - Expressiveness. . . . . . . . . 114

XI ANCOVA - Autonomy. ............ 115

XII ANCOVA - Practical Orientation .......... 116

XIII ANCOVA - Personal Problem Orientation. . . . . . 117

XIV ANCOVA - Order and Organization. ......... 118

XV ANCOVA - Clarity ............... 119

XVI ANCOVA - staff Control ............ 121

XVII Involvement - Age Mean Scores After ANCOVA for Staff and Inmates ............. . . 124

XVIII Support - Age Mean Scores After ANCOVA for Staff and Inmates . . . . . . . . . . 125

XIX Expressiveness - Age Mean Scores After ANCOVA for Staff

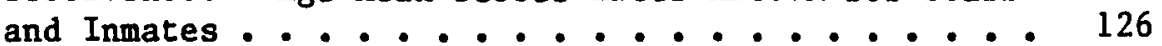


viil

XX Autonomy - Age Mean Scores After ANCOVA for Staff and Inmates ............. . 127

XXI Practical Orientation - Age Mean Scores After ANCOVA for Staff and Inmates .......... 128

XXII Personal Problem Orientation - Age Mean Scores After ANCOVA for Staff and Inmates. . . . . . . 129

XXIII Order and Organization - Age Mean Scores After ANCOVA for Staff and Inmates .......... 130

XXIV Clarity - Age Mean Scores After ANCOVA for Staff and Inmates ............. 131

XXV Staff Control - Age Mean Scores After ANCOVA for Staff and Inmates .............. 132

XXVI Relationship Dimension (Status by Year). . . . . 133

XXVII Program Dimension (Status by Year) . . . . . 134

XXVIII System Maintenance Dimension (Status by Year). . . . 135 
LIST OF FIGURES

FIGURE

PAGE

1. General Layout - RBJ. ..............

2. A \& B Tanks ................ . . 45

3. C Tank. ..................... 46

4. D and G Tanks ................ 47

5. E and F Tanks ............... 48

6. R Tank and Isolation Unit ............. 49

7. Vertical Plan - MCDC. ........... 54

8. Intake/Booking. . . . . . . . . . . 56

9. General Housing - Floors 5-9........... 58

10. Analysis of Covariance Staff and Inmates -

Involvement. ................ 78

11. Social C1imate Scale Profile - RBJ/MCDC

Male Inmate and Staff.......... 95

12. Social C1imate Scale Profile - RBJ/MCDC

Female Inmate and Staff. . . . . . . . 96

13. Social Climate Scale Profile - Sonoma County Jail

Male Inmate and Staff. ............

14. Social Climate Scale Profile - Sonoma County Jail

Female Inmate and Staff. . . . . . . . .

15. Social Climate Scale Profile - Salt Lake County Jall Male Inmate and Staff.............

16. Social Climate Scale Profile - Salt Lake County Jail

Female Inmate and Staff. ...........

17. Analysis of Covariance Staff and Inmates Involvement. ................ 
18. Analysis of Covariance Staff and Inmates - Support. .

19. Analysis of Covariance Staff and Inmates Expressiveness ............. . . 104

20. Analysis of Covariance Staff and Inmates - Autonomy - . 105

21. Analysis of Covariance Staff and Inmates - Practical orientation. ................... 106

22. Analysis of Covariance Staff and Inmates - Personal Problem Orientation. ............

23. Analysis of Covariance Staff and Inmates - Order and Organization ............... 108

24. Analysis of Covariance Staff and Inmates - Clarity. . 109

25. Analysis of Covariance Staff and Inmates - Staff Control................... 110

26. Disciplinary Report RBJ-1983/MCDC-1984. . . . . . 
CHAPTER I

THE JAIL AS A SOCIAL REALITY

\section{INTRODUCTION}

There has been a strong movement in recent years to replace outdated and inadequate jails across the United States. According to The State of Our Nation's Jafls - $1982,{ }^{1} 15.9 \%$ of all jalls have been. under a court order at one time or another to improve services or conditions and currently $10.7 \%$ are under similar orders. Certainly this situation has provided fuel for the surge in jall planning and construction, particularly because many communities are unable to effectively deal with the demand for jall services that they are currently experiencing. Approximately 960 out of the 3,493 jails in the United States are 50 or more years old; in the perlod 1979-1982, 408 bond measures were proposed to construct new jails or renovate existing jails. ${ }^{2}$ This increase in planning and construction has given birth to a new area of expertise among architects and contractors - jail design and construction. There are now several firms that specialize in the design and construction of secure facilities such as jails.

While design and construction techniques have improved, little is known of the effects of architecture on the social climate of a jail. This question is part of a larger one, namely, does architecture affect behavior generally? Prohansky et $a .^{3}$ and many others have argued that architecture does indeed influence the behavior of human beings. How- 
ever, little is known of the impact of architecture on jail inmates and staff. In an attempt to answer the question of whether or not the physical plant influenced the social climate of jails, this study seized upon a natural experiment in which an old antiquated jail(Rocky Butte) was replaced by a new, ultra-modern 470 bed high-rise jail(Multnomah County Detention Center). Two working hypotheses were examined in this study:

1) The combined perceptions by inmates of social climate will be higher or more positive in the new jail (MCDC) than in the old one (RBJ), while little or no change in perceptions will be observed in control jalls.

2) The combined perceptions by staff of social climate will be higher or more positive in the new jail (MCDC) than in the old one (RBJ), while little or no change in perceptions will be observed in control jails.

The question of what kind of architectural change affects the social climate of a jail has broad implications with regard to design and construction of jails and other secure facilities. If the answer to this question can be determined, then it may be possible to improve service delivery in local jails, increase staff satisfaction with the work environment of jalls, and improve mental and emotional health of jafl staff and inmates; all of which can be translated into savings to the taxpayer.

\section{ORGANIZATION OF THE STUDY}

In the remainder of this chapter, attention is given first to a brief account of the development of jails in Western societies, particularly in the United States. Chapter 2 provide a detailed review of the theoretical and research work that has explored relationships 
between organizational climate and physical environment and, particularly, between social relations and architectural features.

Chapter 3 reviews the history and architecture of Rocky Butte Jail, its effects on inmates are examined, and some conclusions are drawn regarding the impact of the physical plant on inmates and staff. This jait is then contrasted to the new and ultra-modern Multnomah County Detention Center. The latter's siting, design, and construction is examined, along with the possible impact of these factors on inmates and staff. Finally, both jails are briefly discussed in terms of what is known nationally about jail construction and the present state of the nation's jails.

Chapter 4 briefly sets out the research problem and design and is followed by a chapter dealing with the analysis of the data. Chapter 6 then discusses the implications of the findings in regard to future policy and jail construction, that is, the implications the findings have for future policy makers.

One final note is necessary at this point, namely throughout this study, it is made clear that the architecture of the Multnomah County Detention Center is greatly different from that of Rocky Butte Jail. However, more than simple architecture is involved in the study. A number of changes were made in the move from the old jail to the new one in regard to the total physical environment and the delivery of services to the inmates. Therefore, the reader should keep in mind that the term "architecture" is used as a shorthand descriptor for all the changes that went into the move from Rocky Butte Jafl to the Multnomah County Detention Center. 
THE DEVELOPMENT OF THE JAIL

Jails are well established in the Anglo-American experience, although their origins are somewhat obscure. Ralph $\mathrm{Pugh}^{4}$ noted that, after the invasion, the Normans probably found a number of prisons in England, especially upon royal manors in the south. The invaders added to this number by building many castles in which powerful adversaries, and many of the common people, were locked up. By 1166, jalls similar to those that we are familiar with today made their appearance. The primary purpose of those jails was not only to hold political enemies but also to confine persons accused of crimes until their guilt or innocence could be determined. The Sheriff, as official representative of the King, was responsible for maintaining the gaol (as it is spelled in England).

Jails were usually maintained with little or no regard for the health and welfare of the inmates. Children, prostitutes, hardened criminals, and the mentally $i 11$ were confined in the common dungeon-1ike rooms with sanitation provided by nothing more than an open gutter. In that the failer was usually appointed without salary, each inmate's family was required to pay for food, clothing, and--if the inmate could afford it--luxuries such as gin or the services of a prostitute. Nearly half the local jails or prisons in England in the early 1700s were privately-owned. For example, the Duke of Leeds owned Halifax Prison; Lord Derby owned Macclesfield Prison; the Bishop of Durham owned the County Gaol at Durham, and the Duke of Portland owned Chesterfield gaol, which he rented out for eighteen guineas a year. In a private prison at 
Exeter, there was no chimney, sewer, or water, and the men were chained to the floor on their backs with spiked collars around their necks and heavy iron bars over their legs, unless they were able to pay for removal of the bars. 5 This "easement of irons" was a common practice and was only one of many fees the prisoner had to pay when confined to the gaol.

Not surprisingly, the English jail, like other British institutions, was transplanted to the colonies. Its relocation was complete with county responsiblity, sheriff administration, and fee-for-service type compensation. 6

The first jail on the North American Continent was established in Jamestown, Virginia in 1607 at the time the Virginia colony was founded. In 1642, the General Assembly of Virginia enacted the first legislation authorizing the construction and maintenance of county fails. This model, which included large cells for many prisoners and a fee system, set the pattern usually followed to this day. As other communities were developed on the North American continent, jails were constructed following the form first adopted in Virginia in the mid-1600s. There were no single cells, only rooms to house twenty to thirty prisoners each. The sheriff's fee system was maintained for some time, but was gradually replaced by a complete subsidy by the county government. Today, most jails are under the supervision of the county sheriff who appoints a jail administrator.

According to one recent survey, "the state of our nation's jails can be compared to ships foundering on the beach at low tide." 7 The survey strongly indicated that today's jails are plagued by extensive 
problems of inadequate personnel, lack of modernization, overcrowding, and underfunding. Jails are also busy places. According to the Bureau of Justice Statistics, there are currently 3,493 jail facilities in the United States, holding more than 212,000 people on any given day, and approximately 7 million in the course of a year. ${ }^{8}$ There are an additional 13,566 temporary facilities (lockups) that can hold people for up to 48 hours; these are not included in the foregoing statistics. It is indisputable that many jalls are overcrowded and often unpleasant places in which to work and to be confined. Over the years many knowledgable authorities have advocated less reliance upon jails as a device for assuring the appearance of offenders at their trial.

Mattick and Aikman ${ }^{9}$ as well as Daniel Glaser ${ }^{10}$ have noted that jails represent the segment of corrections most neglected by scholars and the public. Jails have been investigated by social reformers for years, but moral indignation has brought about little change or little interest on the part of sociologists. Jails continue to be ignored, underbudgeted, understaffed, and either under or over utilized. As long as no major scandal erupts, the jail is forgotten and ignored. This is an intolerable state of affairs when one considers that a sizable majority of any jail population is confined on pretrial status and must be presumed to be innocent. Yet, these persons are of ten subjected to brutality and various indignities simply because they may be too poor to afford bail. 11 Mattick ${ }^{12}$ presaged this indictment and pointed out that the jail is the major intake center for the entire criminal justice system. It is also a place of first or last resort for a host of disguised health, welfare, and social problem cases. He lamented the 
fact that so few resources are devoted to jails. Similarly, Irwin ${ }^{13}$ claimed that jails are designed for the purpose of holding and managing the disreputable people in society whose major crime is to be offensive to mainstream citizens.

Early books and articles on jails contained reports of reformers interested primarily in exposing corruption, and called for upgrading the practices and physical facilities so that, at the least, they would be humane and clean. As early as 1873, Benjamin Waugh ${ }^{13}$ described the unpleasant conditions in English gaols and called for reform. In 1923, Joseph Fishman, an early Jail Inspector for the U.S. Department of Justice, confronted his readers with the "unbelievably filthy"15 conditions existing in American jails. Others, including Clarence Darrow ${ }^{16}$ Mattick and Aikman; ${ }^{17}$ and Casey ${ }^{18}$ called for reforms, research, and a general upgrading of facilities and procedures. More recently, other writers have directed our attention to the need for recreation in high-rise jails ${ }^{19}$ and to the mental health needs of prisoners in urban jails. ${ }^{20}$ Smith $^{21}$ provided an assessment of detainee preferences as he observed them in three different jail settings. Using Hans Toch's 22 "Prison Preference Inventory," he determined that among inmates surveyed, soctal support via program opportunities was the most highly preferred factor, with freedom, privacy, feedback, and soctal stimulation following closely. Suicides in jails have also been the object of study by Hays ${ }^{23}$ who has developed a profile of the suicide victim. He provided specific recommendations for jailers, public officials, and legislators that may help alleviate that problem.

Even though the media, reformers, and the courts have taken an 
interest in jails, sociologists have generally ignored them as an object of study. Irwin noted this fact and stated that, "Social scientists, like the general public, have shown a great interest in the prison but have almost completely ignored the jail." 24 other than Irwin's book, a search of the literature reveals few studies on the social organization of the jail. But, perhaps some feeling for the social climate of jails can be derived from the sociological literature dealing with prison social structure.

SOCIAL ORGANIZATION OF THE PRISON AND JAIL

Cressey $^{25}$ beautifully summed up the nature of prison social organization when he stated that any prison is made up of the synchronized actions of hundreds of people. All of them are involved in hating a number of staff and other inmates; respecting and loving others; fighting physically and psychologically; and vying with each other for favors, prestige, power, and money. The amazing thing, he concluded, is that prisons "work." Somehow, the personnel--including prisoners--are bound together in a way that most misunderstandings are not critical. According to Cressey," social organization" is a complex phenomenon with subtle and almost invisible aspects. Organizational charts show the official lines of authority and communication but they often do not hint at the real institutional organization: who has real power or who influences whom.

Even though the social organization of the prison is extraordinarily complex, an extensive literature on this topic has been produced by social scientists who have taken an active interest in the prison. 
Goffman ${ }^{26}$ asserted that the central feature of "total institutions," a major version of which is the prison, can be described as a breakdown of the barriers ordinarily separating sleep, play, and work. He pointed out that all aspects of life are conducted in the same place, under the same authority, and in the company of the same people--all of whom are treated alike. Under tight scheduling, and with all the various forced activities designed to fulfill the official aims of the institution, it can be brought together in a single rational plan. The total institution is also symbolized by barriers to social intercourse with the outside world. Those barriers are often built into the physical plant and include locked doors, barbed wire, and/or isolation.

Goffman also argued that while the inmates bring a culture into the institution with them, once they are admitted and submit to the daily processes that are aimed at managing their daily lives, they are stripped of this support by the processes of mortification and dispossession. Sykes and Messinger ${ }^{27}$ speculated that the prison is characterized by a single value system that dominates the social fabric of the inmates' 1ives. This inmate code advises inmates: "don't interfere with inmate interests" and "don't exploit inmates." Sykes and Messinger's primary argument was that the inmate code is situational, that is, it is a response to the "pains of imprisonment." 28

On the matter of social organization of the prison, sykes 29 observed that the uniqueness of the frustrations imposed on the inmates; or what he called "the pains of imprisonment," as well as their prior training in deviance, results in a social group characterized by a high degree of internal exploitation where "fellow sufferers are scorned as 
powerless victims even more than the custodians are despised as symbols of oppression." 30 Rather than being a community, sykes pointed out that men in prison tend to react as lone individuals and refuse to suspend intramural conflict even when confronting the prison officials.

The social organization of the prison may be governed by an inmate code, but there is also a strong case in support of the argument that much of it is imported from the outside rather than being solely a product of the prison experience. Stanton Wheeler ${ }^{31}$ and George Grosser $^{32}$ have both suggested that the inmate subculture may be imported, that is, brought into the prison by newly-arrived inmates.

Regarding inmate norms in jails, Garafalo and $\mathrm{Clark}^{33}$ have found evidence that positive orientations toward inmate subcultural norms in jail settings are primarily attributable to more experienced inmates who are already familiar with the norms when they enter the jall, and who readapt to these same norms after making a determination that they will not soon be released. More specifically, Garafalo and Clark did not find jails to have full blown inmate subcultures, rather, they are places where socialized carriers of the jail subculture come together periodically to readapt to the norms of the subculture.

Returning to the case of prisons, Cressey and Irwin ${ }^{34}$ identified three Inmate subcultures: a prison subculture, a criminal subculture, and a legitimate subculture. The legitimate subculture and the criminal subculture both involve persons whose in-prison orientation is to life on the outside of prison, while the inmate culture centers around prison social values. For example, inmates oriented to the convict or prison subculture seek positions of power and influence in the prison. A job 
as Captain's Clerk gives great power and influence which can be used to the inmate's advantage. That influence, in turn, can be used to purchase those things which are symbols of status among persons oriented to the convict subculture, including information and such material posessions as "bonaroos," which are specifically tailored and starched prison clothing; unique belts and belt buckles; and special shoes or any other possession which will set the inmate apart from the general population. Thus, these three patterns reflect the different orientations of different groups of prisoners but, more importantly, the three subcultures are evidence of the validity of the importational or diffusionist perspective as an explanation of the make-up of inmate culture and the social organization within the prison.

Other aspects of the social organization of the prison have also been the object of study. For example, studies have also been conducted on guards. Lombardo ${ }^{35}$ found that corrections officers at Auburn Correctional Facility in New York learned their jobs on their own and even from inmates, which is a pattern which contrasts with that of the police who experience a strong apprentice relationship when they first enter the job. He also found that the prison guard attempts to find assignments that accommodate his own needs, "whether he seeks to make the time pass, to control his work environment or help or get away from inmates, the guard's work, as he performs it, is often a reflection of his personal preferences." 36 McCleery found that, "custodial control of communications imposed custodial attitudes, values, and behavior throughout the industrial program of a large maximum security prison, thus negating its formal institutional position and purposes."37 
Cressey ${ }^{38}$ reported that there is no counterpart in the private sector to the prison guard and that most guards have nothing to do except to "guard," that is, they concentrate their efforts on watching others and are not used productively any more than inmates are used productively. In a similar vein, Jacobs ${ }^{39}$ found a highly rational and problem oriented corporate model of prison management which is professionally oriented and detached.

\section{ONE VIEW OF JAILS}

Jails, unlike prisons, have been deplorably ignored. Most books on jails have to do with unsafe and often unhealthy conditions or with jail management. The most definitive soclological treatment on jails is John Irwin's The Jail: Managing the Underclass in American Society. His insights on the social structure of jails, and his ability to graphically depict life in them, has provided by far the most complete description of jall life to date. He argues that:

The public impression is that the jafl holds a collection of dangerous criminals. But familiarity and close inspection reveal that the jall holds only a very few persons who fit the popular conception of a criminal--a predator who seriously threatens the lives and property of ordinary citizens. In fact, the great majority of the persons arrested and held in jail belong to a different social category...the poor...under educated, unemployed, and they belogg to minority groups... 'social refuse,' or 'social junk.'

Irwin has reported that most of the inmates included in his research on the San Francisco County Jail appeared to fit this definition and that the vast majority of people arrested, booked, and held in jail are not charged with serious crimes. Jail inmates are primarily members of the "rabble" class, defined as "persons who are poorly inte- 
grated into the society and who are also seen as disreputable." 41 This definition fits petty "hustlers," derelicts, "junkies," "crazies," and "outlaws." In addition, marginal rabble (such as 1 llegal aliens and homosexuals) are also included with some frequency. Irwin asserted that receiving a jail sentence is more closely related to the offensiveness of the individual than to the seriousness of the crime the person has committed.

However, it is nonetheless true that a certain percentage of the prisoners in any jail are hardened criminals who have been convicted of felonies and are in jail rather than prisons for a variety of reasons, such as being held for trial on charges associated with their original charge or for crimes committed while in prison. The experience of being placed in jafl has some unintended consequences. Irwin observed that going to jail either maintains one's rabble status or converts one to membership in the rabble class. These unintended consequences also Involve three basic dimensions which Irwin identified as loss of property, loss of social ties, and loss of capacity to "take care of business." Loss of property refers to the sequence of events that begin at arrest--when one may fall behind in the rent and lose one's apartment or job and subsequently, one's auto or other time payment articles. Also, the booking process contributes by taking away clothing, money, and other personal articles. These belongings may or may not be returned, depending upon the number of transfers the person experiences or the honesty of the jailers.

Loss of soctal ties refers to the prisoner's Inability to maintain family and friendship ties and obligations. In addition, his or her 
access to the outside world is restricted in spite of the fact that jails are usually required to provide telephone access and writing material to indigents. Finally, the loss of capacity to "take care of business" refers to the prisoner's inability to attend to private affairs, for example, legal matters which, if unattended, result in complications to one's legal status.

Going through the process of arrest, booking, and being placed in jail can have considerable impact on the prisoner's psychological well-being, resulting in a state of disorientation. According to Irwin, when the individual enters the jail he or she begins to experience feelings of malaise, anxiety, disillusionment, and despondency that are often associated with alienation. This results in the individual losing his or her sense of distinctiveness. In addition, one loses a grip on more profound meanings such as values, goals, and conceptions of self. The jail experience stuns the person and impalrs his or her ability to reenter society without difficulty.

The degradation in prisons that is inherent in the intake and orientation process and which also is a part of daily institutional 11fe, is well documented. Irwin has 1llustrated the parallel degradation that accompanies the jail experience. The humfliation begins with the booking process that is characterized by commands, shouting, and threats which follow the individual into the tanks. During intake, the prisoner is issued ill-fitting clothes and once in the tank, not only is personal hygiene a problem, but he or she is subjected to the scrutiny of other prisoners. This process is vividly captured in the movie Straight Time, starring Dustin Hoffman. The leading character, Max 
Denbo, is stripped of his clothes and other personal articles, searched, showered, and deloused in a group with no attempt to preserve personal dignity. As Irwin has put it:

The human density and total lack of privacy exposes them to one another in ways that can occur only in total institutions. They inspect one another's genitals, scars, rashes, and deformities. They smell one another's breath, sweat, gases, and feces. They hear one another's snoring, breaking wind, and masturbating.

Police officers and the deputies also contribute to the continued debasement of prisoners by their attitudes toward them and their belief that disreputables are the cause of most trouble in society. According to Irwin, degradation is built into court routines as well because these are planned and executed to dignify reputability and conversely, condemn dis reputability. This is accomplished, to a degree, by the bailiff ordering those present to stand upon the entrance of the judge and by the judge wearing his or her robe and sitting in an elevated position in the court room. On the other hand, the rabble appear in jumpsuits issued by the jail or clothes in which they were arrested, or at least in attire that is not "a proper court uniform," e.g., T-shirts, denim pants, leather jackets, and high boots.

Irwin concluded his book by expressing the belief that the jail is the "primary socializing institution of the rabble existence" 43 and argued that a social concern ought to be that too many times it successfully converts people into a committed deviant lifestyle. Finally, he suggested a "new agenda" that might indirectly influence jail policy and, thereby, decrease its influence on the rabble class. Irwin's new agenda included concentrating police and penal attention on serious crime, learning to tolerate the rabble, re-establishing informal systems 
for controlling public deviance, and finally, working to alter our basic values so as to move away from excessive materialism and individualism. 44

SUMMARY

Jails are well established institutions in the community. They are taken-for-granted, underfinanced, and only come to the attention of the public if a scandal or a major calamity occurs in them. However, Irwin has called our attention to the fact that they may be a main influence in perpetuating a permanent "jail class" and, if so, they serve to reinforce a commonly held sterotype that "undesirables" are responsible for many problems in the community.

This opening chapter has set the stage for the research reported here, by examining the history of jails in Western societies and also by briefly scrutinizing the literature on the social structure of prisons and jails. Chapter 2 Investigates some of the ways in which architecture may influence the inhabitants of jails, including both staff and prisoners. The chapter begins with a generalized look at architecture and organizational climate and then discusses the specifics of jails and architecture. 
FOOTNOTES

${ }^{1}$ National Sheriff's Association. The State of Our Nation's Jails-1982 (Washington, D.C. 1982).

2 National Sheriff's Association. The State of Our Nation's Jails-1982 (Washington, D.C. 1982).

${ }^{3}$ Harold M. Prohansky, William H. Ittleson, and Leanne G. Rivlen. Environmental Psychology, 2nd ed., eds. (New York: Holt, Rinehart and Winston, 1976). pp. 27-37.

"Ralph B. Pugh. "Imprisonment in Medieval England" (Cambridge, MA: Cambridge, University Press, 1968), in John Irwin, The Jail (Berkeley, CA: University of California Press, 1985). p. 3.

${ }^{5}$ Christopher Hibbert. The Roots of Evil (Boston, MA: Little Brown and Company, 1963). p. 133.

${ }^{6}$ Advisory Commission on Intergovernmental Affairs. Jalls: Intergovernment Dimensions of a Local Problem (Washington, D.C.: 1984). p. 86 .

7 National Sheriff's Association. The State of Our Nation's Jails 1982 (Washington, D.C.: 1982). p. 3 .

${ }^{8}$ Advisory Commission on Intergovernmental Relations. Jails:

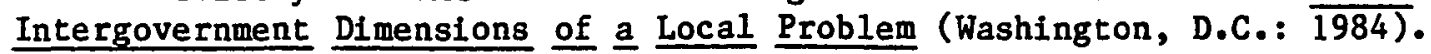
p. 2 .

${ }^{9}$ Hans พ. Mattick and Alexander Aikman, "The Cloacal Region of American Corrections," The Annals of the American Academy of Political and Social Science 381 (January, 1969): Pp. 109-118.

${ }^{10}$ Daniel Glaser, "Some Notes on Urban Jails," in Daniel Glaser ed. Crime in the City (New York: Harper and Row). 1970.

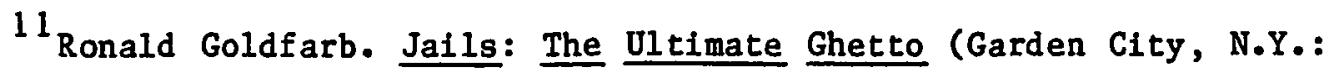
Anchor Press/Doubleday, 1975).

${ }^{12}$ Hans W. Mattick, "The Contemporary Jails of the United States: An Unknown and Neglected Area of Justice," in Daniel Glaser, ed. Handbook of Criminology (Chicago: Rand McNally Publishing Company, 1974).

13 John Irwin. The Jail (Berkeley, CA: University of California Press 1985), p. 23.

14 Benfamin Waugh. The Gaol Cradle: Who Rocks It? (London: Strahan and Co., 1873). 
15 Joseph Fishman. Crucibles of Crime (New York: Cosmopolis Press, N.Y., 1923).

${ }^{16}$ Clarence Darrow. Crime: Its Cause and Treatment (1922; Montclair: Patterson Smith, 1972).

${ }^{17}$ Hans W. Mattick and Alexander Aikman, "The Cloacal Region of American Corrections," The Annals of the American Academy of Political and Social Science 381 (January, 1969): pp. 109-118.

${ }^{18}$ Roy Casey, "Catchall Jails," The Annals of the American Academy of Political and Social Science 293 (May, 1954): pp. 28-34.

19 Winston E. Moore, "Lowdown on High Rise Jails," Parks and Recreation (September, 1974): pp. 39-40.

20 E. Guy, J. Platt, I. Zwerling, and S. Bullock, "Mental Health Status of Prisoners in an Urban Jail," Criminal Justice and Behavior, 12 No. 1 (March, 1985): pp. 29-53.

${ }^{21}$ Dale E. Smith, "Local Corrections, A Profile of Inmate Concerns," Criminal Justice and Behavior 11, No. 1 (March, 1984): pp. 75-99.

22 Hans Toch. Living in Prison: The Ecology of Survival (New York: The Free Press, 1977).

23 Lindsay M. Hayes. "and Darkness Closes In...A National Study of Jail Suicides," Criminal Justice and Behavior 10, No. 4 (December, 1983): pp. 461-484.

24 John Irwin. The Jail, (Berkely, CA: University of California Press, 1985). p. xi.

25 Donald R. Cressey, ed. The Prison: Studies in Institutional Organization and Change (New York: Holt, Rinehart and Winston, Inc., 1961): pp. 1-12.

26 Erving Goffman. "On the Characteristics of Total Institutions: The Inmate World," in Donald R. Cressey, ed. The Prison: Studies in Institutional Organization and Change (New York: Holt, Rinehart and Winston, Inc., 1961).

${ }^{27}$ Gresham M. Sykes and Sheldon L. Messinger, "The Inmate Social System," in Theoretical Studies in Social Organization of the Prison by Richard A Cloward, Donald R. Cressey, George H. Grosser, Richard McCleery, Lloyd E. Ohlin, Gresham M. Sykes, and Sheldon L. Messinger. (New York: Social Science Research Council, 1960). pp. 5-27.

${ }^{28}$ Gresham M. Sykes. The Society of Captives (Princeton, New Jersey: Princeton University Press, 1958). 
${ }^{29}$ Gresham M. Sykes, "Men, Merchants, and Toughs," Social Problems 4, No. 2 (October 1956): pp. 130-137.

${ }^{30}$ Gresham M. Sykes, "Men, Merchants, and Toughs," p. 137.

${ }^{31}$ Stanton Wheeler, "Socialization in Correctional Communities," American Sociological Review 26, No. 5 (October 1961): pp. 697-712.

${ }^{32}$ George H. Grosser, "External Setting and Internal Relations of the Prison," Theoretical Studies in Social Organizations of the Prison by Richard A. Cloward, Donald R. Cressey, George H. Grosser, Richard McCleery, Lloyd E. Ohlin, Gresham M. Sykes, Sheldon L. Messinger (New York: Social Science Research Counc1l, 1960). pp. 130-144.

33 James Garafalo and Richard 0. Clark, "The Inmate Subculture in Jails," (Criminal Justice and Behavior 12, No. 4 (December, 1985): pp. 415-434.

${ }^{34}$ Donald R. Cressey and John Irwin, "Thieves, Convicts, and the Inmate Culture," Social Problems 10, No. 2 (Fall 1962): p. 142.

${ }^{35}$ Lucien X. Lombardo. Guards Imprisoned (New York: Elsevier North Holland, Inc., 1981).

${ }^{36}$ Lombardo, Guards Imprisoned. p. 55.

37 Richard McCleery, "Communication Patterns as Bases of Power," in Theoretical Studies in Social Organization of the Prison by Richard A. Cloward, Donald R. Cressey, George H. Grosser, Richard McCleery, Lloyd E. Ohlin, Gresham M. Sykes, Sheldon L. Messinger (New York: Social Science Research Council, 1960). pp. 39-77.

${ }^{38}$ Donald R. Cressey, "Limitations on Organization of Treatment in the Modern Prison," in Theoretical Studies in Social Organization of the Prison by Richard A.Cloward, Donald R. Cressey, George H. Grosser, Richard McCleery, Lloyd E. Ohlin, Gresham M. Sykes, Sheldon L. Messinger (New York: Social Science Research Council, 1960). pp. 78-110.

39 James Jacobs. Stateville: The Penitentiary in Mass Society (Chicago: University of Chicago Press, 1977).

40 John Irwin. The Jail (Berkeley, CA: University of California Press, 1985). p. 1 .

41 John Irwin, The Jail. pp. 40-41.

42 John Irwin, The Jail. p. 73.

${ }^{43}$ John Irwin, The Jail. p. 98.

${ }^{44}$ John Irwin, The Jail. p. 117 . 
CHAPTER II

JAILS, ARCHITECTURE, AND SOCIAL CLIMATE

\section{INTRODUCTION}

This study focuses on the social climate of $j$ ails and the question of whether architecture has an influence on organizational climate and structure. One may be on solid ground arguing that different architectural approaches produce different kinds of behavior and that dark, unkempt, crowded structures produce one kind and light, clean and relatively uncrowded structures produce another type of behavior altogether.

In this chapter, the research and literature related to prisons, architecture, and organizational climate is extensively reviewed. Accordingly, the chapter summarizes and describes research in the field of correctional architecture as a background to the study reported here.

\section{ENVIRONMENTAL INFLUENCE ON BEHAVIOR}

Human beings have constructed shelters almost since the beginning of the species, but it has been only recently that attention has been directed to the question of the impact of the built environment on human behavior. Prohansky et al., 1 have asserted that the constructed physical environment is as much a social phenomenon as a physical one. Additionally, the constructed world, be it a school, hospital, highrise 
office bullding, a jail or prison, is a particular expression of the social system that generally influences our activities and social relationships. That is, in any given society the architecture reflects other, broader cultural forces.

Some criticisms of the intentions of designers have been described. Lange et al., ${ }^{2}$ for example, observed that there has been strong dissatisfaction expressed by the public and users with many bulldings and with the architectural philosophy that has produced them. Craik, ${ }^{3}$ on the other hand, has indicated that architects have always claimed to be designing for people and are interested in designing an environment that can "uplift the spirit and enhance the sense of we1l-being."

The built environment is not simply the artful expression of an architect or designer attempting to "uplift the spirit" nor is it simply an answer to physical needs of human beings, rather, it is a complex phenomenon. Pomeranz ${ }^{4}$ has provided a useful categorization of elements in the built environment, which also appear to be the categories that researchers often use in attempts to understand the impact of the built envi ronment on human behavior.

While there are some overlapping elements, the four areas Pomeranz identified give some meaning to attempts to define the built environment. Since this study is not a technical analysis of architecture, a detailed discussion of Pomeranz's work is unnecessary, but it is helpful to view the built environment as divided into 1) fixed feature variables, that is large, relatively permanent features such as buildings; 2) semi-fixed feature variables, defined as furniture, movable walls, and so forth; 3) ambiant feature variables, defined as 
those objective, but less palpable items such as lighting, color, room temperature, etc. Pomeranz's fourth element has the most salience for this study. That is an area he did not name but identified as having to do with such features as organization climate and structure; the relative size of institutions, organizations, etc., as well as the social and cultural atmosphere and the purposes and goals of institutions and organizations.

There have been two research approaches to measuring organizational properties such as climates. The subjective approach can be referred to as the psychological or process one in which responses are collected from individual members of an organization and then aggregated to yield a measure of the organization. The second, which is an objective approach, can be referred to as the organizational or structural one, in which organizational level information is taken from organizational records. Most research appears to have relied on the subjective or objective approach alone, although there have been some exceptions that attempt to organize the 1iterature. (See James \& Jones, 5 Jones \& James, ${ }^{6}$ Lincoln \& Zeitz, ${ }^{7} \&$ Zeitz. $)^{8}$

INDIVIDUAL RESPONSES

As previously pointed out, the built environment is a complex phenomenon. There is little doubt, however, that the design of buildings has important effects on human perceptions, cognitions, emotions, and behavior. These relationships have been the subject of numerous studies. However, according to Pomeranz, many of those studies have been poorly designed, have addressed trivial questions, and have left many important questions unanswered. In 1972, Stokols ${ }^{10}$ called 
attention to the fact that although behaviorally-oriented investigations have been conducted, the early studies focused mainly on the perceptions and evaluations of individuals regarding a particular built environment. Further, he pointed out that crowding is a function of the relative intensity of spatial, social and personal factors and the degree to which they can be modified. In other words, density precedes crowding, but one can live in a high density environment and not perceive it as being crowded. A more recent series of studies by Baum and Valins ${ }^{11}$ has demonstrated the broad affects of architectural design on diverse aspects of occupant behavior. These impacts range from feelings of being crowded to effects on friendship patterns, room usage, avoidance of social interactions, and performance on a variety of tasks.

The physical environment has a significant impact on levels of stress and on behaviors of individuals. Schorr's ${ }^{12}$ study of slum housing showed that exposure to physical hardships due to inadequate shelter, lack of hygiene facillties, and lack of space for sleeping and child rearing sapped the energy and health of slum occupants, thus it was extremely difficult for them to act alone or as a group to Improve their situation. Dilapidated conditions may contribute to lower levels of self esteem and trust of others.

These brief comments about the study of environmental influences on behavior set the stage for a consideration of what is known about organizational climate and its relationship to variations in the functioning of jails and prisons. 
ORGANIZATIONAL CLIMATE

According to Zohar, ${ }^{13}$ any organization creates a number of
different climates, thus the term "organizational climate" should be
supplemented by an appropriate adjective indicating which type is being discussed. For example, Schneider, Parkington and Burton's" 14 "service climate" or political climate, or Zohar's "safety climate,"15 or the term "political climate" serve to sensitize the reader or listener to the matter under consideration. However, the meaning of the terms, organizational climate or social climate, are difficult to pinpoint.

Some uses refer variously to attitudes of those in power or the generalized attitudes of a group or community. For example, the German concept of "gemeinschaftsgeist" refers to an intellectual climate that acknowledges discoveries or movements. Douglas McGregor ${ }^{16}$ reported that, "many subtle behavioral manifestations of managerial attitude create what is often referred to as the 'psychological climate' of [a] relationship." These two examples indicate that the term organizational climate has widely disparate meanings, however, each time it is used it refers to some feature or characteristic of the environment that has consequences for human behavior and to which the person or group is sensitive.

Renato Tagiuri has provided perhaps the best definition of organizational climate. 17 In his article, he related the term "organizational climate" to the concept of climate as it refers to weather. He began by stating that, while the term climate is often used in lay literature, this is not adequate justification for its adoption for 
systematic purposes. He observed that the term is used for a particular purpose, but "far from obvious is its differentiation from other common terms referring to what surrounds the individual, such as environment, ecology, milieu, culture, atmosphere, situation, field setting, behavior setting, [and other] conditions."18

The term, climate, has a Greek root that means slope or inclination. As Tagiuri pointed out, slope then referred to the slope of the earth and, hence, a region or zone of the earth. Eventually, the term came to mean "the composite or generally prevalling weather conditions of a region, such as temperature, air pressure, humidity, precipitation, sunshine, cloudiness and winds throughout the year averaged over a series of years." 19 Meteorologically speaking, climate is made up of wainy variables, all of which are averaged. When the term is used by meteorologists, it refers simultaneously to various atmospheric features and to a typical series of events. Climate is also described numerically in terms of temperature, humidity, winds, air pressure, and other variables.

Tagiuri has proposed that, "for the purposes of accounting for the behavior of individuals and groups, climate may be useful as a concept that stands between the broadest concept of environment and field, situations or conditions...it is roughly at the same level as ecology, milieu, culture, social system, and atmosphere."20

Tagiuri conceived of organizational climate as:

A relatively enduring quality of the internal environment of an organization that (a) is experienced by its members, (b) influences their behavior, and (c) can be described in terms of the values of a particular set of characteristics (or attributes) of the organization. 
Schnelder's ${ }^{22}$ proposal (that the term organizational climate should describe an area of research) has merit. If one accepts Tagiuri's definition of organizational climate, then one needs to examine the multiple variables that comprise organizational climate. Moos ${ }^{23}$ has pointed out that there is great importance in the setting and the interaction of the individual with the setting and that this is what creates a social climate. Moos's Correctional Institutions Environment Scale deals with many variables as they make up a social climate and is consistent with Tagiuri's definition of organizational climate. As a consequence, the terms organizational climate and social climate will be used interchangeably in this study.

Interaction between physical, psychological, and social elements combine to create an organizational climate. These events are filtered through the perceptual lens of individual organizational members, resulting in many environmental climates. Indeed, Schneider ${ }^{24}$ has suggested that an organization contains as many climates as it has meaningful combinations of interactive elements.

A number of studies of architecture and perceptions of social climate have been conducted, mainly in student dorms. In Corbett's 25 study of student housing, she found that suites are not a uniform solution to social and residential problems. They do, however, afford their residents more privacy than corridor-type rooms while at the same time intensifying problems in coordination in the suite group.

Valins and Baum ${ }^{26}$ found differences in cooperative and competitive behavior and in relations with strangers in dormitories they studied. Crowding in a dormitory setting is related to increased stress along 
with decreased social contact between corridor type and suite residents. Bickman et al., ${ }^{27}$ investigated overall density and found less positive social behavior and group cooperation in high-rise student housing as opposed to low-rise dormitories. Eoyang ${ }^{28}$ pointed out that inhabitants of a student trailer park had a more negative rating of their living space when crowded conditions exist.

Prohansky et al. ${ }^{29}$ have asserted that characteristic patterns of behavior are associated with particular architectural settings. They also reported that these activity patterns are consistent and enduring over time, regardiess of the particular persons in the setting, most of whom are usually unaware of the environmental influences playing upon them.

ORGANIZATIONAL SOCIAL CLIMATE

IN CORRECTIONAL INSTITUTIONS

The studies mentioned above were all conducted on college campuses. But, organizational social climates of correctional facilities have also been studied.

Street, Vinter, and Perrow ${ }^{30}$ examined six institutions and found marked differences in organizational styles among them in terms of dally procedures, long range policies, and in how they developed internal strategies for institutional issues such as custody, treatment, and maintenance. In addition, each institution was markedly different in the manner in which it dealt with external pressure from the communfty or legislature or both. Street et al. also indicated that these differences gave rise to varying staff perspectives and relationships 
between staff and inmates as well as variations in solidarity and attitudes among the inmates. Even more important was the fact that differences in organizational structure appeared to override the individual characteristics of the inmates, that is, even though the institutions differed from each other in terms of the kinds of inmates they held, the organizational variations among them were more significant than were the compositional differences.

As a part of Street, Vinter, and Perrow's larger study, Zald 31 examined the interpersonal relations between staff, between inmates, and between staff and inmates in juvenile correctional institutions. Regarding staff-staff relations, he found a bifurcation along professional/non-professional lines, with educational level being the key factor separating the two groups. The college educated portion of the staff tended to be well-trained, middle-class, and professionallyoriented while the other group was poorly-trained, with little education, and from lower-class origins. Zald concluded that status distinctions may lead to restricted communication between groups, turning each into a closed social unit.

Regarding staff-inmate relations, Zald found some pecularities that set juvenile institutions apart from other bureaucratic organizations: (1) wards and staff formed a community, that is, relationships tend to be continuous and more intimate; (2) the inmates were typically drawn from lower social class backgrounds and were social deviates; (3) staff were in a clearly superordinate position in relation to wards; and (4) adult and adolescent subcultures were markedly divergent. Additionally, some staff formed warm relationships with some boys while forming 
no ties at all with other youths. This is in contrast to other organizations in the private sector, in which relationships between low-ranked members and higher ranking members tend toward neutrality and specificity.

According to $\mathrm{Zald}$, "the incoming delinquent is dependent upon other offenders and staff for all social gratifications and deprivations, and for many definitions of social reality." ${ }^{32}$ As a consequence, other wards served as the primary socializing agent to organizational practices and perspectives. In order to avold perpetual crises in such an organization, staff must reach a "modus vivendi" with the ward leadership and a compromise is reached by "selling" them prerogatives, positions, and psychological rewards. What staff "sells" to the ward leadership influences the ranking criteria within the organization and the structure of the ward social organization.

Zald found that as a consequence of staff attempting to avoid perpetual crises, inmate-inmate relations were heavily affected by staff actions such as: (1) introducing inconsistencies into the relationship, (2) allowing wards to play off one staff group against another, and (3) by presenting the inmate group with an unstable situation.

Street 33 questioned the "solidary opposition" model of the inmate group and the implicit view that training schools are all virtually identical. He conducted an analysis of variations in organizational goals and examined the data provided by inmates of several juvenile correctional facilities. He belleved that researchers have been insensitive to the question: "Under what circumstances do the members of an organization collectively become committed to or alienated from the 
official objectives of the organization?" By stressing the impact of deprivation and degradation on the inmates, researchers have developed the hypothesis: "The inmate group serves the function of alleviating its members' deprivation and degradation." However, Street believes that researchers have not gone far enough and that they should have inquired into "the varying levels of deprivation [and] analyzed the conditions necessary to stimulate, permit and sustain the successful use of such a group solution to the problems of deprivation." 34 He found that the inmates in treatment-oriented institutions had more positive norms and perspectives on the institution and staff and a higher level of primary relations while the attitudes of the leaders toward the institution were also more positive than those of persons in custodial-oriented institutions.

Moos has taken a different approach to investigating organizational social climates in correctional facilities. He stated that the "social climate perspective assumes that environments have unique 'personalities' just like people." 35 Moos's purpose was to develop a way of assessing the social climate of correctional programs by asking residents and staff individually about the usual patterns of behavior in their programs.

As Irwin observed, and as the literature cited in the above discussion shows, correctional institutions have been subject of many studies while jails have generally been ignored. That is, a few notable studies have been conducted on the social climate of jalls. Our attention now turns those studies. 
JAILS AND SOCIAL CLIMATE

It was not until the 1970 s that researchers began to examine the organizational or social climates of jails. Even now, research is limited, but what is available reflects a growing interest in this particular area of study. Richard Wener, a leader in this area, in his research on the Federal Bureau of Prison's Metropolitan Correctional Centers in New York, Chicago, and San Diego, covered a good deal of territory that hitherto had been terra incognito.

In their report on the Chicago Metropolitan Correctional Center and the New York Metropolitan Correction Center, Wener and Clark ${ }^{36}$ found that privacy in both MCC's was considered by inmates to be superior to other institutions in the U.S. Bureau of Prisons. Among inmates in single rooms at the New York MCC, $43 \%$ indicated that privacy was the best feature of the environment. Inmates appreciated the ability to go to their rooms and be alone, and behavioral mapping indicated that the bedrooms (cells) were the most frequently used areas in the institution. By contrast, dormitories were a less frequently used area of the Institution. Inmates in them complained that there was no place to escape from the sight of other residents. An increase in tension and discomfort was noted in those areas, and inmates frequently alleged that the lack of privacy was at the root of these complaints. In the New York MCC, hallways were often used as private meeting spaces for three or four inmates.

Wener and Clark also found that vandalism and graffits was nearly nonexistent in both MCC's, which they attributed to the "soft environ- 
ment" and the opportunity for privacy. Thus, inmates "owned" an area and were careful not to destroy it. Finally, they found that both facilities sometimes exceeded design capacity. When this occurred, perceived discomfort and sick calls increased. In all, inmates perceived these two "new generation" jails to be superior to other institutions. Noise and its impact in jalls has been investigated as well. Gusten $^{37}$ measured noise levels in several sections of the Manhattan House of Detention (The Tombs) prior to renovation. He found noise levels of between 75 and 94 DBA. Even with television sets turned off, the average noise level was measured at 80 DBA. Normal conversation can take place at eight feet, if background noise is at 55 DBA or lower. Wener and $\mathrm{Clark}^{38}$ found the noise levels to be considerably lower in the living areas of the Chicago MCC than in The Tombs.

Correctional environments have many features that intensify the effects of crowding. Paulus et al. ${ }^{39}$ observed that inmates in dormitories displayed considerably more negative affect and had a greater desire for privacy than did inmates in cells holding one or two other occupants. After administering the Criterion of Overcrowding Test (COT) to 142 inmate volunteers at the Federal Correctional Institution at Texarkana, Texas, they concluded that living under relatively crowded housing conditions in a prison produces both negative affect and a lower perception threshold of what constitutes overcrowding.

Wener and Keys ${ }^{40}$ found that relatively small increases in population in a one and two person cell unit, caused by double or triple bunking, for example, precipitated significant increases in perceived crowding and in the rate of sick calls. On a similar note, Irwin ${ }^{41}$ also 
reported that the lack of privacy in jails is degrading and observed that most activities, including bathing, defecating, and sleeping, take place in a crowd.

The organizational social climate of correctional facilities has been the object of study. However, researchers have not attended to the questions of architecture and its link to behavior and perceptions of social climate in correctional facilities. The only exceptions are the user assessment studies in the U.S. Bureau of Prisons Metropolitan Correctional Centers in New York and Chicago. Clearly, this question needs to be probed in order to aid architects and jail planners in the future.

IMPORTANCE OF THE STUDY

This investigation of jails and organizational and environmental influences was undertaken for several reasons. First, with many communities contemplating the replacement of their jails, it was hoped that the study would generate information useful in regard to jall design and appearance. For example, research of this kind might discover that if details such as density of inmate population relative to semi-fixed feature variables and ambient feature variables are attended to, then elaborate, expensive structures may not be necessary. Secondly, information on the perceptions of staff and inmates about the social climate of jails may be found to be useful in jail planning. Finally, the present study was undertaken in order to provide a guide to the future and to impart information to policy makers on some of the factors to consider 
when contemplating a new jail.

SUMMARY

This chapter, has reviewed relevant research concerning architecture and organizational climate in general and how they relate to jails. The built environment is a complex phenomenon and does apparently affect behavior and perceptions of social climate. Any organization creates a number of climates, but the concept of climate has often been misused or misinterpreted.

One of the most useful discussions regarding organizational climate was by Renato Taguiri who defined organizational climate as being relatively intangible but also as something that is experienced by people in that it influences their behavior. It is the organizational climate, or social climate, that researchers have believed to have an impact on inmates' perceptions in prisons and other custodial institutions. However, it has been only recently that researchers have turned their attention to social relations in jails. The "new generation" jails (MCC's) of the U.S. Bureau of Prisons have demonstrated that concern for the users of a jail, that is staff, inmates, and visitors, results in more positive perceptions of social climate and accordingly, more positive behavior.

Attention now turns to the old Multnomah County Jail (Rocky Butte) and the new Multnomah County Detention Center. The descriptions to follow are designed to give the reader some detailed flavor of the old jail and the architecturally different one that has replaced it. 
FOOTNOTES

${ }^{1}$ Harold M. Prohansky, William H. Ittelson, and Leanne G. Rivlen, Environmental Psychology. 2nd ed., eds. (New York: Holt, Rinehart and Winston, 1976). p. 5 .

2 Allen Lange, Charles Burnette, Roland McLaskey, David Vashon, eds. Designing for Human Behavior: Architecture and the Behavioral Sciences (Stroudsburg, PA.: Dowden, Hutchinson, and Ross, Inc., 1974).

${ }^{3}$ Kenneth H. Craik, "Environmental Psychology," in New Directions in Psychology. No. 4 (New York: Holt, Rinehart and Winston, 1970). p. 25 .

"David Pomeranz, "Environmental Psychology," in Environmental Design and Human Behavior. Leonard Krasner, ed. (New York: Pergamon Press, 1980). Pp. 128-157.

${ }^{5}$ Lawrence P. James and Allen P. Jones, "Organizational Structure: A Review of Structural Dimensions and Their Conceptual Relationships with Individual Attitudes and Behavior," Organizational Behavior and Human Performance. 16, No. 1 (June, 1976): pp. 74-113.

${ }^{6}$ Allen P. Jones and Lawrence R. James, "Psychological Climate: Dimensions and Relationships of Individual and Aggregated Work Environment Perceptions," Organizational Behavior and Human Performance 23, No. 2 (Apri1, 1979): pp. 201-250.

7 James R. Lincoln and Gerald Zeitz, "Organizational Properties from Aggregated Data: Separating Individual and Structural Effects," American Sociological Review 45, No. 3 (June, 1980): pp. 391-400.

${ }^{8}$ Gerald Zeltz, "Structural and Individual Determinants of Organizational Morale and Satisfaction," Social Forces 61, No. 4 (June, 1983): pp. 1089-1108.

9 David Pomeranz, "Environmental Psychology," in Environmental Design and Human Behavior. Leonard Krasner, ed. (New York: Pergeman Press, 1980).

${ }^{10}$ Daniel Stokols, "On the Distinctions Between Density and Crowding: Implications for Future Research," Psychological Review 79, No. 3 (May 1972): pp. 275-277.

${ }^{11}$ Andrew Baum and Stuart Valins. Architecture and Social Behavior: Psychological Studies of Social Density (Hillsdale: Lawrence Erlbaum Associates, Publishers, 1977).

${ }^{12}$ Susan Salgert, "Stress-Inducing and Reducing Qualities of Environments," in Environmental Psychology, Harold M. Prohansky, William H. Ittleson, and Leone G. Riviln, 2nd ed., eds. (New York: Holt, Rinehart and Winston, 1976). p. 218. 
13 Dov Zohar, "Safety Climate in Industrial Organizations: Theoretical and Applied Implications," Journal of Applied Psychology 65, No. 1 (February 1980): pp. 96-102.

${ }^{14}$ Benjamin Schneider, John J. Parkington, and Virginia M. Burton, "Employee and Customer Perception of Service in Banks," Administrative Science Quarterly 25, No. 2 (June 1980): pp. 252-267.

15 Dov Zohar, "Safety Climate in Industrial organization: Theoretical and Applied Implications," pp. 96-102.

${ }^{16}$ Douglas McGregor, "The Human Side of Enterprise," in Organizational C1imate: Explorations of a New Concept (Cambridge: Harvard University Press, 1968). p. 26.

17 Renato Tagiuri, Organizational Climate: Explorations of a New Concept (Cambridge: Harvard University Press, 1968).

18 Renato Tagiuri, Organizational Climate. p. 16 .

19 Random House Dictionary of the English Language, Jess Stein, Editor-in-Chief (Random House, 1971).

${ }^{20}$ Renato Tagiuri, Organizational Climate.

21 Renato Tagiuri, Organizational Climate p. 27.

22 Benjamin Schneider, "Organizational Climates: An Essay," Personnel Psychology 28, No.4 (Winter 1975): pp. 447-479.

23 Rudolf Moos. Evaluating Correctional and Community Settings (New York: John Wiley and Sons, 1975).

24 Benjamin Schneider, "Organizational Climates: An Essay," Personnel Psychology 28 (March 1975): pp. 447-479.

25 Judith A. Corbett, "Are Suites the Answer?", Environment and Behavior 5, No. 4 (December 1973): pp. 421-439.

${ }^{26}$ Stuart Valins and Andrew Baum, "Residential Group Size, Social Interactions, and Crowding," Environment and Behavior 5, No. 4 (December 1973): pp. 421-439.

${ }^{27}$ Leonard Bickman, Alan Teger, Thomasina Gabriele, Carl McLaughlin, Mark Berger, and Earl Sunaday, "Dormitory Density and Helping Behavior," Environment and Behavior 5, No. 4 (December 1973).

${ }^{28}$ Carson K. Eoyang, "Effects of Group Size and Privacy in Residential Crowding," Journal of Personality and Social Psychology 30, No. 3 (September 1974): pp. 389-392.

${ }^{29}$ Prohansky et al., Environmental Psychology, 1976. 
${ }^{30}$ David Street, Robert D. Vinter, and Charles Perrow. Organization for Treatment (New York: The Free Press, A Division of the MacMillan Company, 1966).

${ }^{31}$ Meyer N. Zald, "The Correctional Institution for Juvenile offenders: An Analysis of Organizational Character," Social Problems 8, No. 1 (Summer 1960): pp. 57-67.

${ }^{32}$ Meyer N. Zald, "The Correctional Institution for Juvenile offenders: An Analysis of Organizational Character,": p. 61 .

${ }^{33}$ David Street, "The Inmate Group in Custodial and Treatment Settings," American Sociological Review 30, No. 1 (February 1965):

pp. 40-55.

34 David Street, "The Inmate Group in Custodial and Treatment Settings,": p. 43.

${ }^{35}$ Rudolf Moos. Evaluating Correctional and Community Settings (New York: John Wiley and Sons, 1975). p. 4.

${ }^{36}$ Richard E. Wener and N. Clark, "Innovative Correction Environment," Environment and Behavior 12, No. 4 (December 1980): pp. 478-493.

${ }^{37}$ R. Gusten, Noise in Jails: The Constitutional Issues (Washington, D.C.: National Clearing House for Criminal Justice Planning and Architecture, 1977).

${ }^{38}$ Richard E. Wener and N. Clark, User Based Assessment of the Chicago Metropolitan Correctional Center, Unpublished report to the U.S. Bureau of Prisons, 1976 .

${ }^{39}$ P. Paulus, V. Cox, G. McCain, and H. Chandler, "Some Effects of Crowding in a Prison Envi ronment," Journal of Applied Social Psychology 5, No. 1 (January 1975): pp. 86-91.

${ }^{40}$ Richard Wener and C. Keys, Non-Density Factors and the Perception of Crowding, submitted to the American Psychological Association, 1979.

41 John Irwin, The Ja1l. 
Chapter III

\title{
A HISTORICAL AND DESCRIPTIVE OVERVIEH OF THE MULTNOMAH COUNTY JAIL SYSTEM AND THE NEW MULTNOMAH COUNTY DETENTION CENTER
}

\begin{abstract}
To adequately portray Rocky Butte Jail, its place in the total Multnomah County Ja1l system must be described. Until 1983, the Department of Justice Services operated four jail facilities in Multnomah County: the Court House Jail (CHJ), Rocky Butte Jail (RBJ), Claire Argow Women's Detention Center ( $\mathrm{CAC}$ ), and the Multnomah County Correctional Institution (MCCI).
\end{abstract}

SYSTEM OVERVIEW

COURT HOUSE JAIL

Prior to 1947 , the Court House Jail was the only county jail and was located on the top floor of the Multnomah County Building and Courthouse. After the construction of RBJ in 1947, the Courthouse Jail was used primarily for booking and for holding people who were scheduled for trial on any given day. In addition, it served as the reception point for civil holds, short term holding after booking, and a place to which inmates were transferred if they were to be interviewed by an attorney or make an appearance in court. There was a very high volume of traffic in and out of the CHJ every day and it was a noisy, confusing place. By Monday morning, following the weekend, it was often exceed- 
ingly crowded and confused because no transfers were made to RBJ until Monday morning. During the course of administering questionnaires, inmates related stories of rapes and assaults on a regular basis in the Court House Jail. "There was simply too much for the guards to do and supervising the cells was not high on the 1ist," stated one prisoner, "besides, the guards wouldn't even come into the cells to break up a fight." These type of incidents were subsequently verified by others who had spent time in the Court House Jail.

As noted above, the CHJ which was located on the seventh floor of the court house and also contained a women's holding tank on the efghth floor. The jail was staffed by 30 men and six women with seven court security personnel being accounted for in the CHJ budget in 1983. The general physical lay-out of the Court House Jail was in the shape of an "L" which in effect 1 imited or prevented desirable separation of inmates or even safe movement of prisoners from one area to another. All persons brought to the facillty by the police gained access to the jail elevator by using the first floor public corridor of the court house. Due to the high population turnover, the Court House Jail was difficult to keep clean; the food, while rutritious and wholesome, was of ten bland and sometimes cold; and oftenilmes the tanks were unsafe because of the inability of staff to separate combatants or persons with emotional problems.

ROCKY BUTTE JAIL (RBJ)

Until 1983, RBJ was the major facility for housing males in Multnomah County. It consisted of four bulldings surrounding a court yard, with a recreation field on the northwest corner. Historically, it 
was used as a place to hold both sentenced and unsentenced prisoners; that is, as a place for misdemeanants and class $C$ felons to serve sentences, as a pre-trial detention facility, and also as a place of secure confinement for those being held for other counties, states, and federal authorities. Until 1972, women were also confined at RBJ. However, in 1972, Claire Argow Center for Women was opened, thus creating more bed space for men at RBJ. The operation of RBJ was a complex and difficult task Involving 64 corrections officers, the commander, four food service workers, an investigator, five administrative staff persons, and the equivalent of several workers on an on-call basis. The overall inmate capacity was rated at 320 , however, this figure was exceeded many times throughout the history of Rocky Butte Jail.

MULTNOMAH COUNTY CORRECTIONAL INSTITUTION (MCCI)

The MCCI is primarily a work and education release facility staffed on a 24-hour basis by 11 corrections of ficers, three fail stewards, and two clerical administrative personnel. In the last several years, however, the mission of MCCI was broadened in scope in order to include people serving sentences but not eligible for work or educational programs in the community. Its normal capacity is 155 inmates, with programs offered including work release, education release, and several in-house programs. Overcrowding has always been a problem at MCCI and the social pass program plays an essential role in maintaining the population of the facility at 155 inmates. Often in the past inmates who have served some time at the facility have been given a weekend pass simply to create a bed for a new arrival or a person serving a weekend 
sentence. Upon their return, they would either be accepted back into the institution or be placed on pass again.

The MCCI consists of a control center with three wings radiating out from the control center as spokes on a wheel. One of the wings is devoted to housing 75 inmates while 80 inmates are in another wing. The third wing is devoted to recreation, counselor's office, library, and space for programs. MCCI is a minimum security facility with no guard towers or high fences around it. CLAIRE ARGOW CENTER (CAC)

Claire Argow Center was used exclusively for secure confinement of women. Almost all women lodged at CAC had been transferred there from the Court House Jall, and the majority of those transferred to CAC were originally arrested by the Portland Police Bureau or the Multnomah County Sheriff's Department. CAC was a secure facility that was converted from a vacant wing of the local juvenile detention facility. Rated capacity was 55 women who were housed in two wings placed adjacent to a control center from which both sections could be viewed simultaneously. In addition, there was space for a day room, kitchen, and programs. Unlike the men's facility, Claire Argow Center was rather pleasant, had a sense of homeyness, and the staff members were more relaxed and agreeable than at any of the factlities for men. The women prisoners were allowed to wear their personal clothing, there were curtains on the windows and the floors were always clean. Since 1985 CAC has been closed, reopened and closed a second time. It does not appear that CAC will be opened again. 
HALFWAY HOUSE FACILITIES

At the time of this study, 1985-1986, the county had also contracted with three local community residential programs (for a total of 48 beds) for prisoners nearing the end of their sentences. Criteria for referral to one of these facilities included being within three months of release, having no record of institutional management problems, and having no history of violence. There is bed space for twenty-three women and twenty-five men in the three facilities. The three residential programs serve both the innercity and the populous eastern portion of the county.

As one can see from the preceeding descriptions, Multnomah County's jall system had its strong points such as a minimum custody facility, a separate booking facility, and community programs. The weak points of the system included unplanned growth, overcrowding, and poor security features in both the CHJ and the RBJ. With this background, a detailed examination of RBJ is presented next.

\section{ROCKY BUTTE JAIL}

The following discussion of Rocky Butte Jail draws heavily upon the author's experience as Assistant Director of Justice Services for Multnomah County. It includes a physical description of the jail, along with an attempt to give the reader a subjective feeling of the jail. The subjective description is necessary in order to gain some respect for the unpleasantness as well as the inadequacy of the total facility. According to one former inmate, drugs were extremely easy to 
smuggle into the fail. In fact, he stated that most drugs entered RBJ via the Court House jail and that shakedown procedures were so poor that marijuana and cocaine were simply stuffed in one's sock or underwear. Once in the tank and sold or distributed, the smell of the marijuana was masked by the general smell of the tank.

Another inmate remarked about the ease with which more predatory inmates could sexually exploit younger and more intimidated prisuners. He specifically told the story of a "young boy" who was arrested in Gresham with an older exconvict. The older man told the boy that he would look out for him. "I could tell the boy was scared so he just went along with the exconvict." While they were in the CHJ, the exconvict managed to be assigned to a seldom supervised cell at the back of the range with the younger prisoner. There, the former inmate remarked, "the older guy just had his way with him."

This is not a problem that was unique to Rocky Butte jail. Davis ${ }^{1}$ studied the aggressors and victims of sexual assault in the Philadelphia prison system and found that in the twenty-six month study period, 156 sexual assaults occurred that could be documented. He believed that the number was actually much higher, but the incidents went unreported for various reasons such as fear of retaliation.

Another man who had spent a good deal of time in RBJ related the story of a young first offender who had been an inmate at MCCI. The latter had fractured his ankle during a softball game. Instead of repairing his ankle and returning him to $M C C I$, he was kept in the D tank of RBJ. There he was "befriended" by a rather sophisticated drug addict. During the young man's stay, one of his family members died and 
the inmate was approved for a twelve hour unescorted furlough to attend the funeral. His new "friend" persuaded him to meet his wife and pick-up a "works" and some heroin. "The boy then stuck both the 'works' and the heroin up his butt and brought it into the jail and the guards didn't even find it. All he did when he got into the tank was go into the shower, squat down and out popped everything."

The consensus of opinion from Grand Jury members, jail staff, and county commissioners was that RBJ was unsafe, dirty, and in poor repair. Figure 1 gives anovrallfloor plan and the following descriptions more vividly detail what life was like in the jall.

Figure 1

GENERAL LAYOUT RBJ

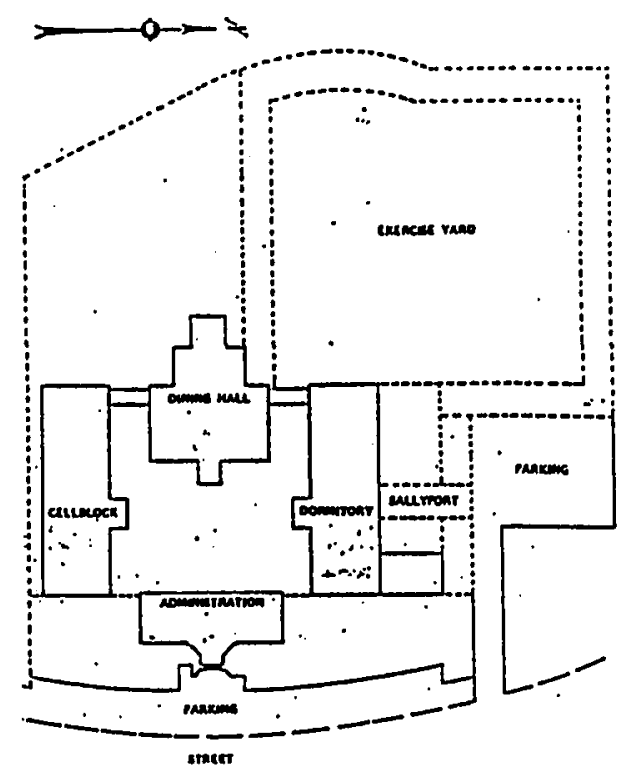




\section{A TANK}

This was one of two identical units, each having 2,236 square feet of floor space, located on the top floor of the north building. The unit was subdivided into 13 four-person cells, a single occupancy cell at the west end, an enclosed walkway for prisoners, and an external walkway for the cell house officer. It contained a shower and washroom at the east end of the prisoner walkway, and each cell contained one wash bowl and toilet. The layout of the cells, walkways, and Iiving space is shown on the floor plan below. A review of Figure 2 gives the reader some indication that there was little interaction between the correctional officer and occupants of the tank. The officer's work station was outside of the tank and he was required to periodically walk around the tank in the catwalk but the truth is that it was a chore that was avolded if possible. Furthermore, standing orders specified that an officer who witnessed an assault was prohibited from entering the tank until assistance could be on hand.

\section{Figure 2}

\section{A \& B TANKS}

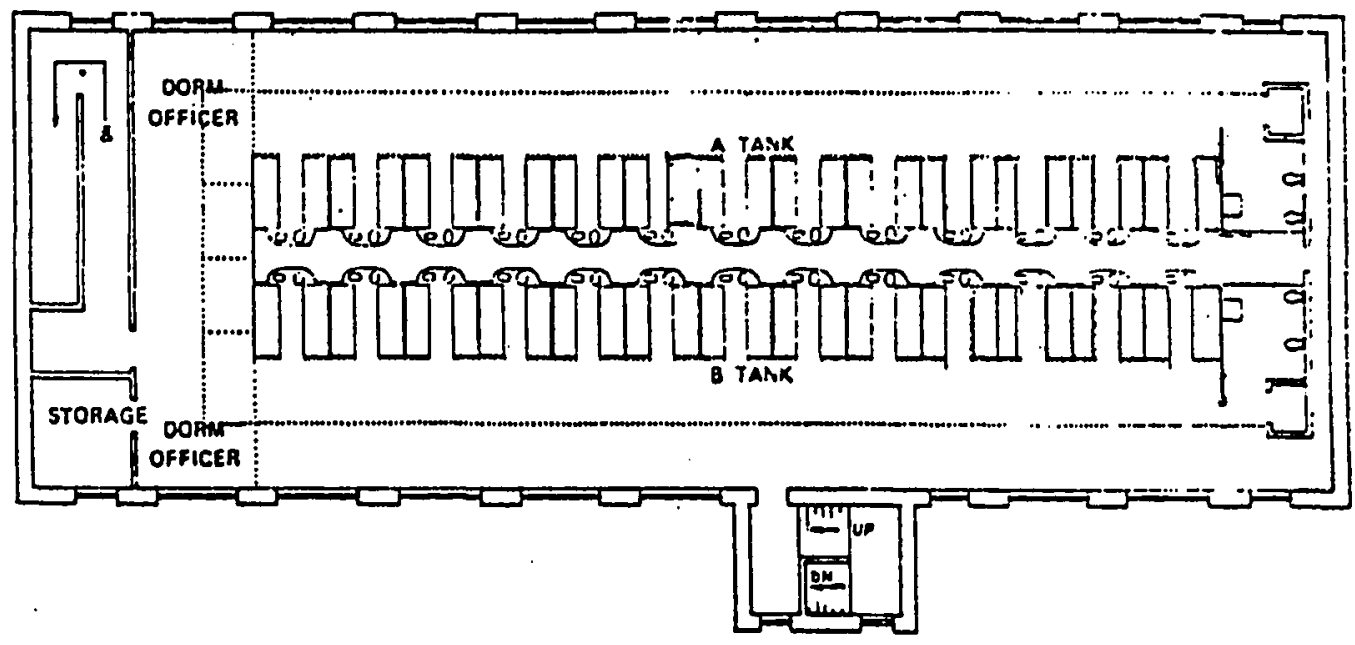


The rated capacity of A Tank was 53 persons -4 persons to a cell and one person in the single occupancy cell.

\section{B TANR}

B tank was physically identical to A tank and was also offically rated at 53 capacity. However, in 1970, the working capacity was reduced to 27 in order that seriously disturbed or disruptive inmates could be placed in separate cells so as to reduce danger to other inmates. In 1971, the working capacity was reduced to 14, allowing for only one person to a cell, justified by a need to isolate severely disruptive or dangerous prisoners.

Figure 3

C TANK

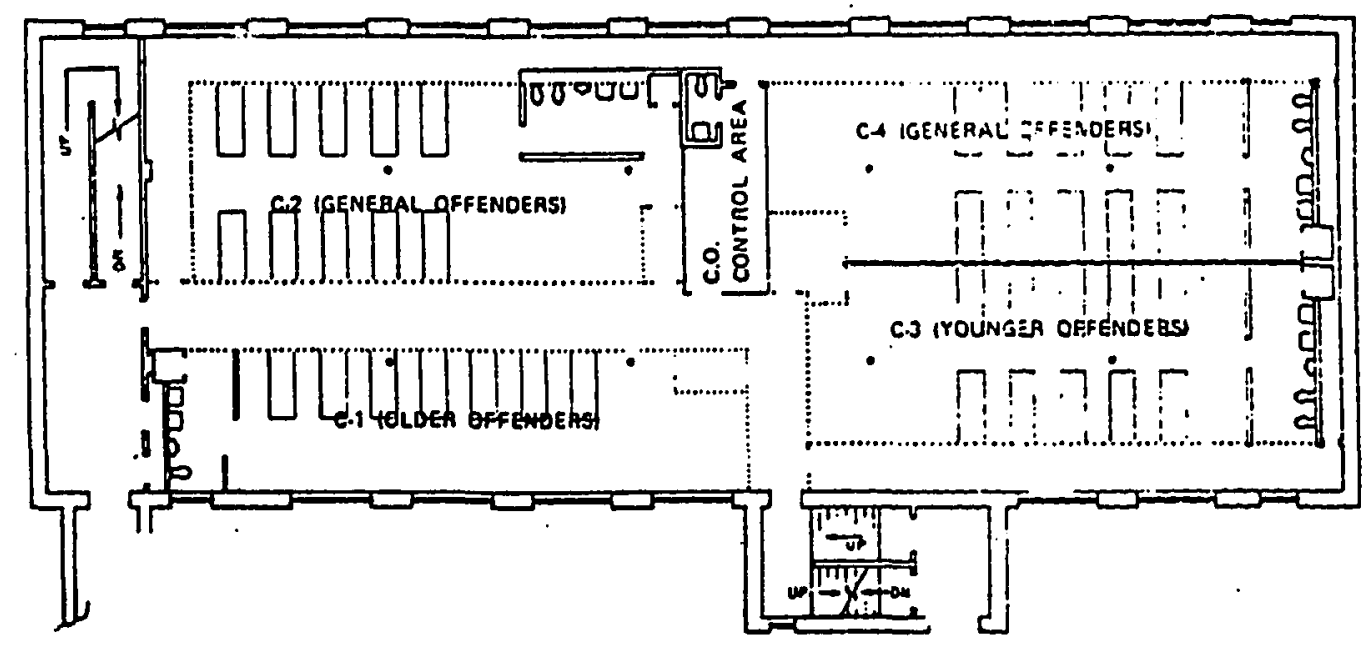

$\underline{\text { C TANK }}$

The four units designated $\mathrm{C} 1, \mathrm{C} 2, \mathrm{C} 3$, and $\mathrm{C} 4$ were located in the middle of the north building. The rated capacity for those units was 74 and they occupled approximately 3,500 square feet, not including cor- 
ridors, stairs and storage. This floor plan was somewhat unique since the officer's station was located in the middle of the floor surrounded by bars and physically isolated from the inmates. His position was that of observer, and he could not enter the tank, without adequate backup, in case of an assault or a fight. This was an open dormitory with one tank reserved for the more assaultive and dangerous persons; another tank was reserved for the weaker less aggressive individuals but who were not so weak or aggressive that they had to be isolated; and finally, the other two tanks were reserved for general population prisoners.

Figure 4

D \& G TANKS

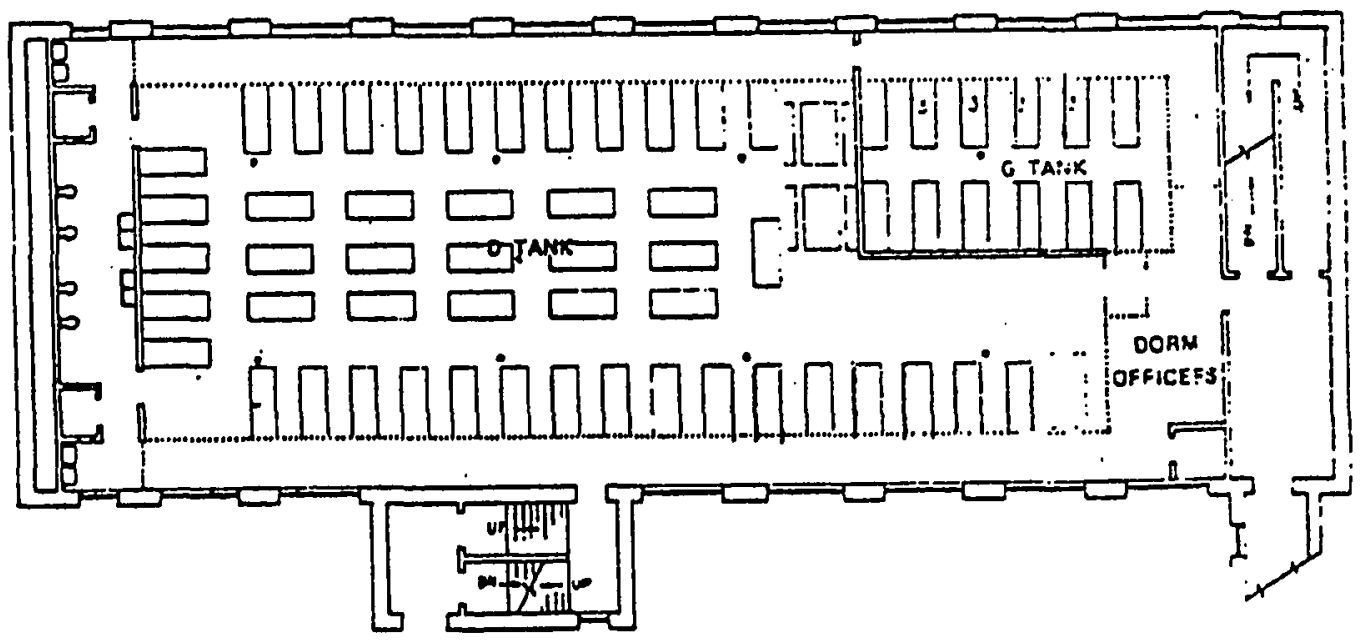

D $\underline{\text { TANK }}$

This unit was located on the middle level of the south building and was rated the largest capacity of any unit. Located in this tank were 49 double bunks, giving it a capacity of 98 . This was an extremely crowded, dark, foul smelling tank that was impossible to adequately 
supervise. A good deal of skullduggery occurred in this unit that did not come to the attention of the officer. "An animal house; wild; a kennel;" was the description given to both $D$ and $E$ tanks both by inmates interviewed in the tank and former inmates. "The worst thing about D and $E$ tank is there are so many filthy people in here. People spit on the floor, defecate and don't ever wipe themselves. It's unbelievable," stated one former inmate.

\section{Figure 5}

$E \& F$ TANRS

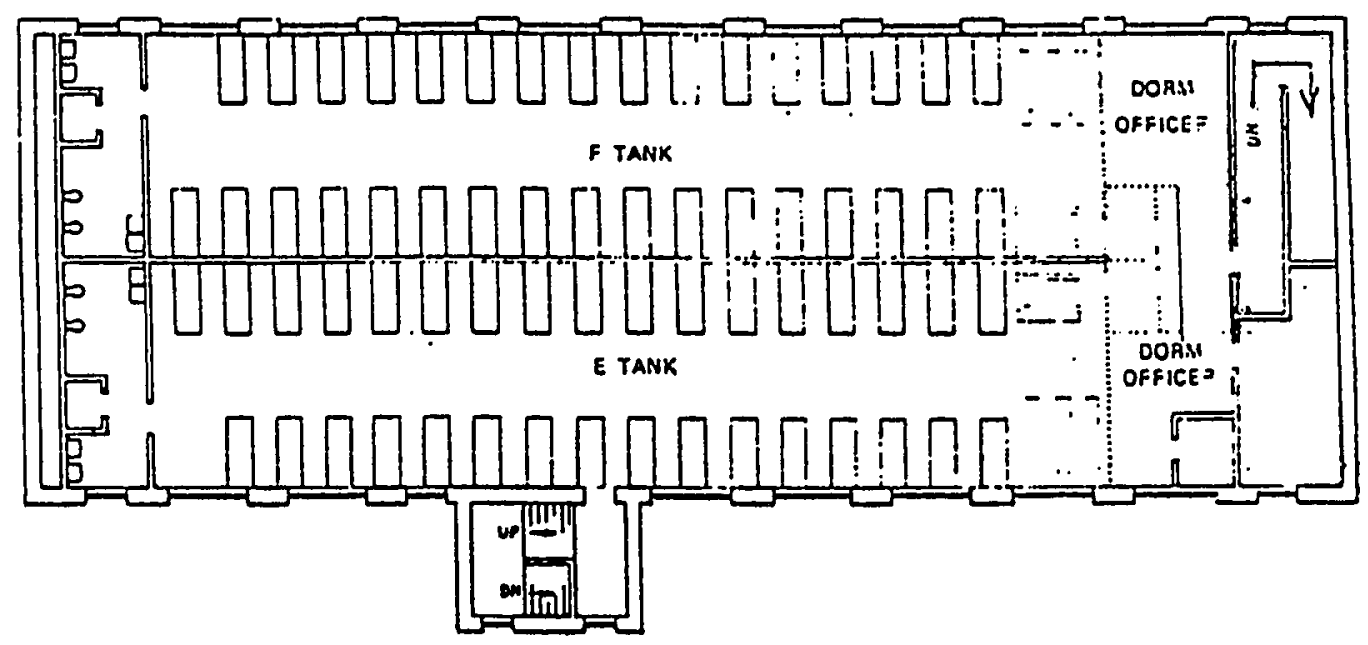

\section{G TANR}

This unit was located on the same floor of the south building as D tank, and actually was comprised of one corner of $D$ tank. It was enclosed by a masonry wall and housed the weaker and more vulnerable inmates. It too was dark and difficult to adequately supervise. E TANR

This unit shared the top level of the south bullding with the 
identical F tank. There was no peripheral officer's walkway around these tanks and each of them contained 2,236 square feet of floor space with a rated capacity of 60 . However, there were of ten many more beds than rated capacity, creating overcrowded and generally unpleasant conditions such that this unit was difficult to supervise and was relatively unsafe.

F TANK

This unit was identical to $E$ tank in dimensions and capacity and also was overcrowded, dark, and unsafe.

Figure 6

R TANK \& ISOLATION UNIT

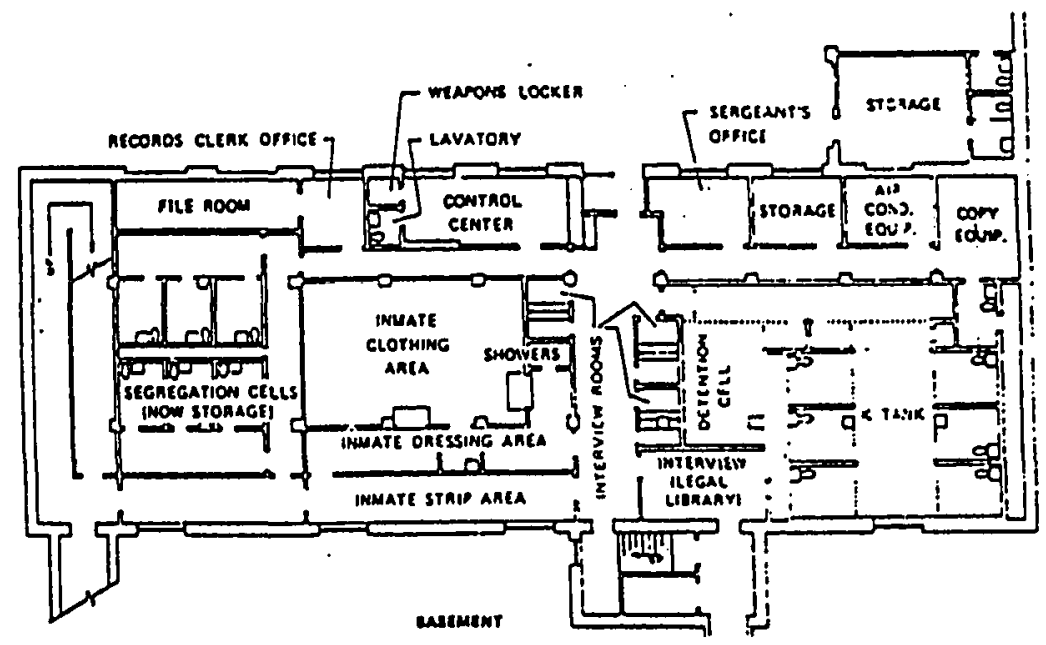


$\underline{\mathrm{K}}$ TANR

$\mathbb{K}$ tank was located in the bottom level of the north building and consisted of six two-person cells with an exercise area. It contained 720 square feet, not including the detention cell adjoining it. However, this area had not been used for some time due to poor ventilation, poor light, and inadequate facilities, as well as a court order prohibiting its use without 24 hour staffing.

$\underline{\text { UNIT }}$

This was a unit of 50 trustees and was probably the most pleasant tank in the jail. It was well lit, recently constructed (within the last three years prior to the closure of RBJ) and, of course, contained only trustees. The officer in this tank, even though separated by the bars, was usually a little more amiable and easier to deal with.

It should be kept in mind that Rocky Butte Jafl was outdated by the time it was opened in 1947 due to the basic architecture and means of construction. In addition, the population increase in Multnomah County that occurred during the 1960s, 1970s and early 1980s (in combination with the "baby boom" members coming of age) placed a strain on the total criminal justice system and caused overcrowding of a magnitude that was unanticlpated by the planners of RBJ. Two years prior to the closing of RBJ in 1983, the public hue and cry for reform of the total justice system in Multnomah County, and particularly the jail division, reached deafening proportions. In May 1981, there was an escape in which inmates had been able to smuggle a hacksaw blade into the jail, saw through bars without being detected, and seven inmates managed to escape before being detected. This eplsode was further complicated by poor 
decision-making and poor handling of the incident by the correctional staff. Then, in June of 1982 , a gun was smuggled into B tank where some exceptionally notorious and dangerous prisoners were being housed. They were able to take four civilian hostages who were working with a local prison ministry, and by use of a single key were able to gain access through the jail to the control center on the main floor. At that time, a fracas developed, resulting in an officer being shot in the back of the head as he was attempting to radio for help. These two incidents preceded the opening of the Multnomah County Detention Center by approximately eighteen to twenty-four months and also brought about the passage of a measure that had been placed on the ballot for the voters to consider in June of 1982. The result was a change in the county charter, causing a complete overhaul of the criminal justice system and the manner in which services were delivered to the voter in Multnomah County. Obviously, the final months of Rocky Butte Jail were spent under a dark cloud and its closing was greeted with a good deal of rellef, not only by the citizens of the county, but by many of the actors in the criminal justice system.

MULTNOMAH COUNTY DETENTION CENTER (MCDC)

The description of the MCDC that follows reflects the facility as it was prior to recent (post 1985) population pressures to expand the population capacity and modify the inmate housing areas without expanding the available floor space. There are jail population problems in Multnomah County that the Sheriff's Department must contend with that 
are beyond the ability of the Department to solve. For example, if at all possible, Circuit Court Judges continue to sentence felony offenders to one year in jall followed by probation rather than giving them a sentence to the Oregon Department of Corrections. Another problem that contributes to overcrowding is that the Judges refuse to establish a night or weekend court. If such a court were established, the large group of prisoners held over the weekend could be arraigned before Monday or Tuesday of each week as is now the practice. Currently, overcrowding is worse on Monday and Tuesday. By Wednesday of each week the population has declined, but on Thursday night it begins to build up again. But in spite of current policy problems, the MCDC is an outstanding example of a progressive attitude on the part of criminal justice planners.

There are many well-worn emblems of city and civic life. In some urban areas, it is necessary to reduce concepts such as justice or civic responsibility to symbols that can be grasped on a human level. The Multnomah County Detention Center is such a symbol and the architects and planners believed that it could occupy a place in the downtown area and be a significant and handsome addition to the central business district. Outwardly, the building itself implies grace and dignity while at the same time, remaining approachable and accepting.

At the time the downtown justice center was proposed to the city fathers, the Portland transit mall had been recently completed and had gained national recognition for the beauty it added to the downtown area and its ability to streamline public transportation. As a consequence, grave objections were raised relative to a "jail" on the bus mall. 
Fortunately, farsighted public officials recognized that, given participation of various government agencies as co-owners and by acknowledging the advances in modern architecture and technology, a properly-designed jail could serve the criminal justice system in the county and allay the fears of citizens that a jafl would be a blight on the bus mall.

Initially, the justice center was to be placed on the block next to the county building, with a sky bridge connecting the two in order to accommodate foot traffic to and from court rooms in the county building. A series of political moves and negotiations within the community resulted in the justice center being located directly across Chapman Park from the Portland Bullding, designed by Michael Graves. Its location adds to the beauty of the Central Business District, but it also added expense to the MCDC budget in terms of transportation of prisoners to the Court House for trial.

The bullding itself has a skelton of cast-in-place, ducktile-reinforced concrete, clad in precast concrete (similar in color and finish to the granite of older landmark bulldings nearby). The three story, foursquare base, whose polished walls are slightly darker than those of the Chamfered Tower, beckons passersby with a pedestrian arcade fronting the park, with sidewalk cafe tables, shops along mainstreet, and display windows on Madison Street. Prominent arches distinguish portals to the separate areas of corrections and law enforcement; a glazed, barre1vaulted lobby to the west leads into the courtroom and visitors' reception area. Offenders in custody enter less ceremoniously but quite efficiently through a garage door descending to a basement sallyport via a ramp off Second Avenue. 
A deep setback on the west facade lessens the apparent mass of the tower on Chapman Square (the park directly across the street from the Justice Center). More emphatically vertical when seen from the east, the Justice Center joins the rank of highrises that increasingly dominate the Portland skyline. The diagonal facets of the tower result from the roughly triangular layout of 32 cell detention modules, which are clustered three to a floor (a configuration that combines optimum sight lines for a control staff with sufficient exposure to natural light).

Figure 7

MCDC

VERTICAL PLAN

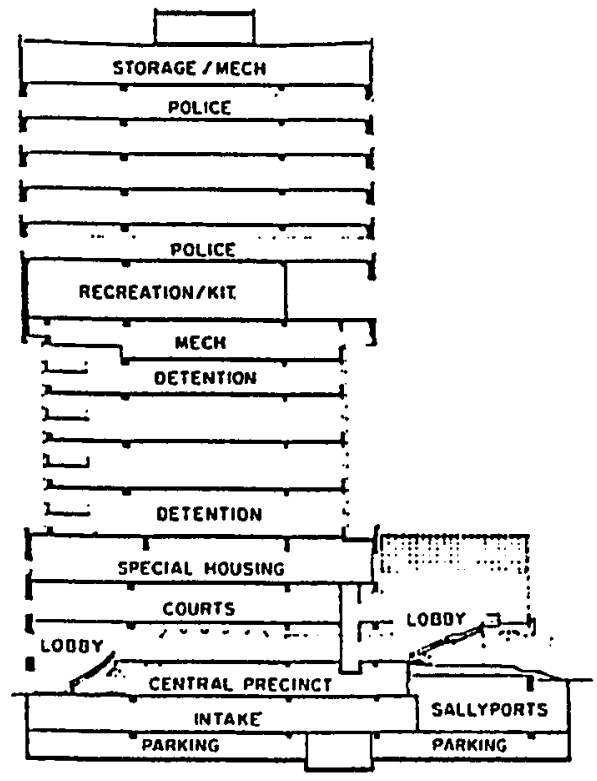

Communal rooms for jail inmates are grouped behind multistory reflected niches set into the east and west facades. Banking tiers of recessed, slit-like cell windows are fitted with horizonal ledges for 
visual privacy. The tenth floor is seen as an open band from the front of the building and is the outdoor recreation area for prisoners. Generous glazing on the five uppermost stories opens police administration offices to the beauty of city, mountains, and water, as well as a full view of the more extroverted Portland Building.

The courtrooms are relatively modest in scale as they are intended only for preliminary hearings and first arraignments. It is the building's entries and lobbies that convey the majesty of the law more overtly through the forces of architecture and art. Concrete walls--as fine as ashlar masonry, terrazo floors, coffered ceilings, marble trim, stainless steel balustrades, and copper lamps--attest to the community's dedication to 1 per cent of building costs for art. All art within the building was selected by an elght-member committee that included architect Robert Frasca and many of the art works in the Justice Center were especially commissioned as intregal parts of the building. In some instances, the various artists' styles conflict with that of the architects; for example, Harlenguen Mosaics applied to the arcade celling and a strikingly-colored lobby mural are less reserved than one expects in this type of building. There are also models of sympathetic enrichment (most notably the golden travertine pylons sculpted by Walter Duzenberry) that stand as sentinels flanking the entrance on Chapman Park and the overhead arched window by stained glass designer Ed Carpenter.

The housing floor plan allows a maximum amount of activities for prisoners with a minimum amount of movement between floors. For example, food is precooked and blast chilled in the kftchen on the tenth floor and then just prior to meals is transported to each housing unit, 
reheated, and served within the unit. This system is comparable to that used on commercial airlines and the dining space is available for other purposes during the day. On the tenth floor, which also includes the educational center, a library, indoor gymnasium, and the kitchen are outdoor recreational facilities used year round.

INTAKE BOOKING

The booking floor holds 48 prisoners on a temporary basis. Here, Figure 8

INTARE/BOORING

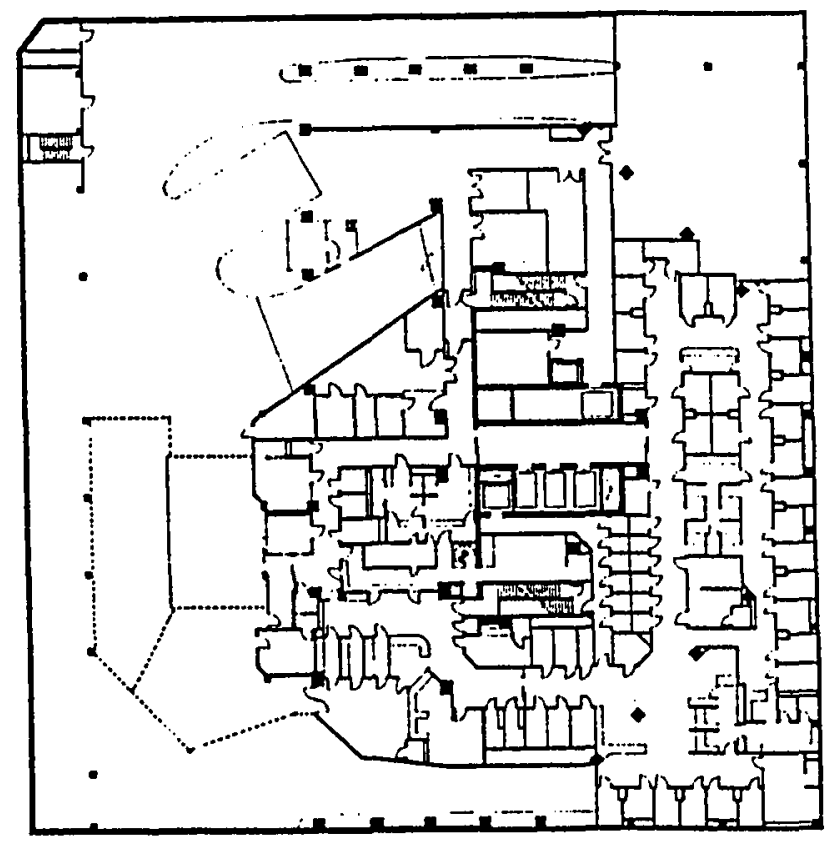


buses or police cars drive down a ramp from Second Street and park in a vehicle sallyport before discharging their passengers into a central area. The police officer then places his or her prisoner, still in handcuffs, in a specially designed holding cell that accommodates up to six people, and then fills out the paper work. His or her handcuffs are returned, via a pneumatic tube, once the prisoner is taken from the holding cell on the other side into the initial search area. The prisoner is then booked, inspected by a registered nurse, deloused if necessary, and then taken to the waiting area where he or she completes the booking process and is interviewed by a recognizance officer. The allowable time for a prisoner to be held in the booking facility is no more than 24 hours, but more usually it is 8 to 16 hours before the prisoner is moved upstairs to be placed in a holding module awaiting assignment to one of the general housing modules.

GENERAL HOUSING

General housing occuples four double height floors--five through eight. Each floor has 96 Individual cells in three, 32-person modules. Each module has two tiers of 16 cells circling a dayroom with an 18 foot celling. All cells are posttioned on outside walls and each cell contains a window, bunk, desk, toilet, and a mirror. Special strength glass substitutes for the traditional window bars on floors five through eight, and each dayroom has showers, seating, bookshelves, two televisions, and two telephones. Officer work stations are not separated from the activity area but are a part of the dayroom. The officer is required to interact on a personal basis with the prisoners. The furniture and all furnishings and colors in the unit are designed to maximize 
comfort and to enhance the spirit, rather than to depress it.

Figure 9

GENERAL HOUSING

FLOORS 5-9

N-min at.

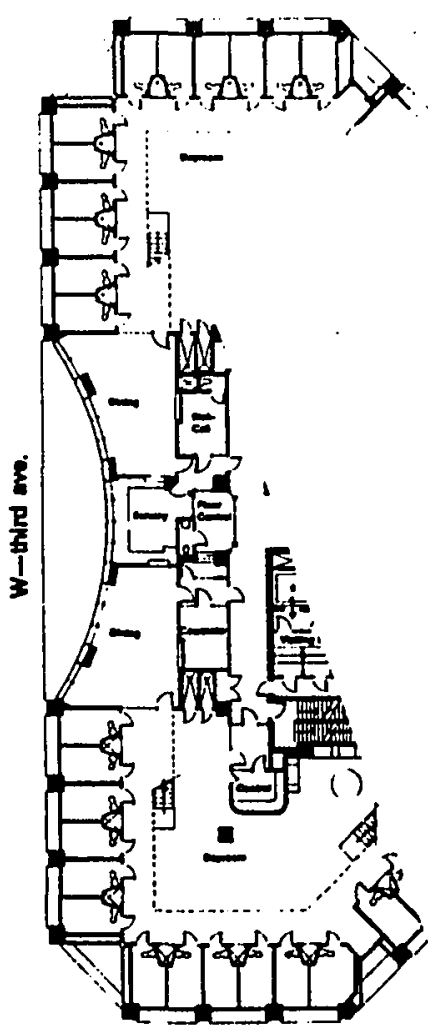

S-madicon at

SPECIAL HOUSING

The fourth floor is devoted to special housing for those persons with medical or behavioral problems. A total of 46 beds, in addition to medical services and equipment, are located on this unit. The medical facility is completely accredited by the National Commission on Correctional Health which was formerly the AMA Committee on Standards for 
Health Care Services in Jails. Prisoners are not brought to the fourth floor facility except to be placed in the medical unit. Sick call is held twice a day in all units when a registered nurse brings a specially designed cart to each module and interviews inmates to determine if there is a problem that can be dealt with in the module or if a movement to the hospital module is necessary.

The module containing prisoners judged to have behavioral problems is more secure. The officers need not interact with the inmates unless an emergency occurs. Specially designed doors and procedures enhance the safety of the unit while the architecture and furnishings are intended to accommodate the emotional and psychological needs of the prisoner.

FUNCTIONAL UNIT MANAGEMENT

The design of the MCDC easily lends itself to the utilization of Functional Unit Management (FUM) as a tool for assuring the timely and effective delfvery of services to the inmates housed in the MCDC. Functional Unit Management is a concept developed by the U.S. Bureau of Prisons $^{2}$ in the early 1970 s as a response to the Director's decision to decentralize Bureau of Prisons institutions. As defined by the Bureau of Prisons, a functional unit is a small, autonomous unit with 50-100 inmates who remain in that unit for the service of their sentence or until transfer. The unit has its own staff comprised of a unit manager, a case manager, a correctional counselor, and secretary. In addition, a teacher and psychologist would supplement the efforts of unit staff. 
The MCDC can easily be managed by the FUM concept simply by creating a semi-autonomous unit on each floor. Each unit manager would have correctional officers, counselors, and any other non-medical staff reporting directly to him or her. The Unit Manager in turn would report directly to the Jail Commander. The advantage of such a management concept is that services would be delivered more quickly, decisions would be made by staff familiar with the inmate, and the perception of inmates of an impartial, uncaring staff would be at least partially eliminated. This concept was brought forward by the Transition Team staff prior to opening the MCDC, but was rejected in favor of the traditional pyramidal form of institutional organization. As a consequence, a 1980's type of facility is managed with a 1900's style of management.

\section{SUMMARY}

Clearly, the Multnomah County Detention Center has provided an unexpected bonus to the central business district of Portland. In addition, as the architect and planners expected, the blend of architecture, technology, and behavioral science advances have combined to create a jail that is attractive, humane, and efficient. Prisoners are safe, are not subjected to the sort of indignities that were part of the old Rocky Butte JaIl and the location in the downtown area close to public transportation facilitates visits and attorney contact. 
POST RESEARCH POSTSCRIPT

Since the data for this research were obtained, the jail population has reached unexpected numbers. Some of this increase is due to policy changes that inhibit the timely release of prisoners who could be released earlier. Others who would normally be sent to the Oregon Department of Corrections are being sentenced to one year in jail with probation to follow. This practice is employed as an alternative to a commitment to the Department of Corrections, where the sentencing judges believe the felon is given parole too quickly.

The result of the increase in the inmate population has been the reopening of Claire Argo Center for Women (CAC), subsequent closing again, and reuse of the Court House Jall as a place to confine prisoners--even on a short-time basis. These developments have served to somewhat distort the goals of the MCDC and the intentions of the planners. Properly used and managed, the MCDC is a showcase for such a concept as Unit Management. But until the authorities in Multnomah County are able to control the jail population, taxpayers will not realize the full potential of the MCDC. Instead they will begin to read and hear media accounts of fail overcrowding, perhaps a rise in assaults and vandalism in the jall, and staff dissatisfaction with working conditions, all of which translate directly into an increased budget for the jail in order to deal with the effects of overcrowding. When the population is reduced, the findings of this study will be relevant and useful. 
FOOTNOTES

1 Alan J. Davis, "Sexual Assaults in the Philadelphia Prison System and Sheriff's Vans," in Clifton D. Bryant, ed. Sexual Deviancy in Social Context (New York: New Viewpoints, 1977).

2 Robert B. Levinson and Roy E. Gerard, "Functional Units: A Different Correctional Approach," Federal Probation 37, No. 4, (December, 1973): pp. 8-16.

W. Alan Smith, Ph.D. and C.E. Fenton, "Unit Management in a Penitentiary: A Practical Experience," Unpublished paper presented to the American Correctional Association Congress, Milwaukee, Wisconsin, 1977 . 
Chapter IV

THE RESEARCH APPROACH

INTRODUCTION

In the five years preceeding the opening of the Multnomah County Detention Center, the media carried almost daily accounts of the deteriorated and unsafe conditions at Rocky Butte Jail. These conditions were the topic of many discussions in County Commissioner meetings, and in addition, a class action sult was filed against the county in order to assure a lower population level and weekly exercise for the prisoners. At the time, no social policy issue was before the public more often than Rocky Butte Jail. The public hue and cry over RBJ, combined with the I-205 by-pass construction that was to pass through the side of RJB, brought about the eventual closing of Rocky Butte Jail and the opening of the MCDC. As a member of the Transistion Team that prepared for the opening of the MCDC, I recognized a unique opportunity for original research and selzed upon that opportunity.

The construction of the Multnomah County Detention Center offered a natural experiment and an opportunity to investigate what effects, if any, are observed in staff and inmate behavior and attitudes after a change in jail design is experienced. This study was a pre- and postevent research investigation that used the Rocky Butte Jail and the Multnomah County Detention Center as the setting for this inquiry. The Sonoma County (Callfornia) and Salt Lake City (Utah) jalls served as 
control jails and were selected after consultation with the technical assistance staff for the National Institute of Corrections. The control jails were deemed to match Rocky Butte Jail in terms of physical and population size, ethnic makeup of inmate population, and general "feel" in terms of tension level, noise level, and appearance. Just as important, neither jail was expected to make any major program changes or embark upon a building program during the period of the study.

The pre-event data were gathered from 498 staff and inmates in August-September 1983 at the two control jalls and at Rocky Butte Jail. After being analysed, the data were then set aside until the new MCDC was opened in November 1983. After a period of time had elapsed, a comparison of the social climate data from RBJ with social climate data from the MCDC was to be made to determine what, if any, changes had occurred. The post-event data were gathered in August and September 1984 from 377 respondents from the two control jails and the Multnomah County Detention Center. The samples appear to be reasonably representative of the total inmate population in that the investigator had free access to all jalls and was allowed complete freedom to solicit volunteers in each cellhouse and the tanks of all jails. Some sample bias might be expected, since volunteers are most apt to step forward if they are overly satisfied or dissatisfled with the jail. Any non-probability sample has inherent problems, including that of uncertainty as to the degree of representativeness of the sample population. Indicative of some sample bias, fewer volunteers presented themselves from the segregation units and more of them stepped forward from the Trustee Units but this pattern did not vary from jail to jail. The samples were 
non-probability ones, and included participating correctional officers and inmates at Rocky Butte Jail, Portland, Oregon; Sonoma County Jail, Santa Rosa, California; Salt Lake County Jail, Salt Lake City, Utah; and the Multnomah County Detention Center, Port1and, Oregon.'

The Moos Correctional Institution Environment Scale ${ }^{2}$ (CIES) was administered to staff and inmates who volunteered in all three institutions in August and September 1983 and again in August and September 1984. The CIES (Form R) contains nine subscales which are organized around three principle dimensions relevant to correctional institutions: (1) people-to-people relationships, (2) institutional programs, and (3) institutional function. The nine subscales are described as follows in the CIES Manual: ${ }^{3}$

Relationship Dimension

1. INVOLVEMENT: Measures how active and energetic
inmates are in the day-to-day
functioning of the program, (i.e.,
interacting socially with other
residents, doing things on their own
initiative, and developing pride and
group spirit in the program.)
Sample Statement: Residents on the
unit care about each other.

2. SUPPORT:

Measures the extent to which residents are encouraged to be helpful and supportive towards other inmates and how supportive staff is toward residents.

Sample Statement: Staff help new residents get acquainted on the unit.

3. EXPRESSIVENESS:

Measures the extent to which the program encourages the open expression of feelings (including anger) by residents and staff. Sample Statement: On this unit staff think it is healthy to argue. 
Personal Development

4. AUTONOMY:

5. PRACTICAL ORIENTATION :

6. PERSONAL PROBLEM ORIENTATION:

\section{System Maintenance}

7. ORDER AND ORGANIZATION:

8. CLARITY:

9. STAFF CONTROL:

\begin{abstract}
Assesses the extent to which inmates are encouraged to take initiative in planning activities and take leadership in the unit.

Sample Statement: The staff act on resident's suggestions.
\end{abstract}

Assesses the extent to which the residents environment orients him toward preparing himself for release from the program: training for new kinds of jobs, looking to the future, and setting and working toward goals are considered.

Sample Statement: Residents here are expected to work toward their goals.

Measures the extent to which residents are encouraged to be concerned with their personal problems and feelings and to seek to understand them.

Sample Statement: Residents are expected to share their personal problems with each other.

Measures how important order and organization are in the program, in terms of residents (how they look), staff (what they do to encourage order), and the facility itself (how well it is kept).

Sample Statement: The staff make sure the unit is always neat.

Measures the extent to which the resident knows what to expect in the day-to-day routine of his program and how explicit the program rules and procedures are.

Sample Statement: If a resident breaks a rule, he knows what will happen to him.

Assesses the extent to which the staff use regulations to keep residents under necessary controls, (1.e., in the formulation of rules, the scheduling of activities, and in the re- 
lationships between residents and staff.)

Sample Statement: All decisions about the unit are made by the staff and not by the residents.

The first three subscales of involvement, support, and expressiveness are conceptualized as measuring a relationship dimension. They assess the extent to which inmates tend to become involved in the unit, the extent to which the staff supports inmates and inmates support and help each other, and the extent of spontaneity and free and open expression within all these relationships. These subscales essentially emphasize the type and intensity of personal relationships among residents and between residents and staff.

The next three subscales--autonomy, practical orientation, and personal problem orientation, are conceptualized as making up a personal development or treatment program dimension. The subscales are particularly relevant to the type of treatment orientation the unit inftiates and develops. Autonomy gauges the extent to which inmates are encouraged to be self-sufficient and independent and to take responsibility for their own decisions. This is clearly an important treatment program variable and reflects a major value orlentation of program staff. The subscales of practical orientation and personal problem orientation reflect two of the major types of treatment orlentations which are currently in use in correctional institutions. For example, some. institutions or units place extremely high emphasis on practical preparation for the inmate's release from the institution, such as training for new kinds of jobs. On the other hand, some institutions or units strongly emphasize a personal problem orientation and seek to 
orient inmates toward increased self-understanding and insight. It is, of course, possible for some correctional institutions or units to emphasize both of these dimensions, just as some may emphasize neither. In addition, since the primary mission of a jail is commonly defined as one of security, the presence of high scores on these dimensions would be relatively rare.

The last three subscales of order and organization, clarity, and staff control are conceptualized as assessing a system maintenance dimension. These component scales are system oriented in that they tap the extent to which the correctional unit or institution functions in an orderly, clear, organized and coherent manner.

Each of the 90 items is expressed as a statement to be marked "true" or "false" by the inmates or by the staff members. For example, one 1 tem stated that "Staff go out of their way to help residents." The only response categories provided were true or false. If staff are percelved as helpful then the expected response is true, but if staff are seen as aloof, unhelpful or unavallable, the expected response is false. Items are worded so that the respondent, by marking "true", indicates that he or she feels that the expressed behavior or condition is present or encouraged in his or her institution or unit. A "false" response indicates that he or she feels it is not present or encouraged. In other examples, question \#1 states that "the residents are proud of their unit," question \$34 proclaims that "This is a very well organized unit," and question \#66 asserts that "It is hard to tell how residents are feeling on this unit."

A score is obtained for each subscale by adding up the number of 
items on the subscale which have been answered in a specified direction. Average scores (residents and staff) are then calculated for each subscale and unit (jail), while profiles are generated that compare scores among the jails. On the CIES scale, the jail profiles are then compared to the national norm.

Beginning in 1969 attempts were begun to standardize the $\dot{C} I E S$ through a grant from the National Institute of Mental Helath to the National Council on Crime and Deliquency. The CIES was administered to persons in adult correctional programs in institutions in Arkansas, California, Connecticut, Hawali, Illinois, Rentucky, Mississippi, New Mexico, New York, Vermont, Washington and In some institutions of the Federal Bureau of Prisons. After the data were in, the inmate and staff samples were rescored, resulting in the factoring of some scales, e.g., Affliation and Involvement were combined into a subscale, Involvement, and a national profile was developed. In the improved CIES, nine subscales replaced the original fourteen and a score of 50 was found to be the national norm. Thus, a group or institution receiving a score greater than 50 is determined to be moving in a positive direction, while a score less than 50 is regarded as showing movement in a negative direction.

In scoring Individual questionnaires, it is not a matter of adding up the number of right and wrong answers, but of converting the raw score to a standard score. ${ }^{4}$ For example, on the subscale of Involvement, if the inmate respondent had a raw score of 5 , his standard score would be 54 indicating that his perception of involvement in his unit would be slightly better than the national average. If ten raw scores 
are summed to arrive at a total of 250 , then the mean score would be 25 indicating that collectively the ten respondents in that unit perceived low involvement among the inmates on that unit. The score of 25 is then compared to the national norm of 50 and we then determine that the level of involvement in this unit is perceived to be only half the level that is perceived in correctional programs nationally. The subscale of Staff Control may be an exception in regard to a score over 50 being more positive. A jail's central mission is control of the prisoner population, and a high score on the subscale of staff control should not necessarily be interpreted as undesirable.

Finally, the data are nominal; that is, response categories are either true or false. In addition to responses on the 90 statements, respondents were asked to provide the following information: (1) age, (2) sex, (3) How long have you been confined or worked in this jatl? coded as ( $\mathrm{T} 1$ ), and (4) In your lifetime, how long have you spent or worked in correctional institutions? coded as (T2). These questions were asked in order to be used as covariats in the analysis of the data.

Regarding subscale internal consistencies and intercorrelations, on a sample of 22 correctional programs using average within-program variances, Moos $^{5}$ calculated that the internal consistencies were all in an acceptable range and varied from moderate to substantial. He ${ }^{6}$ also found through analysis of variance that CIES subscale patterns among correctional programs were almost always significant for both residents and staff, especially when sampled from different correctional institutions. He used the Estimated Omega Squared to calculate the average properties of the total variance accounted for by differences among 
programs, which varied from a low of $5 \%$ to a high of $40 \%$. On the average, differences among programs accounted for about $25 \%$ of the varlance of residents' responses and $20 \%$ of the variance for staff responses.

When the relationships between subscales and individual characteristics were examined, Moos $^{7}$ found that the nine subscales were relative1y independent of individual background characteristics on resident and staff responses to the CIES (all correlations were less than .10).

As indicated above, there are nine subscales which are all scored in a specific, positive direction. Those scores are averaged and unit profiles for both males and females, staff and inmates, are calculated in the following manner. The number of items to be responded to are noted below:

$\begin{array}{lr}\text { Involvement } & 9 \\ \text { Support } & 10 \\ \text { Expressiveness } & 10 \\ \text { Autonomy } & 9 \\ \text { Practical Orientation } & 10 \\ \text { Personal Problem Orientation } & 9 \\ \text { Order \& Organization } & 9 \\ \text { Clarity } & 10 \\ \text { Staff Control } & 10\end{array}$

There have been some criticisms of Moos's Correctional Institutions Environment Scale. ${ }^{8}$ Wright and Boudouris have claimed that it is unclear as to what the scores on the nine subscales indicate and that it is difficult to determine what is being measured by the CIES. They agreed with Selo ${ }^{9}$ in her review of Moos's Evaluating Correctional and Community Settings, in which she stated:

I had considerable difficulty in disentangling several of these dimensions and this was not made easier by examining the individual items. Since we are not given correlations between all the 1 tems or with correlations between subscale 
scores it is difficult to deterpine the extent to which the dimensions are really separate.

Selo was not completely negative in her evaluation of the CIES and contended that comparisons of particular programs over time, the impact of treatment interventions, and comparisons of different units within a program could all be facilitated by the CIES. But, like Wright and Bourdouris, she belleved that there are conceptual and methodological problems with the Scale.

Wright and Boudouris concluded that two questions need to be answered in assessing the utility of the CIES. First, do the particular attributes of correctional climate actually exist and do they have some impact upon behavior within the penal setting? Second, are the dimension's accurately measured by the instrument? In their research, they administered the CIES questionnaire to a group of inmates and staff in Iowa's seven correctional institutions in May 1979. They used the Statistical Analysis System (SAS) and looked at intercorrelations among single items as well as performing factor analysis and cluster analysis on the data.

In contrast to Moo's claim that all intercorrelations were within acceptable ranges, Wright and Boudouris observed higher intercorrelations, often exceeding .60 , among items from presumably different scales. Moos claimed that few intercorrelations among items from putatively different scales exceeded .50 and most of ten did not exceed .40. In their factor analysis, Wright and Boudouris reported that the majorlty of the questionnalre items were associated with only three factors. Finally, after a cluster analysis of the data, they reported 
that the factors did not group as Moos claimed and the clusters were not as tight as Moos claimed.

Overall, Wright and Bourdouris admitted that their findings were not conclusive and only pointed the way for further research. They also found fault with Moos's theoretical orientation, but did not cite Tagiuril and confessed ignorance about the concept of organizational social climate. Previous authors have made a sound case for a concept called organizational climate, even though it is an emerging one.

Wright and Bourdouris are doubtless correct in asserting that the CIES scale is not a perfect instrument. However, it is still the only research device that takes a global look at social climate. While a more perfect one would be desirable, due to the constraints of time it made more sense to use the Moos scale that has been used in other studies than to attempt to invent a new research instrument.

\section{STATISTICAL ANALYSIS}

The statistical analysis of the data from inmates and staff in the jails was performed using the Indlana State University Control Data Corporation Computer. The Statistical Package for the Social Sciences (SPSS) program was used for all the data analysis. In the chapter to follow, frequency distributions for all scaled variables are reported, along with totals and means for both inmates and staff.

The F ratio provides the degree of significance and allows us to compare the degree of significance to the line of regression drawn from the old style jafl scores and the new style jafl scores-which are derived from means computed after Analysis of Covariance. Each subscale score is graphed for each jail in order to more clearly present any 
change in the subscale scores.

The working hypotheses for the study were:

$$
\begin{aligned}
& \mathrm{H}_{1}: \text { The combined perceptions by inmates of social } \\
& \text { climate will be higher or more positive in the new } \\
& \text { jail (MCDC) than in the old one (RBJ), while } \\
& \text { little or no change in perceptions will be } \\
& \text { observed for in two control jails. } \\
& \mathrm{H}_{2}: \text { The combined perceptions by staff of social } \\
& \text { climate will be higher or more positive in the new } \\
& \text { jail (MCDC) than in the old one (RBJ), while } \\
& \text { little or no change in perceptions will be ob- } \\
& \text { served for in two control jails. }
\end{aligned}
$$

Operationally, the two working hypotheses were stated as:

$$
\begin{aligned}
& \text { Social climate score changes in a positive } \\
& \text { direction as measured by the CIES will be noted in } \\
& \text { the MCDC when compared to RBJ, while in the con- } \\
& \text { trol jails, significant changes in social climate } \\
& \text { will not be found. }
\end{aligned}
$$

One of the major difficulties of sociological research is the inability to set up experimental groups at will. However, in this case, a quasi-experimental opportunity presented itself, involving non-probabity samples of staff and inmates in several jails. Through the analysis of covariance, Jail differences can be controlled statistical1y.

The researcher anticipated that a significant difference in postevent scores would follow from the change in architecture, that is, alterations in the physical structure of the jail would produce changes in social climate, On the other hand, parallel changes were not expected in the two "control" jails. Analysis of covariance is a means for determining whether or not the differences are attributable to the architecture or covariates, which in this case are: age, sex, status 
(staff or inmate), time in the jail at present and time in jail and prison for all of the respondent's life.

The following model was used for the analysis of covariance

$$
\begin{gathered}
Y_{i j}=u+T_{i} B_{1}\left(X_{1 i j}-\bar{X}_{1}\right)+B_{2}\left(X_{2 i j}-\bar{X}_{2}\right)+B_{3}\left(X_{3 i j}-\bar{X}_{3}\right)+ \\
B_{4}\left(X_{4 i j}-\bar{X}_{4}\right)+B_{5}\left(X_{5 i j}-\bar{X}_{5}\right)+E_{i j}
\end{gathered}
$$

where:

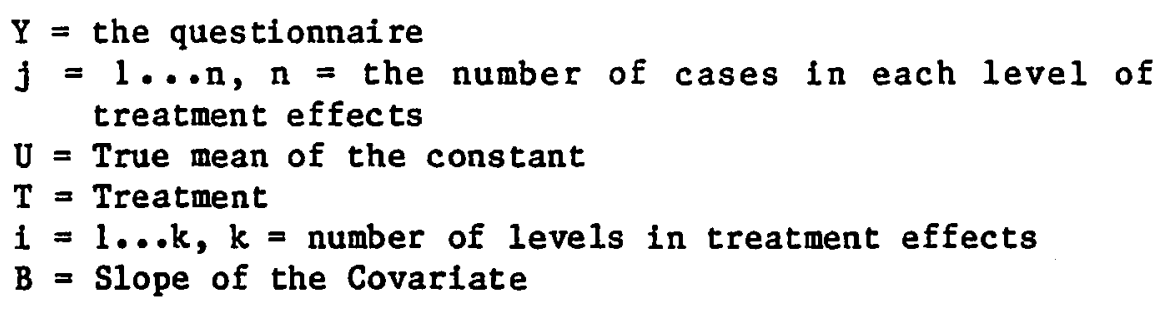

Earlier, it was indicated that one of the primary purposes of covariance analysis is to increase the precision of an experiment by removing possible sources of variance in the criterion variable (jails) that are attributable to factors not being considered in the research. If these influences can be removed statistically, the precision of the experiment is increased by reducing the error variance. The gain in precision from the use of the covariance adjustment depends upon the degree of correlation between the covariate and the dependent variable. The higher the correlation, the larger the variation attributable to the covarlate, and the more effective the analysis of covariance procedure will be in reducing the error variance. 12

As noted earlier, occastons arise in which it is not practical to use experimental groups and analysis of covariance can be used af ter the fact to remove bias due to the groups not being matched. Analysis of covariance, which is a combination of regression and analysis of variance can be used as either an extension of regression or analysis of 
variance.

In the present study where three jails are the experimental variable and where only architecture changed in one jail, we attempt to control for the influence of the covariates. To understand our regression model, imagine, if you will, a can being tossed into the air. Rifles shooting bullets (covariates) are aimed at the can from all directions and they all hit their mark. Each impact of the bullet alters the configuration of the can to such an extent that it falls to the ground altered in shape by its being hit by the bullets. This is the effect of covariates upon the experimental variable which multiple linear regression endeavors to guage. However, there are still residuals from the regression line which are subjected to an Analysis of Variance expressed in terms of an F-ratio. Thus in Table I we see the result of the ANCOVA. For example, the covariate of Status is depicted with a Sum of Squares of 1972.944 with one degree of freedom and with an F-ratio of 5.752 significant at the .017 level. The results of the ANCOVA for the Main Effects of Jail and Year appear after the covariates (see following two pages).

This analysis is made even clearer in Figure 10. In this instance, the main effect year, is plotted on the horizontal plane and the mean scores for all responses to the Involvement subscale after Analysis of Covariance are plotted on the vertical plane. We learn later from Table VIII that this positive change in perception is significant to the .003 level. Thus, for RBJ we can conclude from the combined scores on the Involvement subscale that staff and inmate mean scores improved after moving into the MCDC. 


\section{TABLE I \\ ANCOVA \\ INVOLVEMENT}

\begin{tabular}{|c|c|c|c|c|c|}
\hline $\begin{array}{c}\text { I } \\
\text { BY JAIL } \\
\text { YR } \\
\text { WITH STAT } \\
\text { AGE } \\
\text { SEX } \\
\text { T1 } \\
\text { T2 }\end{array}$ & 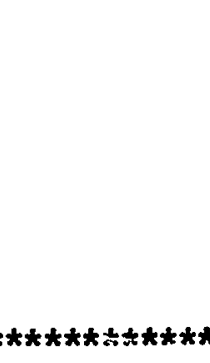 & $k \star \star \star \star *$ & 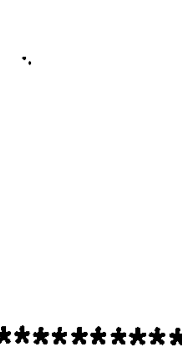 & $\star \star \star \star \star \star \star \star \star x$ & 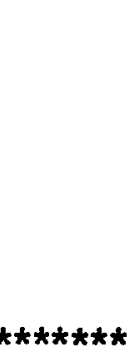 \\
\hline SOURCE OF VARIATION & $\begin{array}{l}\text { SUM OF } \\
\text { SQUARES }\end{array}$ & DF & $\begin{array}{r}\text { MEAN } \\
\text { SQUARE }\end{array}$ & F & $\begin{array}{l}\text { SIGNIF } \\
\text { OF F }\end{array}$ \\
\hline $\begin{array}{l}\text { COVARIATES } \\
\text { STAT } \\
\text { AGE } \\
\text { SEX } \\
\text { T1 } \\
\text { T2 }\end{array}$ & $\begin{array}{r}4381.935 \\
1972.944 \\
109.764 \\
65.598 \\
109.062 \\
244.277\end{array}$ & $\begin{array}{l}5 \\
1 \\
1 \\
1 \\
1 \\
1\end{array}$ & $\begin{array}{r}876.387 \\
1972.944 \\
109.764 \\
65.598 \\
109.062 \\
244.277\end{array}$ & $\begin{array}{r}2.555 \\
5.752 \\
.320 \\
.191 \\
.318 \\
.712\end{array}$ & $\begin{array}{l}.027 \\
.017 \\
.572 \\
.662 \\
.573 \\
.399\end{array}$ \\
\hline $\begin{array}{l}\text { MAIN EFFECTS } \\
\text { JAIL } \\
\text { YR }\end{array}$ & $\begin{array}{l}7121.391 \\
4612.329 \\
3127.897\end{array}$ & $\begin{array}{l}3 \\
2 \\
1\end{array}$ & $\begin{array}{l}2373.797 \\
2306.165 \\
3127.897\end{array}$ & $\begin{array}{l}6.920 \\
6.723 \\
9.119\end{array}$ & $\begin{array}{l}.001 \\
.001 \\
.003\end{array}$ \\
\hline $\begin{array}{l}\text { 2-WAY INTERACTIONS } \\
\text { JAIL YR }\end{array}$ & $\begin{array}{l}860.824 \\
860.824\end{array}$ & $\begin{array}{l}2 \\
2\end{array}$ & $\begin{array}{l}430.412 \\
430.412\end{array}$ & $\begin{array}{l}1.255 \\
1.255\end{array}$ & $\begin{array}{l}.286 \\
.286\end{array}$ \\
\hline EXPLAINED & 15962.112 & 10 & 1596.211 & 4.653 & .001 \\
\hline RESIDUAL & 203068.933 & 592 & 343.022 & & \\
\hline TOTAL & 217031.045 & 602 & 363.837 & & \\
\hline
\end{tabular}


FIGURE 10

$$
\begin{aligned}
& \text { Mean Standard } \\
& \text { Scores }
\end{aligned}
$$

60

55

50

45

40

35

30

25

20

15

5

5

\section{ANALYSIS OF CONARIANCE
STAFF AND INMATES}
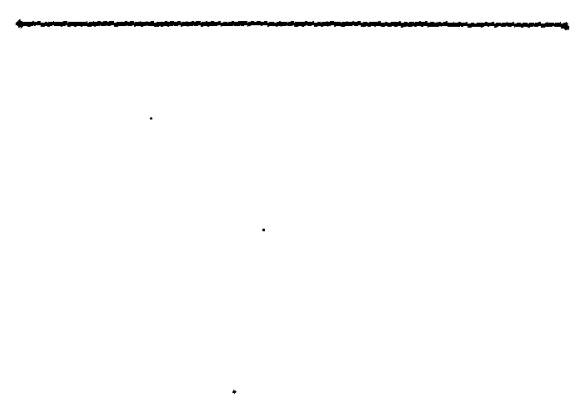

30

25

20

15

1983

40

35

60

55

so

45

1984 
As indicated earlier, the F-ratio enables one to establish a significance level and further enhances the conclusions about social climate in the respective jails. For this study a significance level of .005 or better was utilized.

The numbers, sex, and status of the respondents are provided in the following table:

TABLE II

STUDY SAMPLE

$\underline{1983}$

1984

IMMATE

STAFF

IMMATE

STAFF

Male/Female

Male/Female

Male/Female Male/Female

\begin{tabular}{|c|c|c|c|c|c|c|c|c|}
\hline $\begin{array}{l}\text { Rocky } \\
\text { Butte Jail }\end{array}$ & 128 & 28 & 33 & 13 & - & - & - & -- \\
\hline$M C D C$ & - & -- & -- & - & 112 & 22 & 22 & 4 \\
\hline $\begin{array}{l}\text { Sonoma } \\
\text { County Jail }\end{array}$ & 68 & 20 & 25 & 8 & 74 & 11 & 11 & 6 \\
\hline \multirow{2}{*}{$\begin{array}{l}\text { Salt Lake } \\
\text { County JaAl }\end{array}$} & 139 & 13 & 13 & 12 & 78 & 22 & 12 & 3 \\
\hline & -- & -- & - & $-\infty$ & $-\infty$ & -- & -- & - \\
\hline \multirow[t]{2}{*}{ TOTALS } & 335 & 61 & 71 & 33 & 264 & 55 & 45 & 13 \\
\hline & & & & & & TOTA & 877 & \\
\hline
\end{tabular}


SUMMARY

This chapter reviewed the Correctional Institutions Environment Scale and discussed its use in this study. Criticisms of the CIES were noted, along with the methodology and literature supporting use of the CIES. The data analysis approach for this study was also reviewed, along with an explanation and justification of use of analysis of covariance. Four samples totalling 877 subjects were administered the CIES in Rocky Butte Jail, Sonoma County Jail, Salt Lake County Jail and the Multnomah County Detention Center in 1983 and 1984.

In the chapter to follow an analysis of the data is presented and the findings are discussed. Finally, conclusions are drawn from the findings of the study. 
FOOTNOTES

${ }^{1}$ Jordan et al., v. Multnomah County et al., Civ. 80-841 RE (U.S. District Court. Portland, Oregon 1982).

2 Rudolf H. Moos. Correctional Institution Environment Scale, Manual (Palo Alto: Consulting Psychologists Press, Inc., 1974). p. 3 .

${ }^{3}$ Rudolf H. Moos, Correctional Institution Environment Scale, Manual

${ }^{4}$ Rudolf H. Moos, Correctional Institution Environment Scale, Manual p. 26 . p. 7 .

5 Rudolf Moos, Correctional Institution Environment Scale, Manual

${ }^{6}$ Rudolf Moos, Correctional Institution Environment Scale, Manual p. 8 .

${ }^{7}$ Rudolf Moos, Correctional Institution Environment Scale, Manual p. 8 .

${ }^{8}$ Kevin N. Wright and James Boudouris, "An Assessment of the Moos Correctional Institution Environment Scale," Journal of Research in Crime and Delinquency 19, No. 2 (July, 1982): pp. 255-276.

${ }^{9}$ Elaine Selo, Review of Evaluating Correctional and Community Settings by Rudolph H. Moos, Journal of Criminal Justice 4, No. 4 (December, 1976): pp. 348-350.

${ }^{10}$ Elaine Selo, Review of Evaluating Correctional and Community Settings, by Rudolph H. Moos, p. $3 \overline{49}$. Concept.

11 Renato Taguiri, Organizational Climate: Explorations of a New

12 Albert R. Wildt and 0111 T. Ahtola. Analysis of Covariance (Beverly Hills: Sage Publications, Inc., 1978). 
Chapter $\nabla$

DATA ANALYSIS AND FINDINGS

In this study, the perception of jail inmates and correctional officers regarding the social climate of jails was investigated. These perceptions were assessed by administering the Correctional Institution Environment Scale (CIES) to 877 consenting inmates and staff present on the day the rater visited the three fails. The CIES was first administered to staff and inmates in August, 1983 at Rocky Butte Jail, Sonoma County Jail (California) and Salt Lake County Jail (Utah). It was again administered to staff and inmates in July-August 1984 at the Multnomah County Detention Center, Sonoma County Jail and Salt Lake County Jail. The Rocky Butte Jail, Sonoma County Jail, and Salt Lake County Jail are all similar in architecture, size, age, and population make-up, except that Sonoma County Jail has more inmates with Spanish surnames than the other two jails. The Multnomah County Detention Center is quite unlike the other jails and was bullt to replace Rocky Butte jail. In this research, RBJ and MCDC were treated as one jall, but one in which the architecture and site changed during the study period.

In the two study periods there were a few inmates who participated in both administrations of the questionnaire but their impact on the conclusions based upon the analysis of the data is probably negligible. Staff, however, is another matter. Several employees participated in both 1983 and 1984 samples. Due to the procedures used to gather the 
data, that is entering the jail and asking all inmates and staff to answer the questionnaire, some staff respondents filled out CIES questionnalres twice. One point to keep in mind is that if the 1984 staff sample had been restricted to only those who had not previously participated, the 1984 sample size would have been so small as to render the results meaningless. In addition, the only area in the data analysis that is tainted by the inference of inaccuracy is the age distribution of staff. However, the 1984 age distribution helps us paint a mental picture of who participated in the 1984 staff sample.

In all three jails, 104 staff members, including 71 males and 33 females, elected to respond to the questionnal re in 1983. In 1984, 58 staff members, 45 male and 13 female correctional officers, some of whom were in the 1983 group, elected to respond to the questionnaire.

JAIL STAFF

Rocky Butte Jail was staffed by 64 corrections of ficers, of whom 46 responded to the study in 1983 . In 1984,28 officers responded from the $M C D C$, including some who responded in 1983. Any statements in regard to age and experience must be considered with that fact in mind.

The data indicated that most RBJ/MCDC officers were in the 31-44 age group, thus they were probably a more mature group of employees than at the two control jails. In contrast, Sonoma County had a younger complement of correctional officers, with the age category 22-25 most heavily represented and with the $26-30$ age group following close behind. In Salt Lake County, on the other hand, the age group 26-30 had the most respondents among the staff, with $35.5 \%$ falling in this age group. 
All jails also had relatively inexperienced employee groups. In RBJ, 39 out of 78 staff respondents had been employed in correctional institutions 2.7 years or less and 48 out of them had been employed five years or less. Overall, 84 or $52 \%$ out of the 159 correctional officers that participated in this study had less than five years of correctional experience.

The Sonoma County Jail staff participants were a younger staff group than at Rocky Butte Jail and Multnomah County Detention Center. Not surprisingly, there were fewer experienced correctional officers in the former. In terms of overall corrections experience, 17 officers claimed 2.5 years or less of employment in corrections, 16 claimed 2.5 years to 5 years experfence and 10 out of 50 reported more than 5 years experience in corrections work.

In the Salt Lake County Jail, 31 staff members, some of whom may have participated twice, responded to the questionnaire in 1983 and 1984. Of these persons, 17 claimed to have worked in the jail for 1.9 years or less while 7 reported that they had worked there between 2.7 years and 5 years. Only 4 officers said that they had worked in the jail longer than 5 years. The figures indicating previous corrections experience were nearly the same as those reported in the Salt Lake County Jail. Clearly, Salt Lake County as well as Sonoma County had a young, relatively inexperienced work force. 


\section{JAIL INMATES}

ROCKY BUTTE JAIL/MCDC INMATES

During the period that the questionnaire was administered to the inmates and staff at Rocky Butte Jail, the population was 360 inmates, which was the ceiling mandated by the court. There were 470 inmates at the MCDC during the study period in 1984. In all, 283 inmates, including 47 women, at $R B J / M C D C$ participated in the study. The number of respondents who filled out questionnalres in both study periods was negligible. In terms of age, $62.1 \%$ were between 18 and 30 years of age. A large share of the inmates, 202 in all, claimed to have been in the jail less than six months and 39 prisoners stated they had been in jall 30 days or less. Eighteen inmates reported that they had been in RBJ/MCDC between six months and one year, and three claimed more than one year in the fail.

When asked how much of their lifetime had been spent in prison or jail, a surprising 79 out of 226 inmates reported serving 6 months or less. This is surprising in that for cities of 250,000 or more population, in which category Portland falls, the arrest rate per 100,000 inhabitants in 1985 was $7,525.8^{1}$. We may also conclude from Irwin ${ }^{2}$ that a good portion of the arrestee population is comprised of rabble who repeatedly come into conflict with the law due to their "offensiveness." Thus, one would assume that inmates in RBJ/MCDC would show a larger number of persons who had served more time, probably in small increments. However, 62 inmates claimed to have served between 6 months and 2.8 years, 60 more stated they had served between 2.8 years 
and 8.9 years, and 23 reported more than 10 years of prior incarceration.

TABLE III

$\mathrm{RBJ} / \mathrm{MCDC}$

INMATE AGE DISTRIBUTION

$\begin{array}{lr}18-21 & 58 \\ 22-25 & 59 \\ 26-30 & 59 \\ 31-35 & 34 \\ 36-44 & 29 \\ 45-55 & 5 \\ 56 \text { \& older } & 2 \\ \text { Missing } & 37\end{array}$

SONOMA COUNTY JAIL

In the Somona County Jail, 173 inmates, including 31 women, particlpated in the study. The Sonoma County Jail contained fewer inmates in the 18-30 age range (53.2\%) than did RBJ/MCDC (62.1\%).

Concerning their current incarcerations, twenty-four inmates indicated that they had been locked up less than 30 days. An additional 116 reported that they had been held in custody for 186 days and eighteen others stated that they had been held between 217 days and 1.7 years.

TABLE IV

SONOMA COUNTY JAIL INMATE AGE DISTRIBUTION

$\begin{array}{ll}18-21 & 22 \\ 22-25 & 34 \\ 26-30 & 36 \\ 31-35 & 24 \\ 36-44 & 24 \\ 45-55 & 26 \\ 56 \text { \& older } & 10 \\ \text { Missing } & 21\end{array}$


When asked how long they had served in jail or prison in their lifetime, 43 inmates indicated six months or less; 15 had served less than a year; 37 claimed to have been incarcerated between one year and five years; 19 stated they had served between 5 and 10 years, and 15 had spent more than 10 years in prison or jails. Thus, the picture that emerged from the Sonoma County Jail was one in which there were fewer inmates under 30 and one that was somewhat more experienced in terms of time served in jails and prisons.

SALT LAKE COUNTY JAIL

In the Salt Lake County Jail, 262 inmates, including 29 women, participated in the study. Of these, 110 had been in $j a i l$ on the instant offense for 31 days or less, 83 had been incarcerated between 31 days to 186 days, and 14 had been in the Salt Lake County Jail for 6 months to one year. Nine others claimed excessive periods of time spent in jail presumably awalting trial but these reports seem suspicious in light of the requirement for a quick and speedy trial.

TABLE V

SALT LAKE COUNTY JAIL

INMATE AGE DISTRIBUTION

$\begin{array}{lr}18-21 & 55 \\ 22-25 & 53 \\ 26-30 & 53 \\ 31-35 & 26 \\ 36-44 & 33 \\ 45-55 & 14 \\ 56 \text { \& older } & 3 \\ \text { Missing } & 25\end{array}$

When asked how long they had been incarcerated over their lifetime, 
76 claimed to have only spent six months or less in jail or prison and another 23 claimed up to one year, 31 indicated that they had served up to 2.5 years, 29 reported to 5 years of incarceration, and 26 respondents indicated time served up to 10 years.

The demographic picture that emerged from these data indicated that the RBJ/MCDC work force was somewhat older and more experienced than in the other two jalls, while the inmate populations were relatively similar except that the RBJ/MCDC group was somewhat younger and less sophisticated in terms of time spent in jail or prison than those in the other two jails.

\section{CIES RESULTS}

The results of the Correctional Institutions Environment Scale Indicated that there were some differences between the jails in 1983 and there were even more significant differences between 1983 and 1984 . For example, for male inmates in RBJ/MCDC, there was an appreciable improvement in the Order and Organization scale from 39.7 in 1983 (RBJ) to 57.0 in 1984 (MCDC). The results for all jails are deplcted in Table VI and Table VII. Inspection of the CIES results reveals that for RBJ/MCDC, average male staff scores as a group, showed a general improvement in social climate scores after the move from RBJ to MCDC. The same appears to hold true for male inmates also, but to a lesser degree. Average inmate and staff scores on the CIES for Sonoma County Jall indicate that staff and inmates differ in their responses, with staff perceiving a more positive social climate than inmates. Average scores for inmates and staff at Salt Lake County Jall reveal a good deal of ambiguity in 
staff and inmate responses regarding social climate. The same general pattern is also true for female inmates and staff.

TABLE VI

CIES SCORES FOR ALL JAILS,

MALE INMATES AND MALE OFFICERS, 1983-1984

$\begin{array}{ccc}\text { Relationship } & \text { Program } & \text { System } \\ \text { Dimension } & \text { Dimension } & \begin{array}{c}\text { Maintenance } \\ \text { Dimension }\end{array}\end{array}$

$\begin{array}{lllllllll}I & \mathrm{~S} & \mathrm{E} & \mathrm{A} & \text { PO } & \text { PPO } & 00 & \mathrm{C} & \text { SC }\end{array}$

\begin{tabular}{llllllrllll}
\hline RBJ/MCDC & & & & & & & & & & \\
Staff & 1983 & 26.0 & 26.7 & 48.2 & 32.8 & 9.5 & 38.6 & 17.7 & 26.7 & 52.5 \\
Staff & 1984 & 49.5 & 51.7 & 46.8 & 38.9 & 25.7 & 46.0 & 61.3 & 53.7 & 53.3 \\
Inmates & 1983 & 41.2 & 34.4 & 47.7 & 42.2 & 26.2 & 42.7 & 39.7 & 43.0 & 49.1 \\
Inmates & 1984 & 41.9 & 36.3 & 45.4 & 36.5 & 27.5 & 39.2 & 57.0 & 50.3 & 53.9
\end{tabular}

SCJ

$\begin{array}{lllllllllll}\text { Staff } & 1983 & 28.2 & 21.0 & 47.6 & 46.6 & 17.7 & 39.1 & 26.2 & 32.8 & 48.6 \\ \text { Staff } & 1984 & 41.0 & 46.0 & 60.8 & 50.0 & 29.8 & 48.7 & 42.6 & 38.2 & 32.7 \\ \text { Inmates } & 1983 & 38.2 & 29.4 & 50.4 & 43.7 & 27.6 & 42.4 & 33.8 & 38.2 & 41.3 \\ \text { Inmates } & 1984 & 45.6 & 34.8 & 56.1 & 43.2 & 24.8 & 41.3 & 30.2 & 41.6 & 39.6\end{array}$

SLC

$\begin{array}{lllllllllll}\text { Staff } & 1983 & 29.6 & 26.1 & 39.3 & 40.1 & 15.4 & 35.3 & 36.6 & 24.0 & 54.7 \\ \text { Staff } & 1984 & 22.6 & 45.0 & 29.0 & 30.6 & 22.6 & 42.3 & 62.3 & 54.3 & 50.6 \\ \text { Inmates } & 1983 & 47.3 & 36.5 & 44.6 & 38.0 & 29.7 & 41.5 & 50.1 & 46.8 & 48.6 \\ \text { Inmates } & 1984 & 49.3 & 37.0 & 48.2 & 41.1 & 28.2 & 42.4 & 49.0 & 45.3 & 46.0\end{array}$


TABLE VII

CIES SCORES FOR ALL JAILS,

FEMALE INMATES AND FEMALE OFFICERS, 1983-1984

Relationship
Dimension
Program

Dimension
System

Maintenance

Dimension

\begin{tabular}{llllllllllll}
\hline & & & & & & & & & & \\
& & & S & E & A & PO & PPO & O0 & C & SC \\
\hline RBJ/MCDC & & & & & & & & & & \\
& & & & & & & & & & \\
Staff & 1983 & 35.2 & 36.0 & 50.0 & 32.3 & 13.2 & 39.7 & 33.0 & 40.0 & 50.2 \\
Staff & 1984 & 60.0 & 62.5 & 62.0 & 47.7 & 31.2 & 57.5 & 67.2 & 60.2 & 51.2 \\
Inmates & 1983 & 38.6 & 33.7 & 38.9 & 33.6 & 30.6 & 41.7 & 45.2 & 46.2 & 63.1 \\
Inmates & 1984 & 42.5 & 33.8 & 40.9 & 34.8 & 29.2 & 35.8 & 51.8 & 51.0 & 61.8 \\
& & & & & & & & & & \\
SCJ & & & & & & & & & & \\
& & & & & & & & & & \\
Staff & 1983 & 34.6 & 23.3 & 55.1 & 45.3 & 18.3 & 42.7 & 28.7 & 23.2 & 48.5 \\
Staff & 1984 & 41.0 & 39.0 & 50.8 & 39.1 & 27.5 & 44.0 & 31.8 & 35.5 & 51.3 \\
Inmates & 1983 & 39.6 & 32.7 & 33.0 & 30.5 & 25.9 & 39.4 & 37.6 & 32.5 & 55.8 \\
Inmates & 1984 & 51.2 & 31.8 & 39.8 & 31.6 & 37.3 & 45.4 & 56.3 & 45.8 & 53.1 \\
& & & & & & & & & & \\
SLC & & & & & & & & & & \\
& & & & & & & & & & \\
Staff & 1983 & 29.9 & 21.0 & 40.3 & 34.4 & 8.7 & 37.9 & 26.0 & 31.5 & 53.3 \\
Staff & 1984 & 40.0 & 55.0 & 45.6 & 35.6 & 49.6 & 44.0 & 69.6 & 67.3 & 68.5 \\
Inmates & 1983 & 46.2 & 33.2 & 40.1 & 42.0 & 35.0 & 41.8 & 52.4 & 40.0 & 54.2 \\
Inmates & 1984 & 42.5 & 32.9 & 40.5 & 28.2 & 30.3 & 36.0 & 47.4 & 44.8 & 60.8
\end{tabular}

As explained earlier, (pp. 64-67), the 90 items of the Form $R$ on the CIES are grouped into nine subscales, of which three assess relationships, three assess programs, and three assess system maintenance. By adding up the desired scores on each dimension one arrives at a raw score which is then converted into a standard score. The average score for one group or jail can then be compared to that for another subgroup or jail and to the national norm.

The primary use of the CIES in general, and in this study specifically, is to obtain social climate measures for the individual jails, to 
compare scores on these measures over time, and to contrast one jail with another.

Rocky Butte Jail: In Rocky Butte Jail in 1983, the overall scores of male staff and inmates indicated they perceived very low Involvement and Support. Subscale averages on the CIES indicate a good deal of improvement on both dimensions after the move into MCDC on the part of staff, but few inmates apparently perceived much improvement. Mean scores on the subscale of Expression were relattvely high for both 1983 and 1984 for both inmates and staff and little change was noted after the move into MCDC. Mean scores on the program dimension showed little agreement between staff and inmates. For example, on the subscale of Autonomy, male staff and inmate averages were separated by nearly 10 points in Rocky Butte Jall, with fewer inmates viewing the jail as providing autonomy. After the move into the MCDC, however, there was nearly complete agreement between staff and inmates on the Autonomy measure. There was also great disparity between staff and inmates in Rocky Butte Jail in 1983 on the subscale of Practical Orientation. Few staff members appeared to regard the jail as providing anything in the way of Practical Orientation, while many inmates apparently believed that there was some value in some of the programs. However, in 1984, there was close agreement between mean scores of male staff and inmates in MCDC, with the greatest improvement in the staff score from 9.5 to 25.7. Contrary to what one would suspect, overall, the inmates and staff were relatively similar on judgments of Personal Problem Orientation. Apparently what counseling programs there were did have an impact on inmate responses. It may be that conditions were so abomin- 
able in RBJ that any attention from staff was felt to be positive. The greatest improvement was noted on the Systems Maintenance dimension. Overall scores on the subscales of Order and Organization and of Clarity improved remarkably after the move into MCDC, or in other words, increased numbers of inmates and staff members responded affirmatively to these subscales. Scores on the subscale of Staff Control remained relatively constant for both male inmates and Staff.

The responses of female staff and inmates at RBJ showed a somewhat different picture. There was rather close agreement between inmates and staff in 1983, before the female inmates moved into the MCDC. The overall scores of staff and inmates were relatively similar regarding Involvement, Support, Autonomy, Personal Problem Orientation, and Clarity subscales, while overall responses to the other subscales showed some disagreement.

However, after the move into the MCDC, increased numbers of staff indicated that they viewed the social climate as positive, except for the subscale of Practical Orientation. Clearly, more female staff reported a positive social climate at the MCDC than did the female inmates.

Sonoma County Jail: There were observed differences in the CIES scores for the two time periods for the Sonoma County Jail, mostly in the direction of moderate improvements in scores for staff and inmates except for the exception of the Relationship dimension. During the period between the first and second administration of the CIES, a new Jail Commander was appointed. His style of fail management evidently contributed to the Improved scores on the part of staff as well as 
inmates. Overall scores on the other two dimensions showed some improvement on the subscales of Practical Orientation, Personal Problem Orientation and Clarity.

Salt Lake County Jail: Overall, the CIES scores on Support, Practical Orientation, and Personal Problem Orientation increased and those on Involvement, Expressiveness and Autonomy decreased on the part of male staff. Male correctional officers also showed overall improvement on the subscales of Order and Organization as well. The mean scores of male inmates, on the other hand, changed very little from 1983 to 1984.

The overall scores of female staff improved on all subscales. These changes ranged from moderate (Autonomy, 34.4 in 1983 to 35.6 in 1984) to substantial (Practical Orientation, 8.7 in 1983 to 49.6 in 1984). Total scores of female inmates on the other hand, exhibited no improvement between the two periods except for Expressiveness (40.1 to 40.5) and Clarity ( 40.0 to 44.8 ). Slightly more staff and inmates judged staff control to be more characteristic of the jail in 1984 than was true in 1983.

Over the study period 1983-1984, the overall CIES scores increased on eight subscales at RBJ/MCDC for male staff and on all nine subscales for female staff. Total scores on six subscales for male inmates increased even though most of the gains were slight, while total scores on seven scales for female inmates increased. These results suggest that the RBJ/MCDC improvements may have occurred because of improved living conditions and because of increased staff supervision and attention. The Improved CIES scores for the Sonoma County Jail may have 
been due to the appointment of a new Jail Commander. The improved scores for the Salt Lake County Jail are more difficult to explain in that the administration reported no executive or supervisory staff changes and no architectural or program changes. One possible explanation may be found in Glaser's ${ }^{3}$ observation that somehow, correctional institutions work most of the time. Every jail or prison administrator will admit that his or her facility will be easily managed for a period of time with few obvious problems, then for some unknown reason, one problem after another will occur. These peaks and valleys in the rhythm of a total institution are a reality with which one must reckon. The administration of the CIES at the Salt Lake County Jail may have coincided first with a low point and then a high point in the life cycle of the institution.

The overall male staff scores for Involvement and Support at RBJ/MCDC improved remarkably. Involvement rose from a score of 26.0 (RBJ) to 49.5 (MCDC) and Support increased from a score of 26.7 (RBJ) to 51.7 (MCDC). There were also significant total score improvements on the scales of Order and Organization, Clarity, and Staff Control. Table VI shows the results for male staff.

CIES subscale averages for female staff indicate that all subscale averages increased from 1983 to 1984 with the exception of Staff Control. Female CIES scores are depicted on Table VII.

The CIES scores of female inmates did not increase as greatly as did those of female staff. The subscales of Order and Organization and Clarity are the exception in that significant increases in average scores are noted for both. 
FIGURE 11

SOCIAL CLIMATE SCALE PROFILE

RBJ/MCDC MALE INMATE AND STAFE

1983-1984

Inmates $\mathrm{RBJ} / \mathrm{MCDC}$

Standard Scores

90

80

70

60

50

40

30

20

10

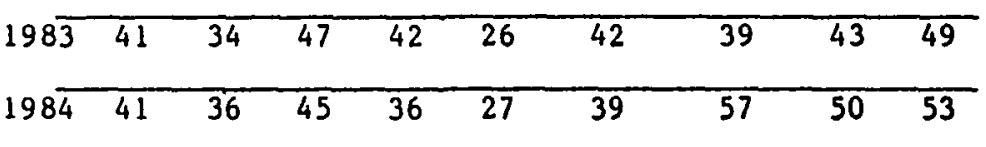

SCALE I S
Staff RBJ/MCDC

Standard Scores

90

80

70

60

50

40

30

20

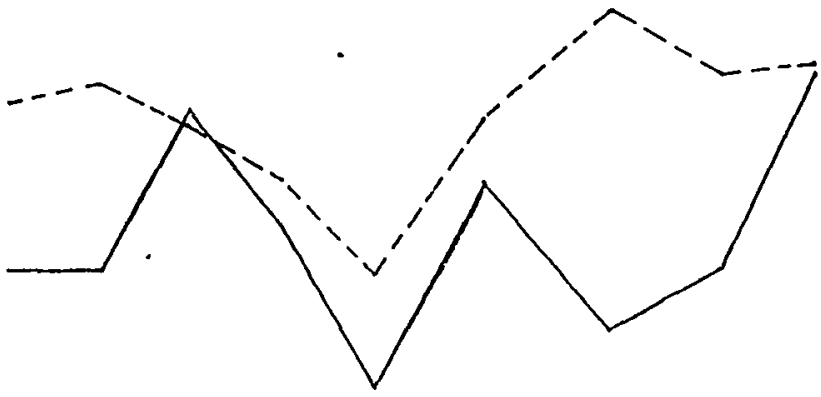

1983

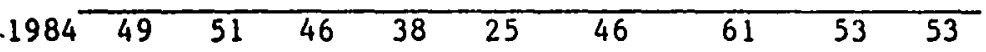

$\begin{array}{lllllllll}\text { SCALE I } & \text { S } & \text { E } & \text { A } & \text { PO } & \text { PPO } & 00 & \text { C } & \text { SC }\end{array}$

RBJ 1983

MCDC 1984 


\section{FIGURE 12}

SOCIAL CLIMATE SCALE PROFILE

RBJ/MCDC FEMALE INMATES AND STAF

1983-1984

Inmates RBJ/MCDC

Standard Scores

90

80

70

60

50

40

30

20

10

$\begin{array}{llllllllll}1983 & 38 & 33 & 38 & 33 & 30 & 41 & 45 & 46 & 63\end{array}$

$\begin{array}{llllllllll}1984 & 42 & 33 & 40 & 34 & 29 & 35 & 51 & 51 & 61\end{array}$

$\begin{array}{lllllllll}\text { SCALE I } & S & \text { E } & \text { A } & \text { PO } & \text { PPO } & 00 & \text { C } & \text { SC }\end{array}$

RBJ 1983

$-\ldots$ MCDC 1984

\section{Staff RBJ/MCDC}

Standard Scores

90

80

70

60

50

40

30

20

1,0

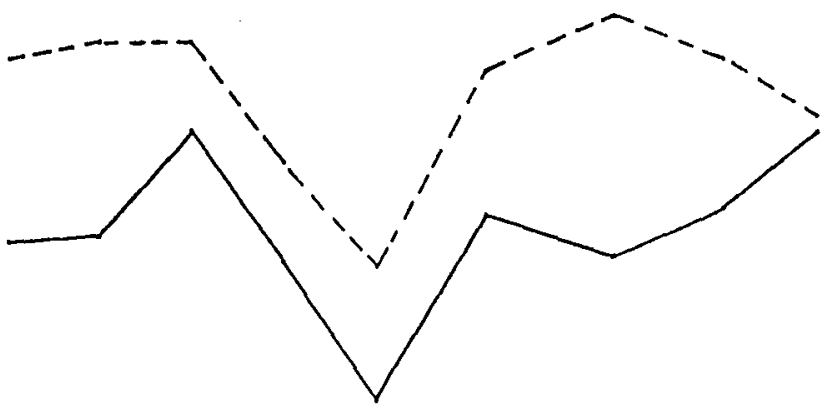

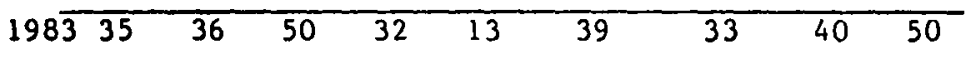

$\begin{array}{lllllllll}1 9 8 \longdiv { 6 0 } & 62 & 62 & 47 & 31 & 57 & 67 & 60 & 51\end{array}$

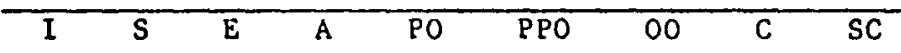


FIGURE 13

SOCIAT. CLIMATE SCALE PROFILE

SONOMA COUNTY JAIL

MALE INMATES AND STAFF

1983-1984

Inmates $\mathrm{SCJ}$

Standard Scores

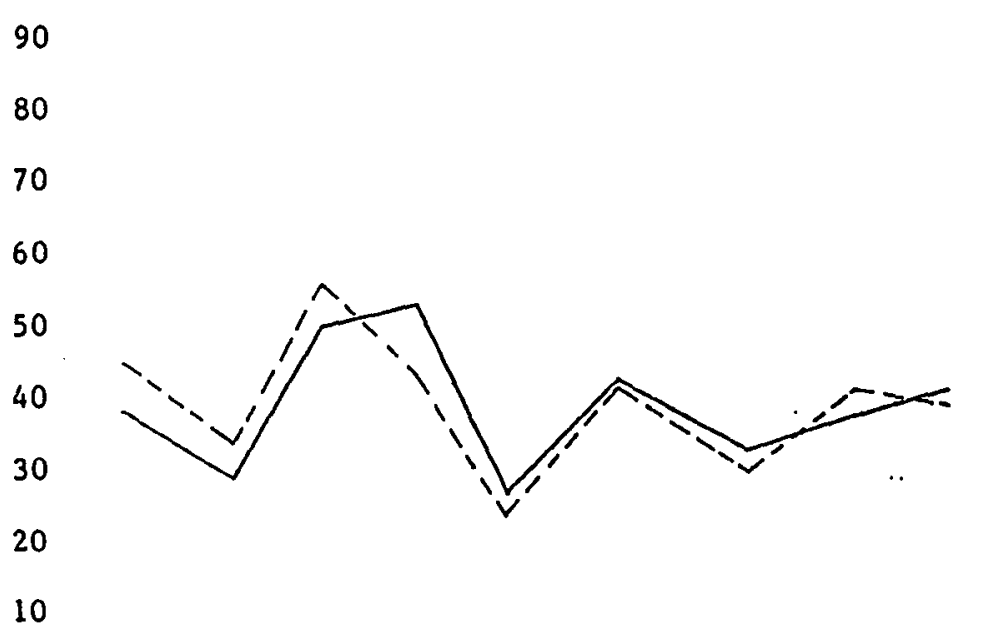

Staff SCJ

Standard Scores

90

80

70

60

50

40

30

20

10

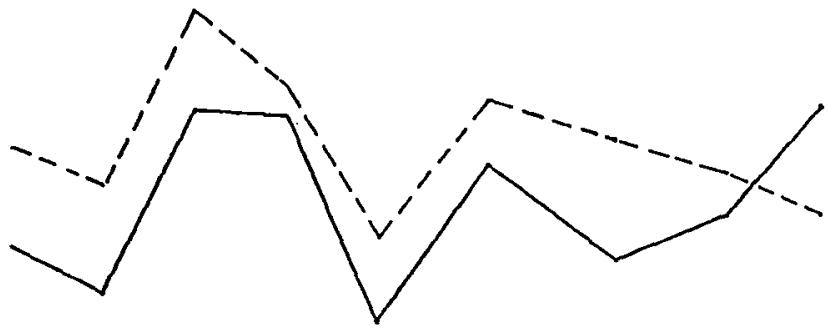

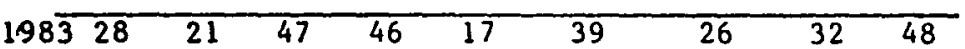

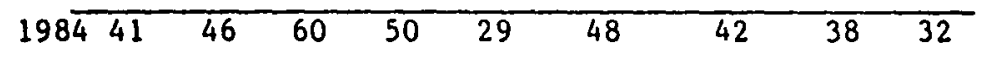

$\begin{array}{lllllllll}\text { SCALE I } & \text { S } & \text { E } & \text { A } & \text { PO } & \text { PPO } & 00 & \text { C } & \text { SC }\end{array}$ SCJ 1983

- $-\ldots \ldots$ SCJ 1984 
FIGURE 14

SOCIAL CLIMATE SCALE PROFILE

SONOMA COUNTY JAIL

FEMALE INMATES AND STAFF

1983-1984

\section{Inmates $\mathrm{SCJ}$ \\ Standard Scores}

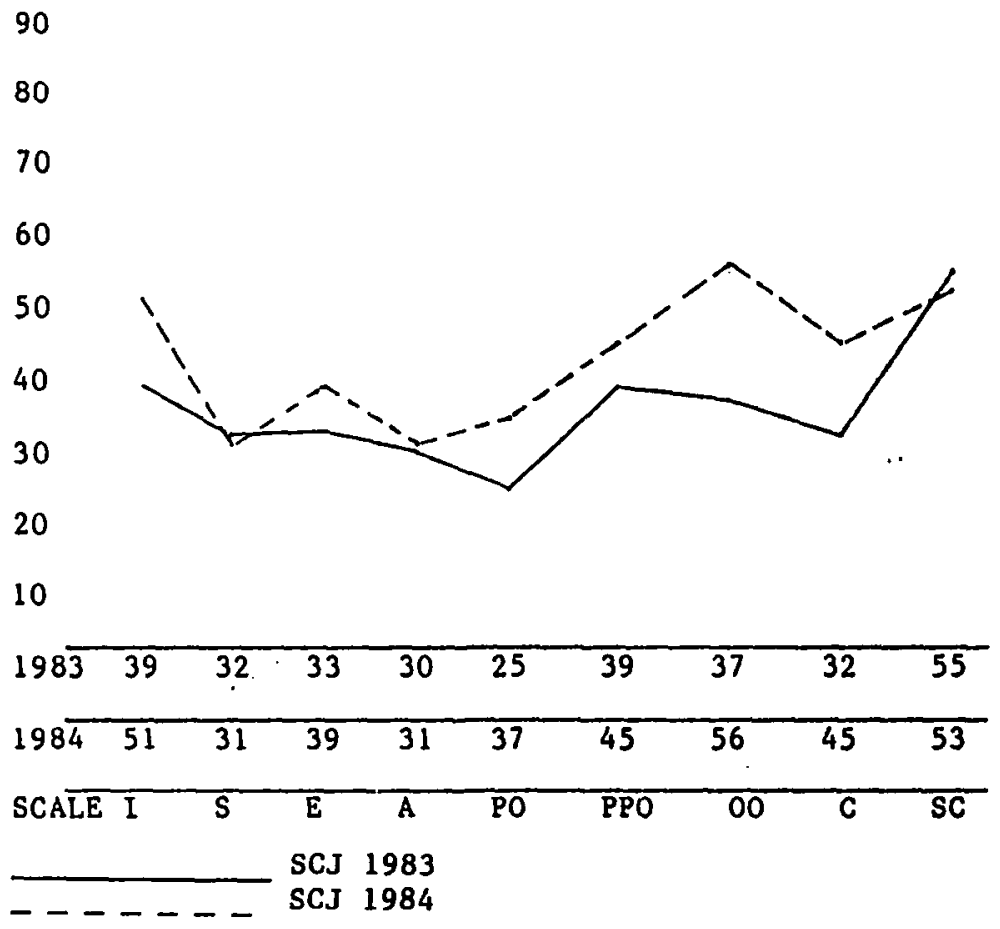

Staff SCJ

Standard Scores

90

80

70

60

50

40

30

20

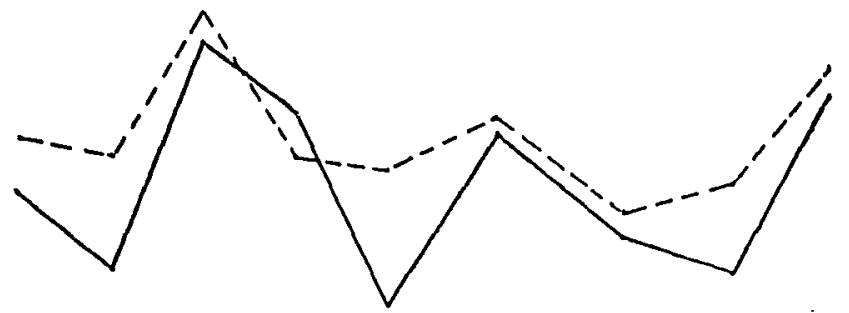

10
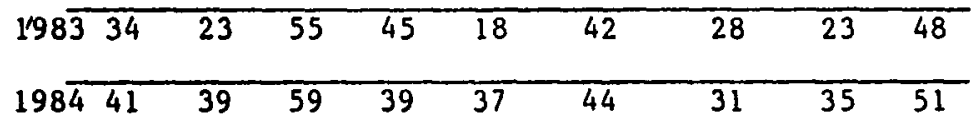

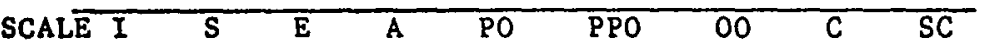


FIGURE 15

SOCIAL CPLIMATE SCALE PROFILE

SALT LAKE COUNTY JAIL

MALE INMATES AND STAFF

1983-1984

Inmates SLC

Stcandard Scores

90

80

70

60

50

40

30

20

10

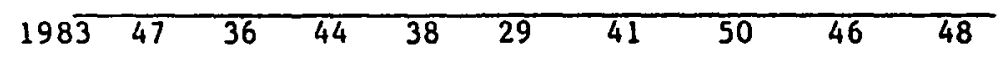

$\begin{array}{llllllllll}1984 & 49 & 37 & 48 & 41 & 28 & 42 & 49 & 45 & 46\end{array}$

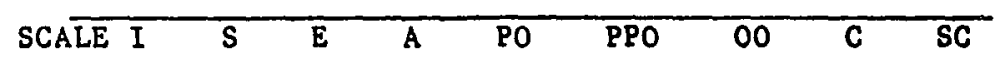

SLC 1983

SLC 1984

\section{Staff SLC}

Standard Scores

90

80

70

60

50

40

30

20

10

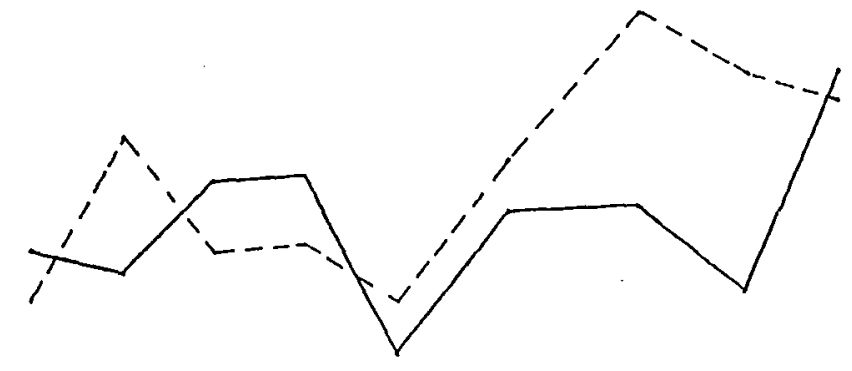

$\begin{array}{lllllllll}1 9 8 \longdiv { 3 } 2 9 & 26 & 39 & 40 & 15 & 35 & 36 & 24 & 54\end{array}$

$\begin{array}{lllllllll}1 9 8 \longdiv { 2 2 } & 45 & 29 & 30 & 22 & 42 & 62 & 54 & 50\end{array}$

$\begin{array}{lllllllll}\text { SCALE I } & \text { S } & \text { E } & \text { A } & \text { PO } & \text { PPO } & \text { O0 } & \text { C } & \text { SC }\end{array}$ 
FIGURE 16

SOCIAL CLIMATE SCALE PROFILE

SALT LAKE COUNTY JAII

FEMALE INMATES AND STAFF

1983-1984

Inmates SLC

Standard Scores

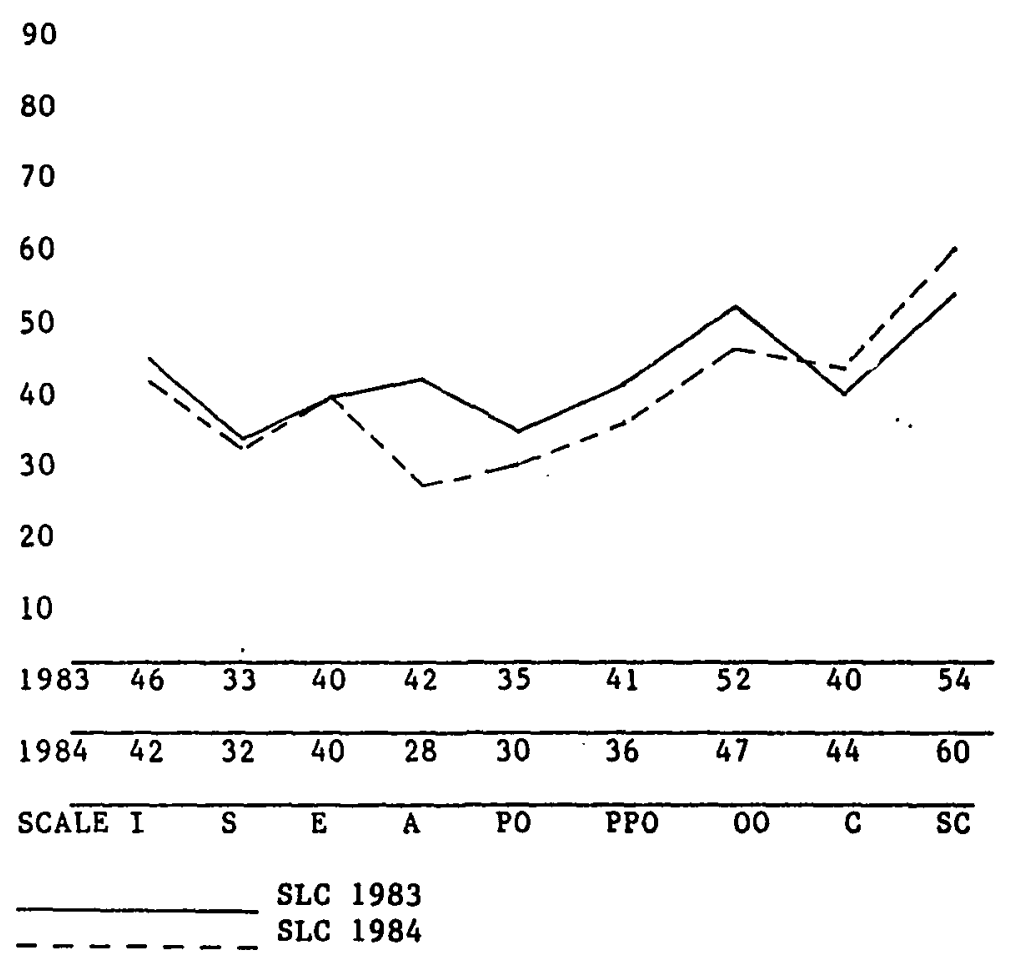

\section{Staff SLC}

Standard Scores

90

80

70

60

50

40

30

20

10

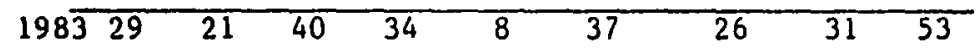

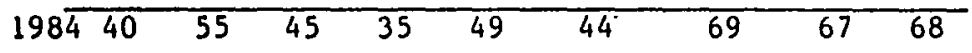

$\begin{array}{lllllllll}\text { SCALE I } & \text { S } & \text { E } & \text { A } & \text { PO } & \text { PPO } & 00 & \text { C } & \text { SC }\end{array}$ 
STATISTICAL ANALYSIS

Data derived from administration of the CIES to inmates and staff at the respective jails have been examined in the preceding pages. However, the CIES scores are only averages for each subscale without an attempt to control for other variables. In our attempt to determine whether or not physical environment is important in perceptions of social climate, we need to control for other influences. Analysis of covariance is one statistical procedure that allows us to control for age, status, sex, time in jail this time and time in jail and prison all one's life.

The second step in the analysis of the data used the analysis of covariance and the results of the data analysis for $R B J / M C D C$ were then compared to those for the two control Jails: Sonoma County Jail and Salt Lake County Jail. Subscale means were obtained from the analysis of covariance and are depicted in the figures that follow. On the left appear possible mean scores and the year is shown at the bottom of the figure. By simply drawing a line between the mean score for 1983 and the mean score for 1984 one can easily see change in perceptions of social climate between the two test periods after analysis of covariance has controlled for the covariates.

Earlier it was explained that the Analysis of Covariance is performed by first doing a multiple linear regression by rolling the covariates (status, age, sex, $\mathrm{T}_{1}$ and $\mathrm{T}_{2}$ ) onto the experimental variable Jail. An Analysis of Variance is then performed on the residuals and the results are then interpreted through an F-score. In this procedure, 
staff and inmate, male and female scores were aggregated to arrive at an overall picture of the degree of change. For example, in Figure 17 the 1983 mean score after Analysis of Covariance is 37.4 and a mean score of 43 is noted for 1984. We see that there was an increase in perceptions of a positive social climate in MCDC when we controlled for the covariates. By glancing ahead to Table VIII we note that the improvement is significant to .005 or better for jail and year. 
FIGURE 17

\section{ANALYSIS OF COVARIANCE \\ STAFF AND INMATES \\ INVOLVEMENT}

$\begin{array}{ll}\text { Mean Standard } & \\ \text { Scores } & \\ 60 & 60 \\ 55 & 55 \\ 50 & 50 \\ 45 & 45 \\ 40 & 40 \\ 35 & 35 \\ 30 & 30 \\ 25 & 25 \\ 20 & 20 \\ 15 & 15\end{array}$

1983 
FIGURE 18

\section{ANALYSIS OF COVARIANCE \\ STAFF AND INMATES \\ SUPPORT}

Mean Standard

Score

60

55

50

50

45

40

35

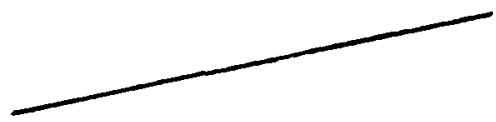

40

35

30

30

25

25

20

20

15

15

1983

1984 


\section{FIGURE 19}

\section{ANALYSIS OF COVARIANCE \\ STAFF AND INMATES \\ EXPRESSIVENESS}

$\begin{array}{ll}\begin{array}{ll}\text { Mean Standard } \\ \text { Score }\end{array} & \\ 60 & 60 \\ 55 & 55 \\ 50 & 50 \\ 45 & 45 \\ 40 & 40 \\ 35 & 35 \\ 30 & 30 \\ 25 & 25 \\ 20 & 20 \\ 15 & 15\end{array}$

1983

1984 
FIGURE 20

\section{ANALYSIS OF COVARIANCE \\ STAFF AND INMATES AUTONOMY}

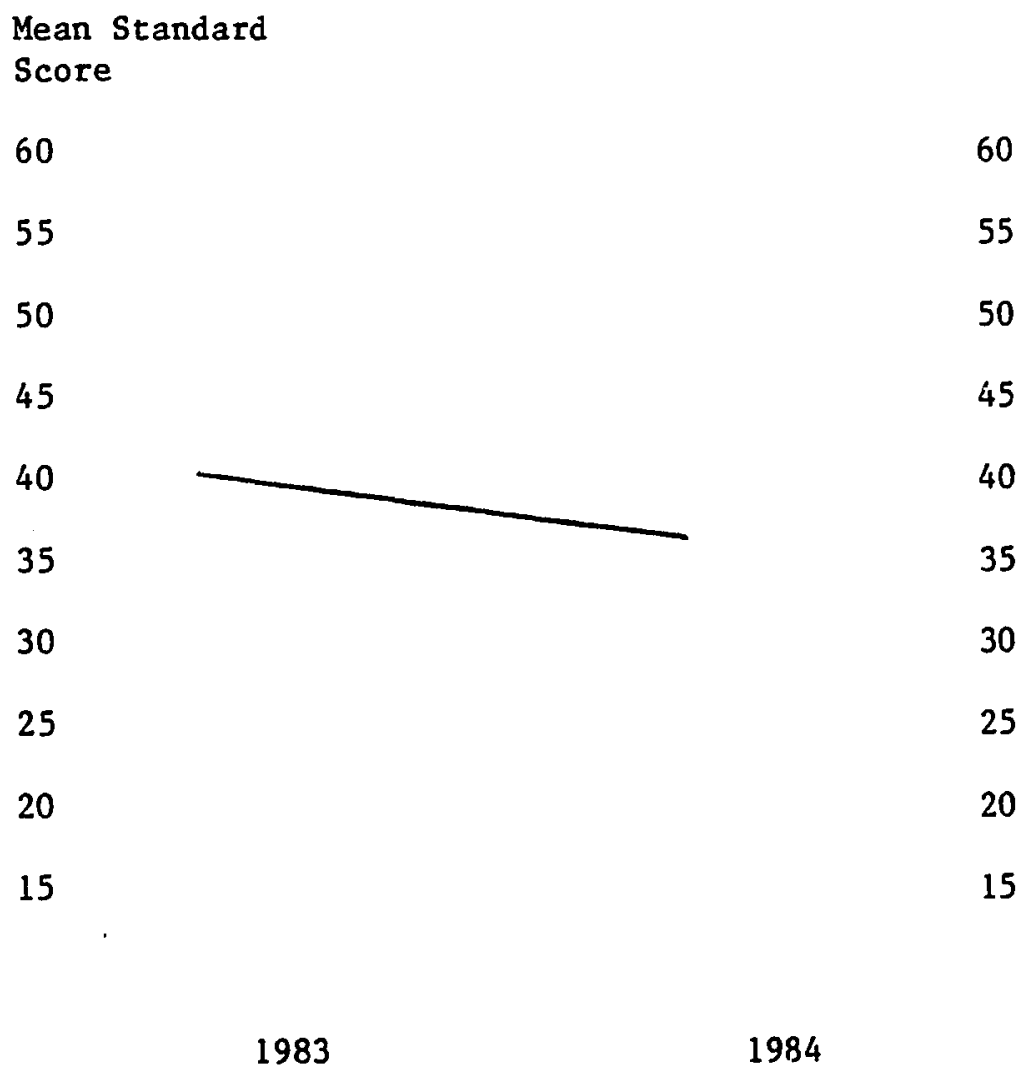


FIGURE 21

ANALYSIS OF COVARIANCE

STAFF AND INMATES

PRACTICAL ORIENTATION

$\begin{array}{ll}\text { Mean Standard } & \\ \text { Score } & \\ 60 & 60 \\ 55 & 55 \\ 50 & 50 \\ 45 & 45 \\ 40 & 40 \\ 35 & 35 \\ 30 & 30 \\ 25 & 25 \\ 20 & 20 \\ 15 & 15\end{array}$

1983

1984 
FIGURE 22

ANALYSIS OF COVARIANCE

STAFF AND INMATES

PERSONAL PROBLEM ORIENTATION

Mean Standard

Score

60

60

55

55

50

.50

45

45

40

40

35

35

30

30

25

25

20

20

15

15

1983

1984 
FIGURE 23

ANALYSIS OF COVARIANCE

STAFF AND INMATES

ORDER AND ORGANIZATION

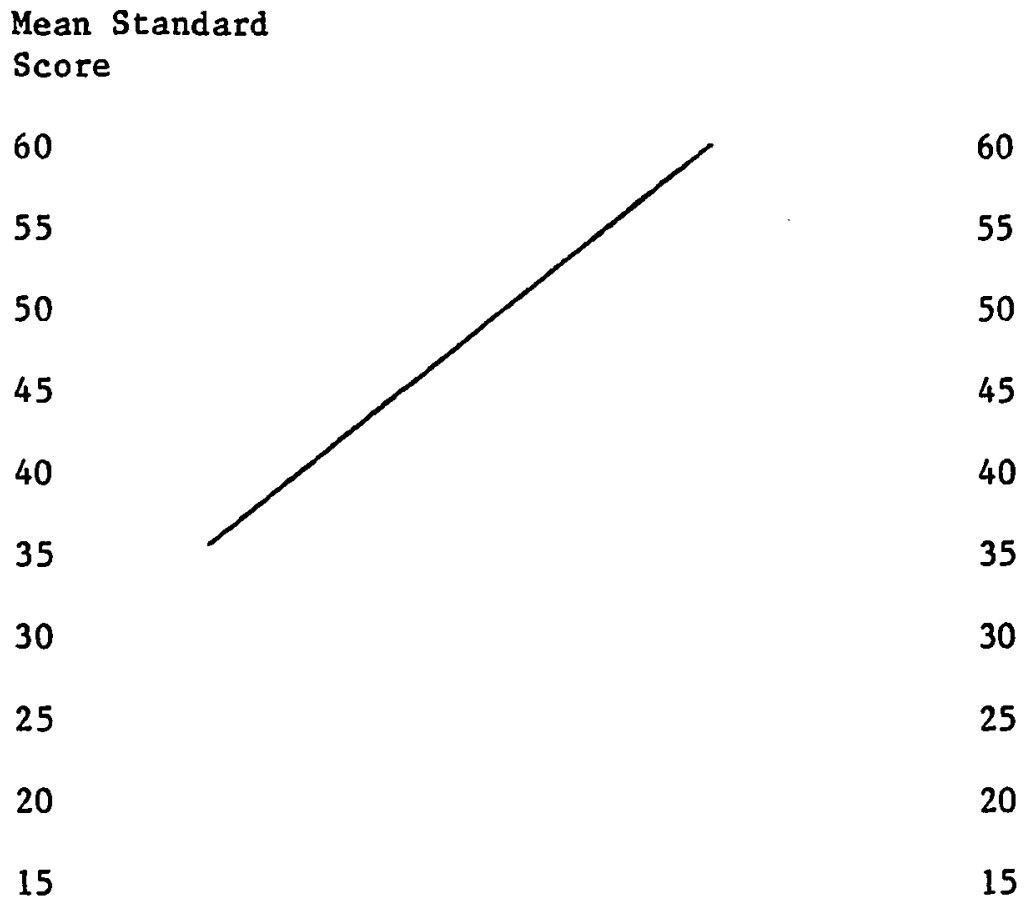

1983

1984 
FIGURE 24

ANALYSIS OF COVARIANCE

STAFF AND INMATES

CLARITY

\section{Mean Standard}

Score

60

60

55

50

45

40

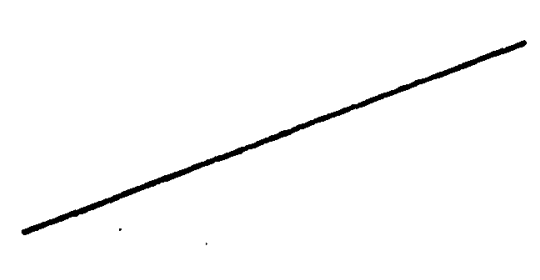

35

30

30

25

25

20

20

15

55

50

45

40

35

15 
FIGURE 25

\section{ANALYSIS OF COVARIANCE \\ STAFF AND INMATES \\ STAFF CONTROL}

Mean Standard

Score

60

60

55

55

50

50

45

45

40

40

35

35

30

30

25

25

20

20

15

15

1983

1984 
There was significant improvement of total scores in six scales in $\mathrm{RBJ} / \mathrm{MCDC}$ and this improvement was significant in relation to the other two jails. After an analysis of the subscale of Involvement, the main effects of Jail, Year and Age were regressed upon the covariates of Status, Sex, $T_{1}$ and $T_{2}$ and it was determined that Jail and Year were significant at the .001 and .002 level respectively. Age was not significant. For the subscale of Support, Year was significant at the .001 level. Upon examination of the data for the subscales of Expressiveness, Autonomy, and Practical Orientation, age was found to be significant at the .001 level for all three subscales. No significant change was found for the subscale of Personal Problem Orientation. Scores on Order and Organization were found to be significant for Jail, Year and Age at the .001 level, while Year was significant at the .001 level for Clarity and jail was significant with a .005 level for Jail.

Thus it appears that an increased number of the inmates and staff in their mid-twenties and older responded positively in 1984 to the subscales of Involvement and Support and it appears that the move from RBJ to MCDC made the difference. When we compare RBJ/MCDC to the control jalls, little change was noted. However, little improvement in scores is revealed in the control jails when we compare 1983 to 1984.

As noted earlier, the use of ANCOVA allows one to control for the effects of the covariates of status, age, sex, $T_{1}$, and $T_{2}$ on the dependent variable $\mathrm{RBJ} / \mathrm{MCDC}$. The results of the analysis are depicted in Figures 17-25 and Table VIII-XVI. In the Tables that follow, the subscales are identified as I, S, E, A, PO, PPO, 00, C, SC, under which 
is noted the way in which the covariates were regressed upon the dependent variable, (YR and Jail) for the scale, e.g. Involvement. The covariates are then listed, followed by main effects. An F score appears to the right of main effects of Jail and Year and to its right, the significance level of F. For this study, a level of significance of .005 or better was established.

TABLE VIII

ANCOVA

INVOLVEMENT

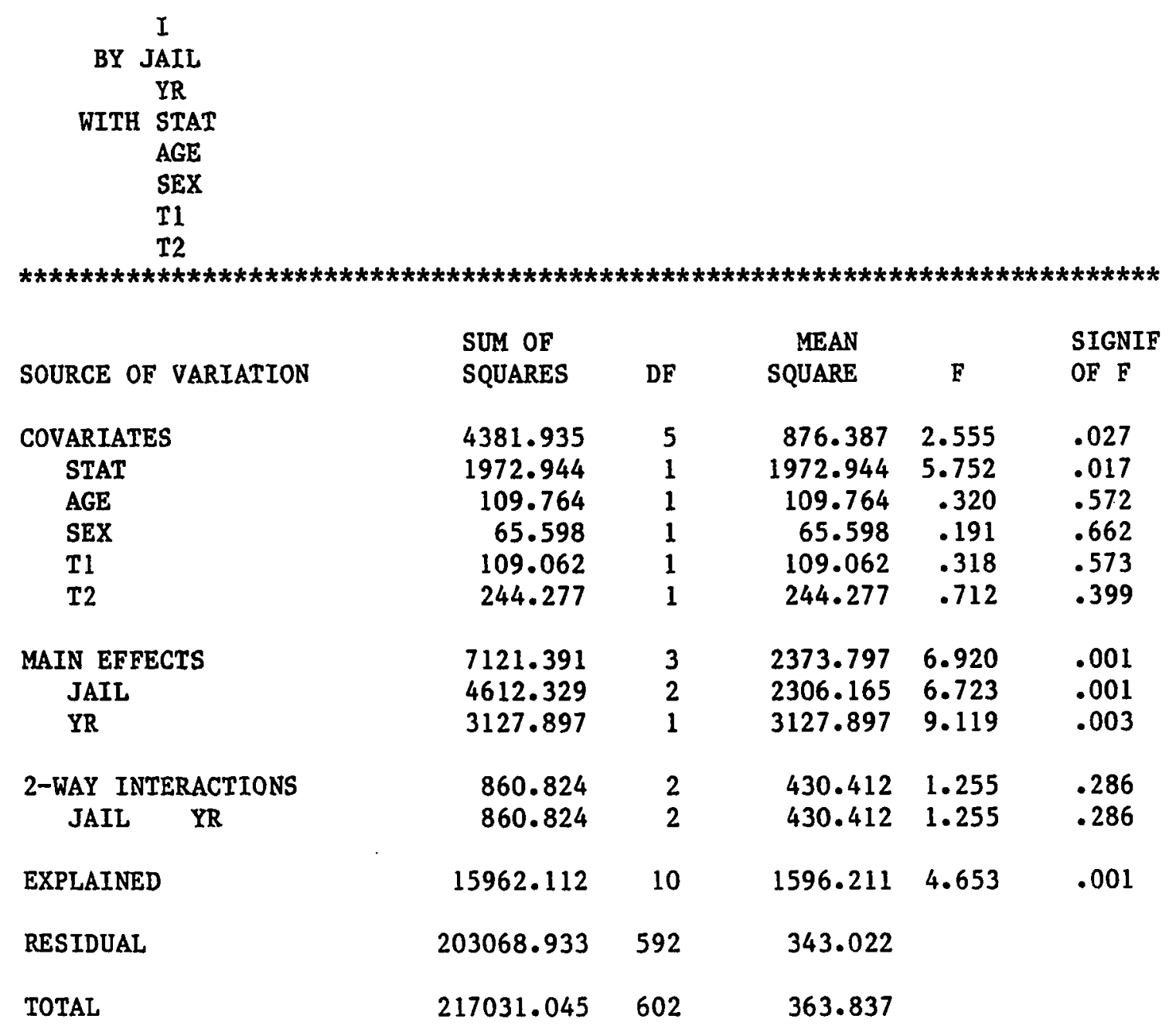


Clearly, year and jail were significant. For jail, involvement was significant at the .001 level and for year at the .003 level of significance. As illustrated in Table VII, we note that all three jails improved, as evidenced by a significance level of .001 for the main effects of Jail and Year.

\section{TABLE IX}

ANCOVA

SUPPORT

S
BY JAIL
YR
WITH STAT
AGE
SEX
T1
T2

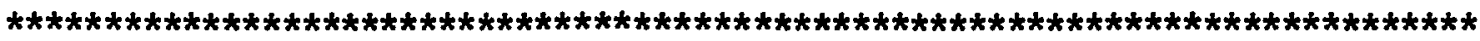

SOURCE OF VARIATION

COVARIATES

STAT

AGE .

SEX

T1

T2

MAIN EFFECTS

JAIL

YR

2-WAY INTERACTION
JAIL YR

EXPLAINED

RESIDUAL

TOTAL

SUM OF
SQUARES
1202.091
627.637
14.210
271.143
739.401
4.125
10197.670
3316.207
7285.364

DF

MEAN
SQUARE

F

SIGNIF

OF $\mathrm{F}$

240.418

627.637

14.210

271.143

739.401

4.125

3399.223

1658.104

7285.364

.634

1.654

.037

.715

1.949

.011

8.959

4.370

19.202

.674

.199

.847

.398

.163

.917

.001

.013

.001

$\begin{array}{lllll}981.840 & 2 & 490.920 & 1.294 & .275\end{array}$

$\begin{array}{lllll}981.840 & 2 & 490.920 & 1.294 & .275\end{array}$

$\begin{array}{lllll}12370.199 & 10 & 1237.020 & 3.260 & .001\end{array}$

$224613.413 \quad 592 \quad 379.415$

$\begin{array}{lll}236983.612 & 602 & 393.660\end{array}$ 


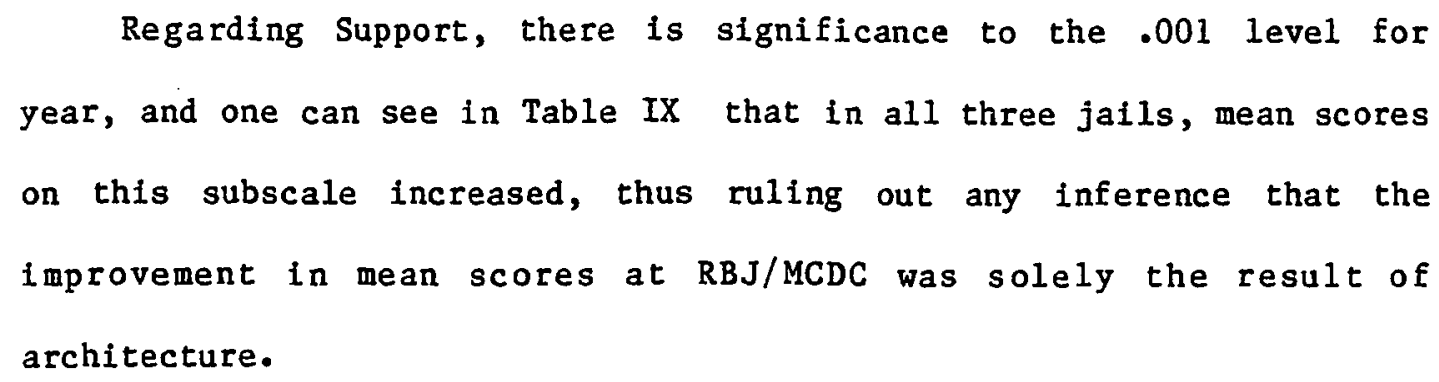

TABLE $X$

ANCOVA

EXPRESSIVENESS

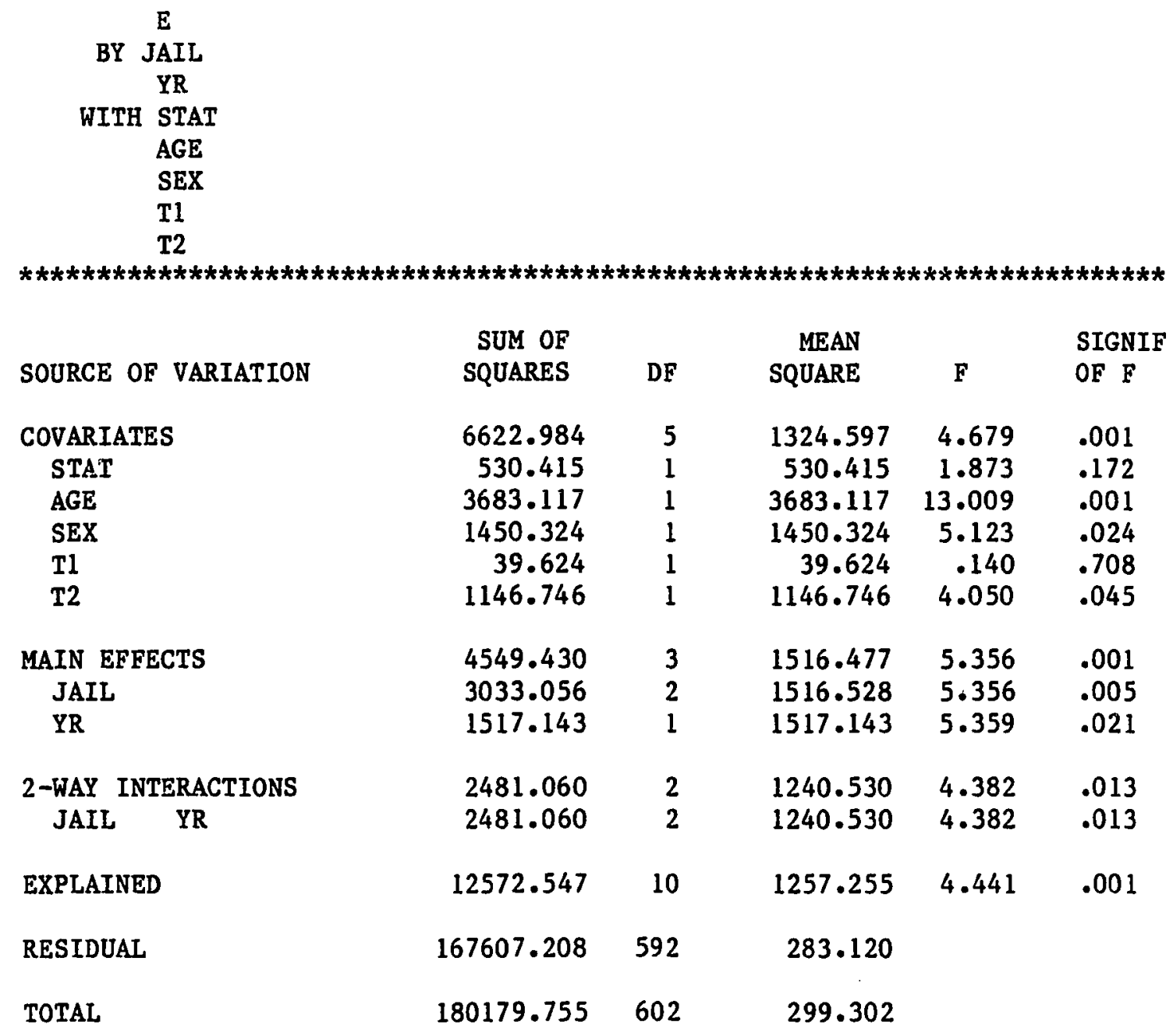


As indicated by Figure 19 and Table X, Expressiveness was significant at the .005 level in the case of the Sonoma County Jail, which may be attributed to a change in Jail Commander and concomitant alterations in jail policy. The improvement in the perception of social climate appears to be more on the part of staff than on the part of the inmates.

TABLE XI

ANCOVA

AUTONOMY

\begin{aligned} \multicolumn{1}{c}{ A } \\ BY JAIL \\ YR \\ WITH STAT \\ AGE \\ SEX \\ T1 \\ T2 \end{aligned}

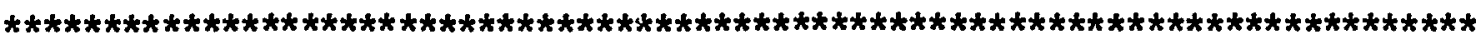

\begin{tabular}{|c|c|c|c|c|c|}
\hline SOURCE VARIATION & $\begin{array}{r}\text { SUM OF } \\
\text { SQUARES }\end{array}$ & DF & $\begin{array}{r}\text { MEAN } \\
\text { SQUARE }\end{array}$ & F & $\begin{array}{l}\text { SIGNIF } \\
\text { OF F }\end{array}$ \\
\hline $\begin{array}{l}\text { COVARIATES } \\
\text { STAT } \\
\text { AGE } \\
\text { SEX } \\
\text { T1 } \\
\text { T2 }\end{array}$ & $\begin{array}{r}12808.595 \\
415.712 \\
7967.556 \\
2915.195 \\
28.018 \\
29.016\end{array}$ & $\begin{array}{l}5 \\
1 \\
1 \\
1 \\
1 \\
1\end{array}$ & $\begin{array}{r}2561.719 \\
415.712 \\
7967.556 \\
2915.195 \\
28.018 \\
29.016\end{array}$ & $\begin{array}{r}7.341 \\
1.191 \\
22.832 \\
8.354 \\
.080 \\
.083\end{array}$ & $\begin{array}{l}.001 \\
.276 \\
.001 \\
.004 \\
.777 \\
.773\end{array}$ \\
\hline $\begin{array}{l}\text { MAIN EFFECTS } \\
\text { JAIL } \\
\text { YR }\end{array}$ & $\begin{array}{r}3356.732 \\
3349.308 \\
5.409\end{array}$ & $\begin{array}{l}3 \\
2 \\
1\end{array}$ & $\begin{array}{r}1118.911 \\
1674.654 \\
5.409\end{array}$ & $\begin{array}{r}3.206 \\
4.799 \\
.015\end{array}$ & $\begin{array}{l}.023 \\
.009 \\
.901\end{array}$ \\
\hline $\begin{array}{c}\text { 2-WAY INTERACTIONS } \\
\text { JAIL } \quad \text { YR }\end{array}$ & $\begin{array}{l}91.985 \\
91.985\end{array}$ & $\begin{array}{l}2 \\
2\end{array}$ & $\begin{array}{l}45.992 \\
45.992\end{array}$ & $\begin{array}{l}.132 \\
.132\end{array}$ & $\begin{array}{l}.877 \\
.877\end{array}$ \\
\hline EXPLAINED & 15757.275 & 10 & 1575.727 & 4.515 & .001 \\
\hline RESIDUAL & 206591.233 & 592 & 340.972 & & \\
\hline TOTAL & 222348.507 & 602 & 369.350 & & \\
\hline
\end{tabular}


Changes in mean scores on the subscale Autonomy were not significant for year or jail. However, changes in scores by age and sex did show significance at the .001 and .004 levels respectively. As shown in Figures 17-25, mean scores at RBJ/MCDC and Salt lake county declined somewhat, while Sonoma County improved.

TABLE XII

ANCOVA

PRACTICAL ORIENTATION

\begin{aligned} \multicolumn{1}{c}{ PO } \\ BY JAIL \\ YR \\ WITH STAT \\ AGE \\ SEX \\ T1 \\ T2 \end{aligned}

\begin{tabular}{|c|c|c|c|c|c|}
\hline SOURCE OF VARIATION & $\begin{array}{l}\text { SUM OF } \\
\text { SQUARES }\end{array}$ & $\mathrm{DF}$ & $\begin{array}{r}\text { MEAN } \\
\text { SQUARE }\end{array}$ & F & $\begin{array}{l}\text { SIGNI } \\
\text { OF F }\end{array}$ \\
\hline $\begin{array}{l}\text { COVARIATES } \\
\text { STAT } \\
\text { AGE } \\
\text { SEX } \\
\text { T1 } \\
\text { T2 }\end{array}$ & $\begin{array}{r}11635.745 \\
2183.877 \\
3505.353 \\
834.763 \\
83.358 \\
7.604\end{array}$ & $\begin{array}{l}5 \\
1 \\
1 \\
1 \\
1 \\
1\end{array}$ & $\begin{array}{r}2327.147 \\
2183.877 \\
3505.353 \\
834.763 \\
83.358 \\
7.604\end{array}$ & $\begin{array}{r}10.585 \\
9.933 \\
15.944 \\
3.797 \\
.379 \\
.035\end{array}$ & $\begin{array}{l}.001 \\
.002 \\
.001 \\
.052 \\
.538 \\
.853\end{array}$ \\
\hline $\begin{array}{l}\text { MAIN EFFECTS } \\
\text { JAIL } \\
\text { YR }\end{array}$ & $\begin{array}{r}1528.129 \\
744.978 \\
924.696\end{array}$ & $\begin{array}{l}3 \\
2 \\
1\end{array}$ & $\begin{array}{l}509.376 \\
372.489 \\
924.696\end{array}$ & $\begin{array}{l}2.317 \\
1.694 \\
4.206\end{array}$ & $\begin{array}{l}.075 \\
.185 \\
.041\end{array}$ \\
\hline $\begin{array}{c}\text { 2-WAY INTERACTIONS } \\
\text { JAIL } \quad \text { YR }\end{array}$ & $\begin{array}{l}359.760 \\
359.760\end{array}$ & $\begin{array}{l}2 \\
2\end{array}$ & $\begin{array}{l}179.880 \\
179.880\end{array}$ & $\begin{array}{l}.818 \\
.818\end{array}$ & $\begin{array}{l}.442 \\
.442\end{array}$ \\
\hline EXPLAINED & 15386.065 & 10 & 1538.607 & 6.998 & .001 \\
\hline RESIDUAL & 130151.809 & 592 & 219.851 & & \\
\hline TOTAL & 145537.874 & 602 & 241.757 & & \\
\hline
\end{tabular}




\author{
TABLE XIII \\ ANCOVA \\ PERSONAL PROBLEM ORIENTATION
}

$\begin{aligned} & \text { PPO } \\ & \text { BY JAIL } \text { YR } \\ & \text { WITH STAT } \text { AGE } \\ & \text { SEX } \\ & \text { T1 } \\ & \text { T2 }\end{aligned}$

\begin{tabular}{|c|c|c|c|c|c|}
\hline SOURCE VARIATION & $\begin{array}{l}\text { SUM OF } \\
\text { SQUARES }\end{array}$ & $\mathrm{DF}$ & $\begin{array}{r}\text { MEAN } \\
\text { SQUARE }\end{array}$ & $\mathbf{F}$ & $\begin{array}{l}\text { SIGNIF } \\
\text { OF F }\end{array}$ \\
\hline $\begin{array}{l}\text { COVARIATES } \\
\text { STAT } \\
\text { AGE } \\
\text { SEX } \\
\text { T1 } \\
\text { T2 }\end{array}$ & $\begin{array}{r}573.017 \\
6.716 \\
7.493 \\
66.229 \\
34.295 \\
198.432\end{array}$ & $\begin{array}{l}5 \\
1 \\
1 \\
1 \\
1 \\
1\end{array}$ & $\begin{array}{r}114.603 \\
6.716 \\
7.493 \\
66.229 \\
34.295 \\
198.432\end{array}$ & $\begin{array}{r}.697 \\
.041 \\
.046 \\
.403 \\
.209 \\
1.207\end{array}$ & $\begin{array}{l}.626 \\
.840 \\
.831 \\
.526 \\
.648 \\
.272\end{array}$ \\
\hline $\begin{array}{l}\text { MAIN EFFECTS } \\
\text { JAIL } \\
\text { YR }\end{array}$ & $\begin{array}{r}171.048 \\
163.819 \\
11.925\end{array}$ & $\begin{array}{l}3 \\
2 \\
1\end{array}$ & $\begin{array}{l}57.016 \\
81.910 \\
11.925\end{array}$ & $\begin{array}{r}.347 \\
.498 \\
.073\end{array}$ & $\begin{array}{l}.792 \\
.608 \\
.788\end{array}$ \\
\hline $\begin{array}{l}\text { 2-WAY INTERACTIONS } \\
\text { JAIL - YR }\end{array}$ & $\begin{array}{l}341.586 \\
341.586\end{array}$ & $\begin{array}{l}2 \\
2\end{array}$ & $\begin{array}{l}170.793 \\
170.793\end{array}$ & $\begin{array}{l}1.038 \\
1.038\end{array}$ & $\begin{array}{l}.355 \\
.355\end{array}$ \\
\hline EXPLAINED & 1046.358 & 10 & 104.636 & .636 & .783 \\
\hline RESIDUAL & 97363.105 & 592 & 164.465 & & \\
\hline TOTAL & 98409.463 & 602 & 163.471 & & \\
\hline
\end{tabular}


For both Practical Orientation (Table XII) and Personal Problem Orientation (Table XIII) score differences between jails and between years were insignificant.

TABLE XIV

ANCOVA
ORDER AND ORGANIZATION

OO
BY JAIL
YR
WITH STAT
AGE
SEX
T1
T2

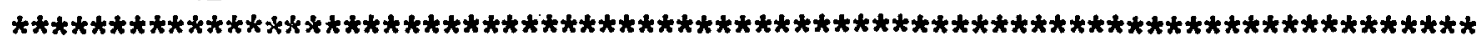

\begin{tabular}{|c|c|c|c|c|c|}
\hline SOURCE OF VARIATION & $\begin{array}{l}\text { SUM OF } \\
\text { SQUARES }\end{array}$ & DF & $\begin{array}{r}\text { MEAN } \\
\text { SQUARE }\end{array}$ & $\mathrm{F}$ & $\begin{array}{l}\text { SIGNIF } \\
\text { OF F }\end{array}$ \\
\hline $\begin{array}{l}\text { COVARIATES } \\
\text { STAT } \\
\text { AGE } \\
\text { SEX } \\
\text { T1 } \\
\text { T2 }\end{array}$ & $\begin{array}{r}7376.273 \\
856.779 \\
22.015 \\
47.731 \\
2248.676 \\
31.155\end{array}$ & $\begin{array}{l}5 \\
1 \\
1 \\
1 \\
1 \\
1\end{array}$ & $\begin{array}{r}1475.255 \\
856.779 \\
22.015 \\
47.731 \\
2248.676 \\
31.155\end{array}$ & $\begin{array}{r}4.109 \\
2.386 \\
.061 \\
.133 \\
6.263 \\
.087\end{array}$ & $\begin{array}{l}.001 \\
.123 \\
.805 \\
.716 \\
.013 \\
.768\end{array}$ \\
\hline $\begin{array}{l}\text { MAIN EFFECTS } \\
\text { JAIL } \\
\text { YR }\end{array}$ & $\begin{array}{l}31869.627 \\
21105.192 \\
11224.435\end{array}$ & $\begin{array}{l}3 \\
2 \\
1\end{array}$ & $\begin{array}{l}10623.209 \\
10552.596 \\
11224.435\end{array}$ & $\begin{array}{l}29.585 \\
29.387 \\
31.260\end{array}$ & $\begin{array}{l}.001 \\
.001 \\
.001\end{array}$ \\
\hline $\begin{array}{c}\text { 2-WAY INTERACTIONS } \\
\text { JAIL }\end{array}$ & $\begin{array}{l}15317.156 \\
15317.156\end{array}$ & $\begin{array}{l}2 \\
2\end{array}$ & $\begin{array}{l}7658.578 \\
7658.578\end{array}$ & $\begin{array}{l}21.329 \\
21.329\end{array}$ & $\begin{array}{l}.001 \\
.001\end{array}$ \\
\hline EXPLAINED & 68956.524 & 10 & 6895.652 & 19.204 & .001 \\
\hline RESIDUAL & 212568.342 & 592 & 359.068 & & \\
\hline TOTAL & 281524.866 & 602 & 467.649 & & \\
\hline
\end{tabular}


TABLE XV

ANCOVA

CLARITY

\begin{aligned} & \multicolumn{1}{c}{ C } \\ & BY JAIL \\ & YR \\ & WITH STAT \\ & AGE \\ & SEX \\ & T1 \\ & T2 \end{aligned}

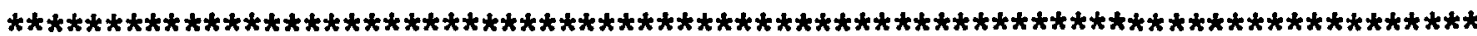

\begin{tabular}{lrrrrr} 
SOURCE OF VARIATION & SUM OF & \multicolumn{1}{c}{ MEAN } & \multicolumn{1}{c}{ SIGNIF } \\
& SQUARES & DF & SQUARE & \multicolumn{1}{l}{ F } & \multicolumn{1}{c}{ OF F } \\
COVARIATES & 10803.421 & 5 & 2160.684 & 6.167 & .001 \\
$\quad$ STAT & 257.536 & 1 & 257.536 & .735 & .392 \\
AGE & 1245.072 & 1 & 1245.072 & 3.554 & .060 \\
SEX & 270.684 & 1 & 270.684 & .773 & .380 \\
T1 & 2016.664 & 1 & 2016.664 & 5.756 & .017 \\
T2 & 205.032 & 1 & 205.032 & .585 & .445 \\
MAIN EFFECTS & 11447.090 & 3 & 3015.697 & 10.891 & .001 \\
$\quad$ JAIL & 3786.528 & 2 & 1893.264 & 5.404 & .005 \\
YR & 7270.597 & 1 & 7270.597 & 20.753 & .001 \\
2-WAY INTERACTIONS & 2267.564 & 2 & 1133.782 & 3.236 & .040 \\
JAIL & 2267.564 & 2 & 1133.782 & 3.236 & .040 \\
YR & 28632.847 & 10 & 2863.285 & 8.173 & .001 \\
EXPLAINED & 207406.018 & 592 & 350.348 & & \\
RESIDUAL & 236038.866 & 602 & 392.091 & & \\
TOTAL & & & & &
\end{tabular}


Changes in mean scores on the Order and Organization and Clarity subscales were significant for both jail and year. In consulting Table XVII-XXV, Figure 8-15, and Figure 23-24, it can be seen that MCDC respondents that agreed that there was a more positive social climate in MCDC in 1984 than believed that there was a positive social climate in RBJ in 1983. This may be attributable not only to the pleasantness of the surroundings, but also to the precision and clarity of polictes and procedures that govern every facet of the daily life of the jall. Clear and concise policies and procedures were practically nonexistent in RBJ, while detalled polices and procedures were produced by the Tramsition Team in over nine months of planning and writing by the Transition Team prior to the opening of the MCDC. As evidenced by a significance level of .001 for jail and year for the scale of Order and Organization, and .005 for jail and .001 for year on the scale of Clarity, inmates and staff both seemed to appreciate the presence of sound policies and coherent, understandable procedures. 
TABLE XVI

ANCOVA

STAFF CONTROL

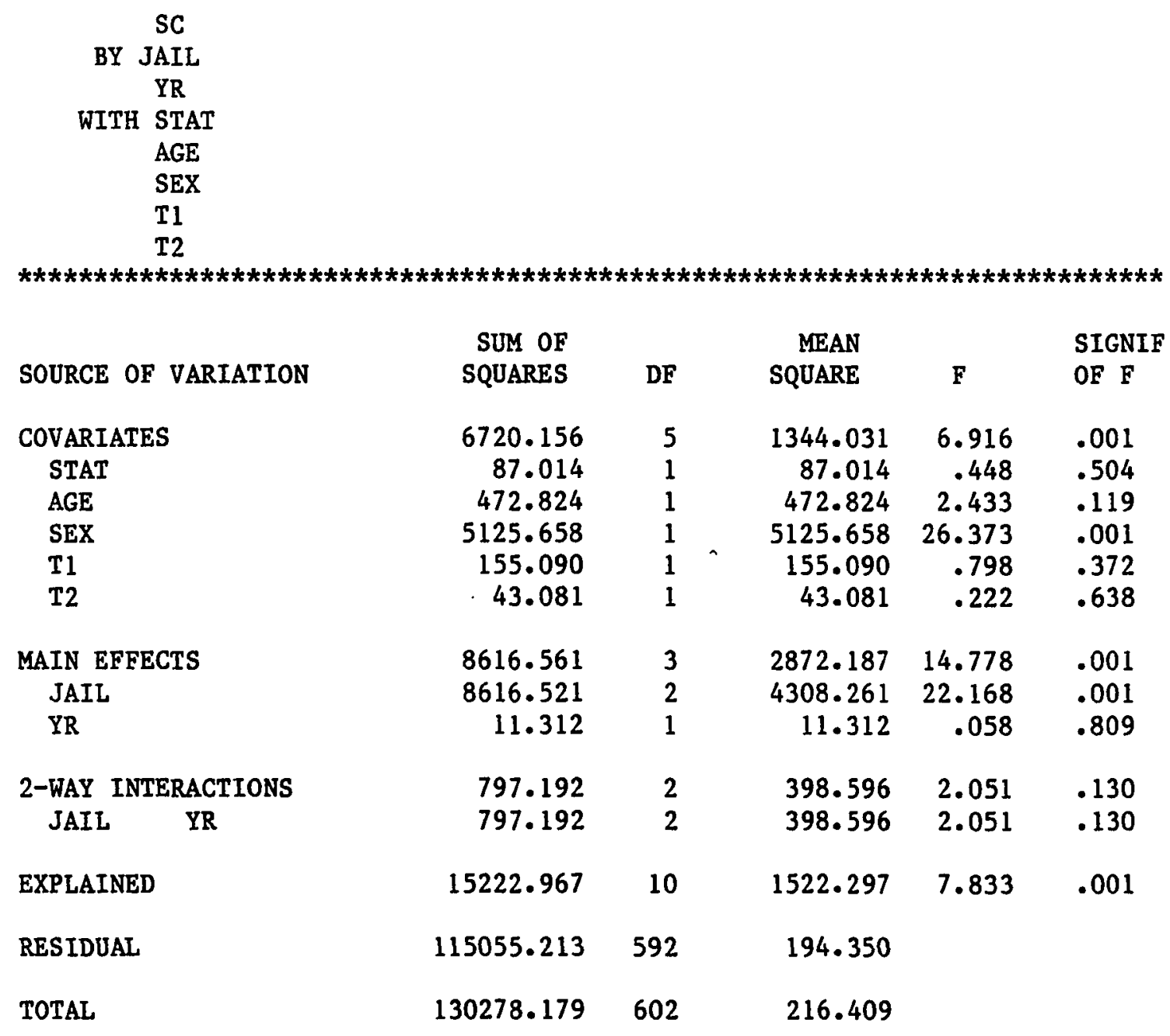


The subscale of Staff Control improved to the .001 level of significance for jail. Table XVI shows the degree of improvement and it appears that sex has the most to do with the increase in change on Staff Control. Women at the Claire Argo Center were used to a more informal atmosphere in contrast to the coolness and efficiency of the MCDC and Figure 12 reveals that overall, females at RBJ/MCDC did not score the MCDC as highly as did males in Staff Control. Figure 16 indicates that more staff at Salt Lake County Jall agreed that there was a positive social climate than inmates.

In the preceding examination of changes in overall scores on measures of jail social climate, we were able to determine with some accuracy whether the changes were due to the covarlates or a change in architecture. At this point, it would be useful to get a closer look at various groups within the study population and what the score changes, if any, were between 1983 and 1984.

The mean scores after analysis of covariance are shown below for members of the various age groups. Staff and inmate scores have been combined for a more global look at each jail. To have shown age mean scores for each age group by status would have overwhelmed the reader with a good many small, and mostly, insigificant numbers. Accordingly, the decision was made to combine staff and inmates by age groups. Comparison of age means with status on each subscale may be made by comparing Tables XVII-XXVI with Tables XXVI-XXVIII. To reiterate a caution advanced in Chapter IV, it should be kept in mind that some staff members appeared in both the 1983 and 1984 respondent groups. It seems reasonable to assume that these persons turned up proportionately 
in the age groups, that is, double counting of some staff had the effect of adding a constant to the age categories, thus not distorting the mean scores for age groups markedly. 
TABLE XVII

INVOLVEMENT

AGE MEAN SCORE AFTER ANALYSIS OF COVARIANCE FOR STAFF AND INMATES

Age $\quad 1983 \quad 1984$

$18-21$

$\begin{array}{lll}\text { RBJ } / \text { MCDC } & 42.82 & 36.73 \\ \text { SCJ } & 39.91 & 42.63 \\ \text { SLC } & 52.50 & 47.63\end{array}$

$22-25$

$\mathrm{RBJ} / \mathrm{MCDC}$

$\mathrm{SCJ}$

SLC

38.57

40.35

44.14

46.36

47.37

43.67

$26-30$

$\mathrm{RBJ} / \mathrm{MCDC}$

33.52

41.50

31.43

42.37

SCJ

42.93

43.95

$31-35$

$\mathrm{RBJ} / \mathrm{MCDC}$
$\mathrm{SCJ}$
$\mathrm{SLC}$

31.96

34.65

49.44

39.21

48.83

47.60

$36-44$

$\mathrm{RBJ} / \mathrm{MCDC}$

SCJ

29.83

40.21

41.68

48.12

43.20

SLC

45-55

$\mathrm{RBJ} / \mathrm{MCDC}$

37.17

30.86

49.80

SCJ

31.40

49.00

32.00

61.40

$56 \&$ 0lder

$\mathrm{RBJ} / \mathrm{MCDC}$

SCJ

46.50

0

14.00

54.00

0

70.00 
TABLE XVIII

SUPPORT

AGE MEAN SCORE AFTER ANALYSIS OF COVARIANCE FOR STAFF AND INMATES

$\begin{array}{ccc}\text { Age } & 1983 & 1984 \\ 18-21 & & \\ & & 38.59 \\ & 35.82 & 42.75 \\ & 31.36 & 37.50 \\ & 36.96 & \end{array}$

$22-25$

$\begin{array}{lll}\mathrm{RBJ} / \mathrm{MCDC} & 32.90 & 37.73 \\ \mathrm{SCJ} & 24.88 & 35.31 \\ \mathrm{SLC} & 39.64 & 36.83\end{array}$

$\mathrm{RBJ} / \mathrm{MCDC}$

$\mathrm{SCJ}$

SLC

$\mathrm{RBJ} / \mathrm{MCDC}$

SCJ

SLC

$\mathrm{RBJ} / \mathrm{MCDC}$

SCJ

SLC

RBJ/MCDC

SCJ

SLC

RBJ/MCDC

SCJ

SLC

$\mathrm{RBJ} / \mathrm{MCDC}$

SCJ

SLC
26-30

$\begin{array}{ll}29.78 & 36.18 \\ 25.07 & 35.95 \\ 34.66 & 35.81\end{array}$

31-35

31.16

31.71

39.67

40.50

37.33

39.70

$36-44$

$\begin{array}{ll}24.50 & 37.44 \\ 31.93 & 36.00 \\ 33.89 & 50.30\end{array}$

45-55

$\begin{array}{ll}35.67 & 44.40 \\ 21.86 & 41.40 \\ 22.00 & 56.00\end{array}$

$56 \&$ 01der

$\begin{array}{cc}64.00 & 24.00 \\ 0 & 0 \\ 0 & 0\end{array}$


TABLE XIX

EXPRESSIVENESS

AGE MEAN SCORE AFTER ANALYSIS OF COVARIANCE FOR STAFF AND INMATES

Age $\quad 1983 \quad 1984$

$18-21$

$\mathrm{RBJ} / \mathrm{MCDC}$

SCJ

SLC

$\mathrm{RBJ} / \mathrm{MCDC}$
$\mathrm{SCJ}$
$\mathrm{SLC}$

$\mathrm{RBJ} / \mathrm{MCDC}$

SCJ

SLC

$\mathrm{RBJ} / \mathrm{MCDC}$

SCJ

SLC

$\mathrm{RBJ} / \mathrm{MCDC}$

SCJ

SLC

RBJ/MCDC

SCJ

SLC

RBJ/MCDC

SCJ

SLC

$\begin{array}{ll}53.61 & 46.95 \\ 46.82 & 63.62 \\ 51.54 & 47.63\end{array}$

$22-25$

43.67

47.24

51.04

50.36

55.13

44.28

26-30

41.74

45.07

40.59

45.04

48.00

43.62

$31-35$

42.52

42.35

43.44

43.58

59.50

42.70

$36-44$

43.22

46.79

38.84

38.92

54.30

44.70

45-55

$$
\begin{aligned}
& 52.00 \\
& 45.71
\end{aligned}
$$

39.20

61.00

60.00

46.20

$56 \& 01 \mathrm{der}$

$$
\begin{gathered}
69.50 \\
0 \\
57.00
\end{gathered}
$$

26.00

0

43.50 
TABLE XX

AUTONOMY

AGE MEAN SCORE AFTER ANALYSIS OF COVARIANCE FOR STAFF AND INMATES

Age $\quad 1983 \quad 1984$

$18-21$

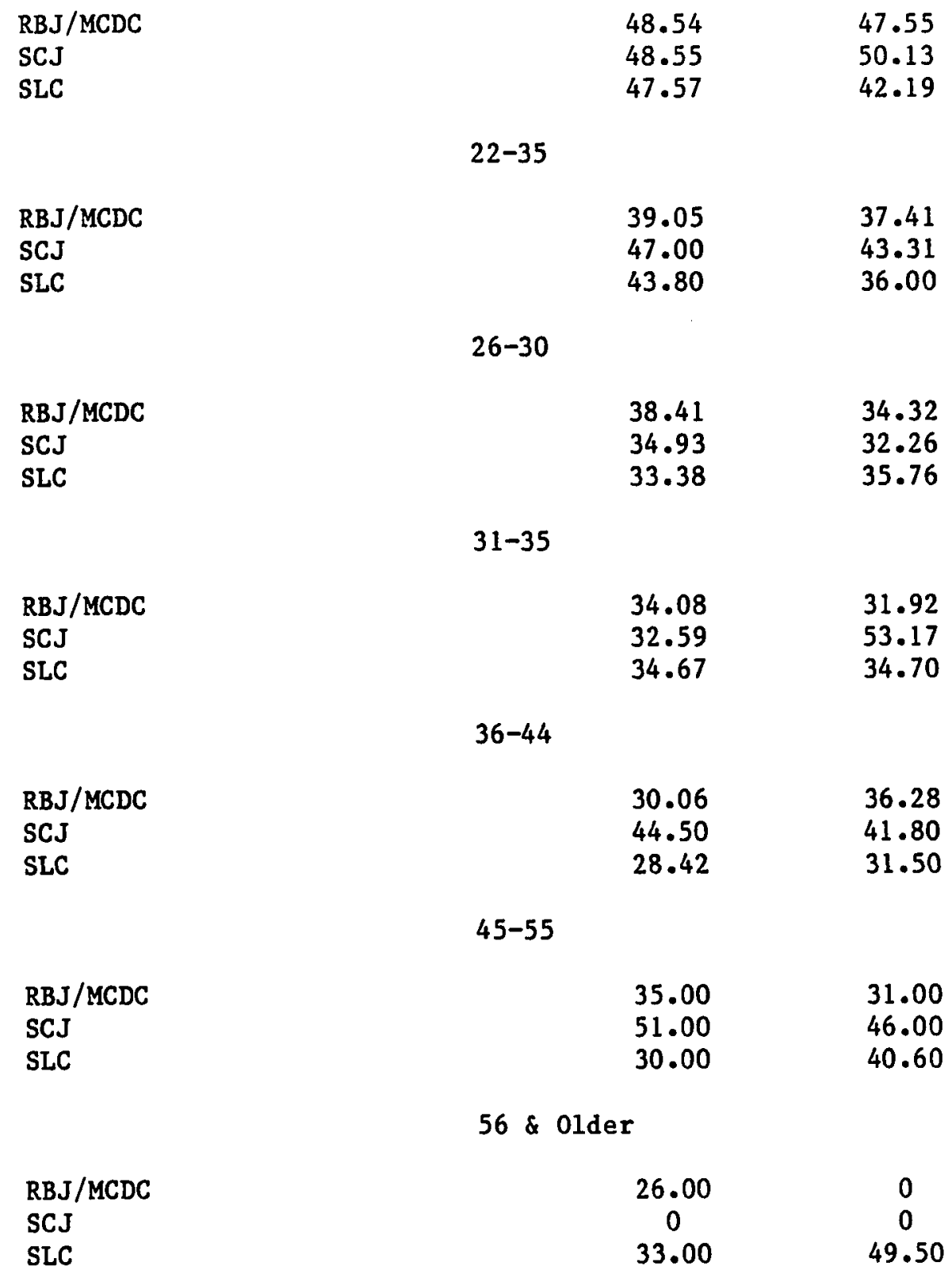


TABLE XXI

PRACTICAL ORIENTATION

AGE MEAN SCORE AFTER ANALYSIS OF COVARIANCE FOR STAFF AND IMMATES

$\begin{array}{ccc}\text { Age } & 1983 & 1984 \\ 18-21 & & \end{array}$

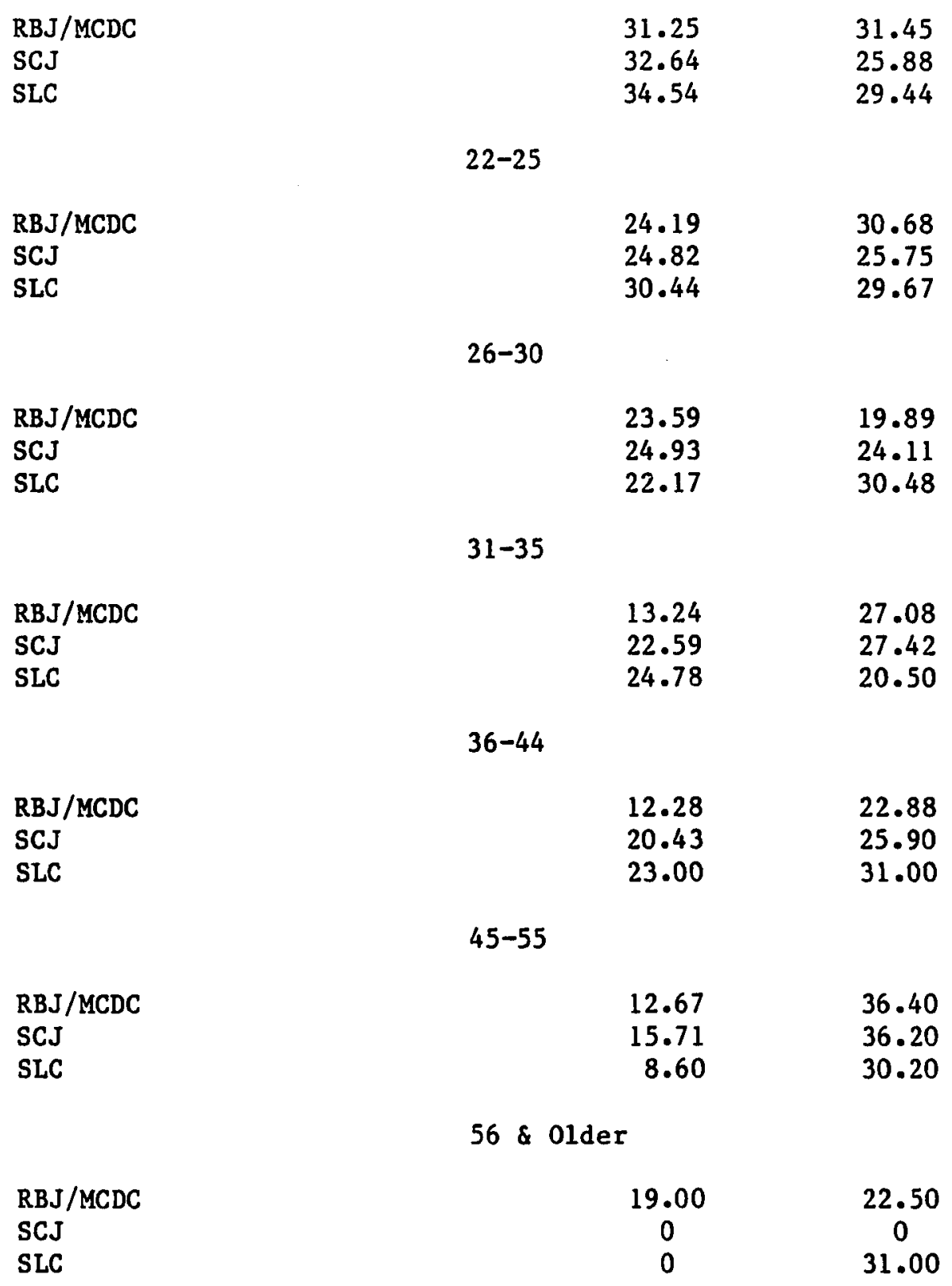


TABLE XXII

PERSONAL PROBLEM ORIENTATION

AGE MEAN SCORE AFTER ANALYSIS OF COVARIANCE FOR STAFF AND INMATES

$\begin{array}{ll}\text { Age } & 1983 \\ 18-21 & \end{array}$

$\begin{array}{lll}\mathrm{RBJ} / \mathrm{MCDC} & 42.68 & 37.50 \\ \mathrm{SCJ} & 36.82 & 42.63 \\ \mathrm{SLC} & 42.50 & 42.19\end{array}$

$22-25$

$\mathrm{RBJ} / \mathrm{MCDC}$

SCJ

43.05

43.53

41.73

SLC

44.84

43.38

33.83

$26-30$

$\mathrm{RBJ} / \mathrm{MCDC}$

SCJ

SLC

$\mathrm{RBJ} / \mathrm{MCDC}$

SCJ

SLC

$\mathrm{RBJ} / \mathrm{MCDC}$

SCJ

SLC

RBJ/MCDC
SCJ
SLC

RBJ/MCDC
SCJ
SLC

$\begin{array}{ll}40.04 & 39.68 \\ 43.21 & 39.95 \\ 36.24 & 42.95\end{array}$

31-35

$\begin{array}{ll}37.32 & 38.62 \\ 35.76 & 44.67 \\ 38.78 & 42.76\end{array}$

$36-44$

$\begin{array}{ll}41.11 & 38.08 \\ 42.21 & 45.50 \\ 43.79 & 46.30\end{array}$

45-55

$\begin{array}{ll}47.00 & 55.20 \\ 42.86 & 43.40 \\ 40.40 & 45.80\end{array}$

$56 \&$ older

$\begin{array}{cc}58.50 & 41.00 \\ 0 & 0 \\ 31.00 & 33.00\end{array}$


TABLE XXIII

ORDER AND ORGANIZATION

AGE MEAN SCORE AFTER ANALYSIS OF COVARIANCE FOR STAFF AND INMATES

$\begin{array}{lll}\text { Age } & 1983 & 1984 \\ 18-21 & \end{array}$

$\begin{array}{lll}\text { RBJ } / M C D C & 42.25 & 50.00 \\ \text { SCJ } & 35.45 & 34.87 \\ \text { SLC } & 51.43 & 45.81\end{array}$

$22-25$

$\mathrm{RBJ} / \mathrm{MCDC}$

$\mathrm{SCJ}$

39.14

31.47

48.84

57.36

39.44

SLC

26-30

RBJ/MCDC

SCJ

SLC

$\mathrm{RBJ} / \mathrm{MCDC}$

SCJ

SLC

RBJ/MCDC

SCJ

SLC

RBJ/MCDC

SCJ

SLC

$\mathrm{RBJ} / \mathrm{MCDC}$

SCJ

SLC
30.37

29.71

49.31

$31-35$

26.64

31.12

51.22

$36-44$

23.39

34.93

43.05

58.00

45-55

31.33

29.86

27.40

62.20

40.00

74.40

$56 \&$ 01der
56.92

32.10

33.11

51.24

59.92

26.00

40.00

$\begin{array}{cc}37.00 & 61.50 \\ 0 & 0 \\ 9.00 & 38.50\end{array}$


TABLE XXIV

CLARITY

AGE MEAN SCORE AFTER ANALYSIS OF COVARIANCE FOR STAFF AND INMATES

Age $\quad 1983 \quad 1984$

$18-21$

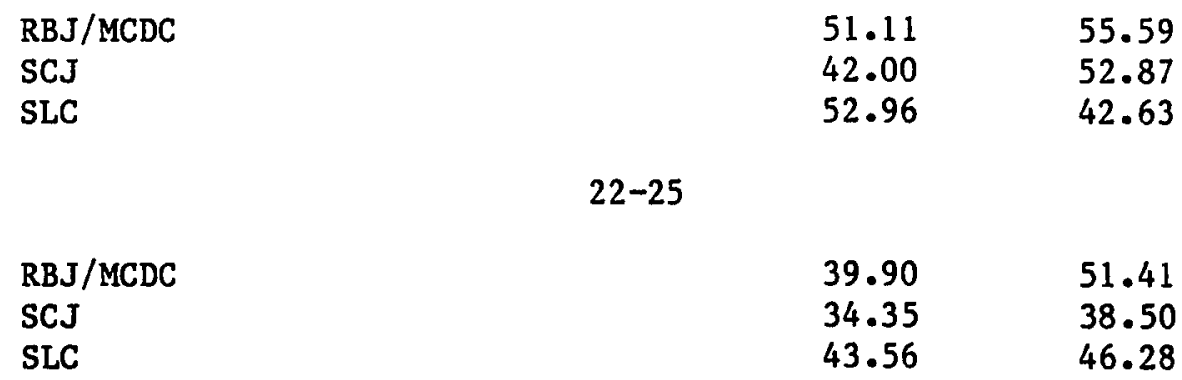

$26-30$

$\mathrm{RBJ} / \mathrm{MCDC}$

SCJ

SLC

$\mathrm{RBJ} / \mathrm{MCDC}$

SCJ

SLC

$\mathrm{RBJ} / \mathrm{MCDC}$

SCJ

SLC

$\mathrm{RBJ} / \mathrm{MCDC}$

SCJ

SLC

$\mathrm{RBJ} / \mathrm{MCDC}$

SCJ

SLC
38.07

35.67

51.59

47.64

45.37

43.95

$31-35$

32.24

32.06

42.78

53.62

40.83

46.10

$36-44$

29.94

40.00

36.84

51.04

40.40

51.10

45-55

36.50

19.43

33.20

55.80

42.40

59.60

$56 \&$ 01der

$\begin{array}{cc}37.00 & 43.00 \\ 0 & 0 \\ 0 & 0\end{array}$


TABLE XXV

STAFF CONTROL

AGE MEAN SCORE AFTER ANALYSIS OF COVARIANCE FOR STAFF AND INMATES

Age $\quad 1983$

$18-21$

$\begin{array}{lll}\text { RBJ } / M C D C & 47.79 & 51.86 \\ \text { SCJ } & 39.55 & 38.50 \\ \text { SLC } & 47.36 & 47.00\end{array}$

$22-25$

$\mathrm{RBJ} / \mathrm{MCDC}$

$49.29 \quad 52.82$

$48.00 \quad 38.25$

SCJ

SLC

49.32

53.50

$26-30$

$\mathrm{RBJ} / \mathrm{MCDC}$

SCJ

51.26

53.43

46.07

45.89

SLC

49.55

53.19

31-35

RBJ $/ M C D C$
SCJ
SLC

RBJ/MCDC

SCJ

SLC

RBJ/MCDC

SCJ

SLC

$\mathrm{RBJ} / \mathrm{MCDC}$

SCJ

SLC
55.68

51.06

50.89

$36-44$

54.44

43.00

49.89

45-55

58.33

45.71

45.80

46.00

33.20

37.40

$56 \&$ Older

$\begin{array}{cc}53.00 & 58.50 \\ 0 & 0 \\ 70.00 & 27.00\end{array}$


TABLE XXVI

RELATIONSHIP DIMENSION STATUS BY YEAR

Inmate Staff

$\begin{array}{llll}1983 & 1984 & 1983 & 1984\end{array}$

Involvement

$\begin{array}{lllll}\mathrm{RBJ} / \mathrm{MCDC} & 38.53 & 40.62 & 29.92 & 50.58 \\ \text { SCJ } & 39.89 & 44.84 & 27.29 & 41.07 \\ \text { SLC } & 48.22 & 48.10 & 30.89 & 37.60\end{array}$

Support

\begin{tabular}{lllll} 
RBJ & 33.15 & 34.48 & 29.21 & 53.50 \\
SCJ & 28.34 & 34.60 & 20.88 & 46.80 \\
SLC & 38.16 & 39.47 & 22.33 & 48.80 \\
& & \multicolumn{4}{c}{ Expressiveness } \\
& & \multicolumn{3}{c}{} \\
RBJ & 44.97 & 44.10 & 48.29 & 49.67 \\
SCJ & 43.89 & 55.18 & 49.42 & 55.00 \\
SLC & 46.96 & 44.71 & 37.56 & 44.80
\end{tabular}


TABLE XXVII

PROGRAM DIMENSION

STATUS BY YEAR

\begin{tabular}{lrrrr}
\multicolumn{4}{c}{ Inmate } & \multicolumn{2}{c}{ Staff } \\
& \multicolumn{4}{c}{ Autonomy } \\
& 1983 & 1984 & 1983 & 1984 \\
RBJ & 40.67 & 35.54 & 32.92 & 40.08 \\
SCJ & 39.66 & 41.93 & 47.29 & 45.80 \\
SLC & 39.03 & 37.56 & 33.61 & 29.20 \\
& & & & \\
& & Practical & Orientation \\
RBJ & 26.67 & 26.30 & & \\
SCJ & 25.84 & 24.93 & 19.21 & 26.58 \\
SLC & 29.50 & 28.18 & 10.17 & 40.60 \\
& & & & \\
& & Personal Problem 0 Orientation \\
RBJ & 42.25 & 38.03 & 39.26 & 47.33 \\
SCJ & 41.07 & 41.73 & 39.54 & 47.13 \\
SLC & 42.18 & 41.10 & 35.67 & 41.20
\end{tabular}


TABLE XXVIII

\section{SYSTEM MAINTENANCE DIMENSION STATUS BY YEAR}

\begin{tabular}{lcccc} 
& \multicolumn{3}{c}{ Inmate } & \multicolumn{2}{c}{ Staff } \\
& \multicolumn{4}{c}{ Order and Organization } \\
& 1983 & 1984 & 1983 & 1984 \\
RBJ & 38.64 & 62.13 & 19.34 & 56.08 \\
SCJ & 34.29 & 39.00 & 27.00 & 32.49 \\
SLC & 50.70 & 66.40 & 30.39 & 49.82 \\
& & & & \\
& & & Clarity & \\
RBJ & 42.99 & 54.92 & 29.18 & 50.94 \\
SCJ & 35.32 & 39.07 & 33.67 & 44.02 \\
SLC & 46.91 & 57.60 & 24.00 & 45.17 \\
& & & & \\
& & & Staff Control & \\
RBJ & 51.87 & 52.95 & 51.82 & 54.69 \\
SCJ & 44.29 & 37.80 & 50.25 & 43.29 \\
SLC & 48.15 & 60.80 & 54.56 & 49.55
\end{tabular}


Close inspection of the data reveals that after analysis of covariance, real improvement is noted in the Relationship dimension in two out of three subscales. The one exception was for inmate perception of Expressiveness. In regard to the Program Dimension, all three subscale scores improved for staff and inmate scores improved more modestly in MCDC compared to RBJ. The System Maintenance Dimension was the area that was believed to be the most radically improved after the move from RBJ to MCDC. This was especially true for the subscale of Order and Organization and for Clarity. Scores on the subscale of Staff Control improved only a modest amount.

\section{ANALYSIS OF DISCIPLINARY REPORTS \\ RBJ-1983/MCDC-1984}

Another way of analyzing life in a jail or correctional institution is to look at the numbers and kinds of disciplinary reports turned in during a period of time. The Incident Reports at both Rocky Butte jail and the Multnomah County Detention Center were reviewed for the periods of November 8, 1982 to November 7, 1983, the date RBJ was vacated. The Incident Reports for MCDC were reviewed for the period November 8, 1983 to November 1, 1984. Some surprising results were noted. For example, more incident reports were written for disruptive behavior in 1983-84 at the MCDC (332) than at RBJ (224) in 1982-83. Reports charging "failure to do as ordered" were about as frequent at RBJ as MCDC, "threatening staff", "attempted assault on staff", and "assault of staff" were also about as frequent at RBJ as MCDC. There were also a greater number of 
reports written for "fighting" and/or "assault on an inmate" written at RBJ than at MCDC during the study period. On the other hand, greater numbers of reports were written for "possession of contraband" and "destruction of property" at MCDC than at RBJ. Figure 26 depicts the disciplinary reports written during the last year of operation for RBJ and the first year of operation for MCDC.

What these numbers seem to indicate is that supervision was poor at RBJ; overcrowding masked deviant or destructive behavior and a goodly number of incidents went unreported by staff and inmates. First hand reports by former inmates of RBJ indicated that a good deal of unreported deviance unknown to staff went on there. On the other hand, reports by former inmates at the MCDC support the contention that it was a safe environment and that correctional officers were able to supervise inmates effectively and reported known incidents. Thus, one can only assume that a good deal of unreported skullduggery went on at RBJ, and the number of incident reports at $\mathrm{RBJ}$ gave a false reading of life in the tanks, while the number of incident reports at the MCDC were a more accurate depiction of life in the modules. Additionally, direct supervision of inmates, provided by having officers in the modules rather than being separated from the inmates, allowed the officers to recognize and deal with trouble before it escalated into a serious incident. 
INCIIJENIS RENUH'S

RBJ $11-8-82$ to $11-7-83$

MCDC 11-8-83 to $11-1-84$

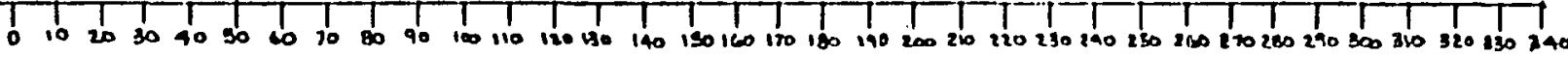

RBJ

MCDC Disobey Rules

$\mathrm{RBJ}$ Disrespectful/Abusive

MCDC Language

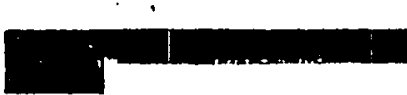

$\mathrm{RBJ}$

Disruptive

MCDC Behavior

\begin{tabular}{l} 
RBJ \\
\hline MCDC \\
as orlure to do
\end{tabular}

RBJ_Lreatened Staff

MCDC Attempted Assault

RBJ Theft

RBJ Fighting

MCDC Assault on Inmate

$\frac{\text { RBJ }}{M C D C}$ Contraband

RBJ

Destruction of

MCDC County Property
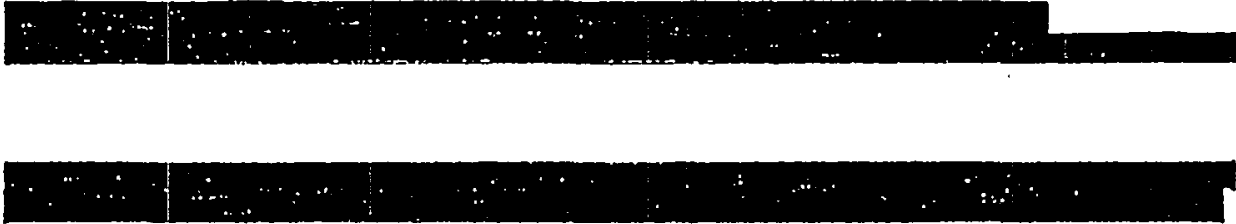

RBJ

$$
\text { Drugs }
$$

MCDC Possession/use
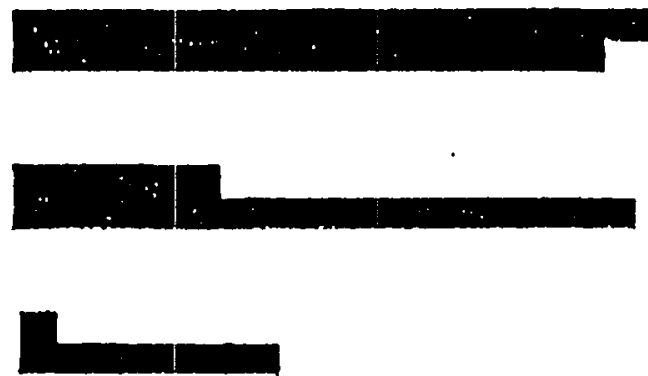

RB

Fighting

MCDC Assault on Inmate

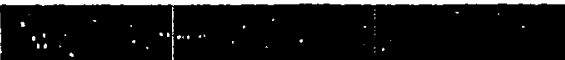

$\frac{\mathrm{RBJ}}{\mathrm{MCDC}}$ Contraband

RBJ Destruction of

County Property

$\frac{\text { RBJ }}{\text { MCDC }} \begin{gathered}\text { Drugs } \\ \text { Possesston/use }\end{gathered}$

RBJ GIving

MCDC False Statement

RBJ Menacing/Threating

MCDC Other Inmates

RBJ

Being in

MCDC Unathortzed Area

RBJ Escape/

MCDC Attempted Escape

RBJ Self Mutilation

MCDC Sulcide

RBJ Possession of

Weapon

RBJ

Disturbance 
- 


\begin{tabular}{|c|c|}
\hline$\frac{\mathrm{RBJ}}{\mathrm{MCDC}}$ & $\begin{array}{c}\text { Drugs } \\
\text { Possesston/use }\end{array}$ \\
\hline$\frac{\mathrm{RBJ}}{\mathrm{MCDC}}$ & $\begin{array}{l}\text { Giving } \\
\text { False Statement }\end{array}$ \\
\hline$\frac{\mathrm{RBJ}}{\mathrm{MCDC}}$ & $\begin{array}{l}\text { Menacing/Threating } \\
\text { Other Inmates }\end{array}$ \\
\hline$\frac{\mathrm{RBJ}}{\mathrm{MCDC}}$ & $\begin{array}{c}\text { Being In } \\
\text { Unathorfzed Area }\end{array}$ \\
\hline$\frac{\mathrm{RBJ}}{\mathrm{MCDC}}$ & $\begin{array}{c}\text { Escape/ } \\
\text { Attempted Escape }\end{array}$ \\
\hline$\frac{\mathrm{RBJ}}{\mathrm{MCDC}}$ & $\begin{array}{c}\text { Self Mutilation } \\
\text { Sulcide }\end{array}$ \\
\hline$\frac{\mathrm{RBJ}}{\mathrm{MCDC}}$ & $\begin{array}{c}\text { Possession of } \\
\text { Weapon }\end{array}$ \\
\hline$\frac{\mathrm{RBJ}}{\mathrm{MCDC}}$ & $\begin{array}{l}\text { Creating a } \\
\text { Disturbance }\end{array}$ \\
\hline$\frac{\mathrm{RBJ}}{\mathrm{MCDC}}$ & $\begin{array}{l}\text { Impersonating } \\
\text { Another Inmate }\end{array}$ \\
\hline$\frac{\mathrm{RBJ}}{\mathrm{MCDC}}$ & $\begin{array}{l}\text { Posiession of } \\
\text { stolen Property }\end{array}$ \\
\hline$\frac{\mathrm{RBJ}}{\mathrm{MCDC}}$ & Sexual \\
\hline$\frac{\mathrm{RBJ}}{\mathrm{MCDC}}$ & -Gambl1r \\
\hline
\end{tabular}





\section{DISCUSSION}

Within the last fifteen years, correctional authorities have spent much time and effort talking about the need for new prisons and jails. They have also elaborated convincing arguments in favor of more attractive and less threatening institutions rather than the old familiar bastille type of structure. Most persons intuitively believe that with the construction of new, modern facilities, more positive behavior on the part of inmates and staff will follow.

Nevertheless, 1ittle is known of the actual link between the environment and the keepers and the kept. It is assumed that "soft" architecture and "soft" surroundings will "uplift the spirit" and contribute to increased employee morale and help improve the character and moral fiber of the inmates. Further, some research seems to support this contention. Toch" has stated that "man is inextricably linked to his environment and that inextricability is a hard thing to study. We may try to separate man from his environment, and man does attempt to lead an independent existence, but a person feels and acts differently if he is transported from one setting to another." 5 This important notion has its roots in the symbolic interactionist arguments of George Herbert Mead. ${ }^{6}$ Blumer $^{7}$ captured the essentials of symbolic interactionism in three basic postulates: (1) Human beings act toward things on the basis of the meanings that things have for them, (2) the meaning of such things are derived from, or arise out of, the social interaction that one has with one's fellows, and (3) these meanings are handled in, and 
modified through, an interpretive process used by the person in dealing with the things he or she encounters. Symbolic interactionists reject the notion that people automatically and mechanically react to given stimuli. Instead, they believe that human beings creatively construct their actions in accordance with the meanings they attribute to various aspects of the environment. Meaning is not inherently in objects but derives from the uses people make of those objects.

A jail is an object. It symbolizes the power of the state to segregate and isolate persons from others who are defined as "good" and "honest." Garfinke ${ }^{8}$ has observed that the courts, and their extension in the form of jails and their staff, carry out a status degradation process that redefines the person and separates him or her from law abiding citizens. This "public denunciation" results in a good deal of damage to the self. If some mechanism is not found to preserve the self and deflect the results of the denunciation, one's self concept is likely to be fractured or irreparably distorted. On this point, Sykes asserted that this "deliberate, moral rejection of the criminal by the free community... results in a great threat to the self-concept of the prisoner and he must find some way to deal with that rejection and to find...a device for rejecting his rejectors." 9 In jail, when one is subjected to the loss of property, loss of social ties, and loss of ability "to take care of business" in addition to suffering the "pain" of rejection from undergoing a denunciation ceremony, and then is placed in a harsh, hostile and architecturally unfiendly environment, that person tends to search for a way to keep his or her self concept relatively intact. One method is to reject every symbol of the 
authority and power of the administration. This rejection of the rejectors is necessary but even more difficult because the prisoner must accept the food, clothing, blankets and all other symbols of his or her dependence on the administration if he or she is to survive physical$1 y \cdot 10$ As a consequence, any study of social climate is made more difficult by the prisoners' attempt to preserve a positive self concept. Nevertheless, Moos has made the best attempt thus far to measure social climate in that he accepted the inextricability of self, architecture, and subjective environment. It is the "organizational personality" that he attempted to measure through the CIES. This instrument measures the social climate in terms of three dimiensions: Interpersonal Relationships, Programs, and System Maintenance.

\section{INTERPERSONAL RELATIONSHIPS}

Living and working in jail is not easy. Irwin ${ }^{11}$ noted the disorientation that occurs after arrest and booking and claimed that it occurs roughly along three dimensions: loss of property, loss of social ties, and loss of ability to "take care of business." Alienation is also a problem and according to Irwin, alienation with its aspects of "powe rlessness, meaninglessness, normlessness, isolation, and selfestrangement" 12 are especially debilitating in a jail setting. Lombardo has called our attention to the fact that prison guards, "perform their tasks...in an environment that they perceive as both chaotic and boring. Faced with the threat of danger, a sense of powerlessness and inconsistent communications, the guard is a classic example of an alienated worker."13 Webb and Morris"14 captured the flavor of the guard subculture at a maximum security prison. The strain and attitude of the 
guards was summed up by one statement from a guard: "Understanding that some thieving, conniving son-of-a-bitch behaves the way he does because he's black and his mother was a whore and he never knew his father and he had to steal to eat-understanding that-is important, but it don't alter the fact the son-of-a-bitch is still a son-of-a-bitch."15

The difficulty of living and working in jails and prisons forces the individual to adapt to the environment in one way or another. Irwin noted that most studies of how convicts adapt to prison show that they follow one of two styles:

(1) an individual style-withdrawal and/or isolation, and (2) a collective style--participation in a convict social system whichthrough its solidarity, regulation of activities, distribution of goods and prestige, and apparent opposition to the world of the administration $\overline{-} \overline{6}$ helps the individual withstand the 'pains of imprisonment'.

These same phenomena occur in jail; the loss of property, the loss of social ties, and the loss of the ability to "take care of business" force the prisoner to adapt to the environment. Irwin ${ }^{17}$ has called our attention to the crowded conditions in the jails he visited and noted that these conditions cause new "fish" to be wary. In addition, inmates are overcome with a sense of powerlessness and perceive that they must wait, in what they see as a hostile environment, with only a bunk as their relatively secure territory.

The jails that Irwin studied resembled $R B J$ and were quite unlike the new MCDC, thus, one might expect to see considerable difference between social climate in RBJ and MCDC. Even so, mean scores on the subscales of Involvement and Support both showed negligible improvement in the change from RBJ to MCDC. The Involvement subscale mean score 
changed only by one point from 40 in 1983 to 41 in 1984. The Support subscale score changed from 35 to 36 in 1983 to 1984. Finally, the Expressiveness subscale score dropped from 48 in 1983 to 46 in 1984. Clearly, these scores showed negligible changes from 1983 to 1984.

When an analysis of covariance was performed with the covariates of Status, Age, Sex, $T_{1}$, and $T_{2}$, the gains in Support and Expressiveness at MCDC over RBJ were found to be insignificant. The change in Expressiveness, on the other hand, was found significant at the .004 level at the Sonoma County Jail and a slight drop from RBJ to MCDC was observed. The only exception was the covariate of Age in the Expressiveness subscale.

The covariate $T_{1}$ indicated that first-time offenders and relatively unsophisticated offenders perceived greater support from staff and fellow inmates in the RBJ/MCDC and in the other two jails in 1984 when compared to 1983.

In the case of MCDC, it may be that the sense of powerlessness was reduced, to a certain degree, by the improved classification system and by the direct supervision of officers in the modules. At the time that the new Policies and Procedures were written, an even more dependable classification procedure was developed in order to efficiently and accurately separate the more predatory inmates from those who were weaker and more passive. Thus, with the prisoner placed in a module with others more like him or her, there was less probability of being victimized, and as a consequence, inmates perceived greater support from fellow 1nmates. In addition, the correctional officers were placed in the module with the prisoners and the latter had the option of returning to an individual cell for safety and comfort if they desired to do so. 
One final note with regard to the Subscale of Involvement is that individual cells also allowed the inmates to control the duration and intensity of involvement with fellow inmates. Thus, changes in preceptions of Involvement might be expected to be negligible because inmates had the freedom to withdraw or control social involvement.

The ability to control relationships also results in decreased stress. Baum and Valins ${ }^{18}$ have pointed out that there is decreased stress when there is decreased social contact. In a related study to the current one, Houston and Page ${ }^{19}$ found that when the blood pressure of Correctional officers was taken on their posts in the RBJ in 1983 and then followed up in the MCDC in 1984, blood pressure was found to have decreased and the decrease was significant at the .001 level, indicating a less stressful work environment.

\section{PROGRAMS}

Mattick and Aikman ${ }^{20}$ has noted that the jail serves as the central intake center for the entire criminal justice system and plays host to a variety of disguised health, welfare, and social problem cases. Some jail experts and jail administrators denigrate the value of social programs and belleve that there is no place for them in a jail. Roy Casey in the preface to his 1958 book, The Modern Jail ${ }^{21}$ stated that: "...the vast majority of county and city jails cannot develop and operate successfully, realistic rehabilitation projects for the type of prisoners found in them."22

Today, nearly thirty years later, Casey's view persists. Rehabilitation is not the purpose of jails, indeed rehabilitation as a philosophical ideal or as program policy is rarely recognized even in prisons 
today. However, there is a place for certain programs in jails, especially the larger ones. The citizens of Multnomah County and the inmates of the MCDC are fortunate in that there are programs of an educational, spiritual, and counseling nature available. In addition, the largest and best stocked jail library in the United States is located on the 10 th floor of the MCDC and is made possible by the commitment of the Multnomah County Library Commission and the Interest of the owner of Powell's Book Store.

Programs also take other forms, as recognized by people who work in prisons and jails. Medical care is of the utmost importance and the courts have not been hesitant to intervene in this area. The MCDC has a fully accredited health program that is second to none. It is capable of handling any problem in modern, sterile conditions with the use of up-to-date equipment. The MCDC also an aggressive spiritual program. A full time ordained minister is a part of the staff and she supervises a complement of ordained and lay workers who volunteer their time for Christian work and counseling. Equal effort is also given to other religlous needs such as having a Rabbi as well as a Muslim Minister on call.

The need for counseling is not ignored either. There are four full time counselors on staff who are responsible for the case management needs of the inmates as well as one-to-one counseling. Narcotics Anonymous as well as Achoholics Anonymous offer one-on-one counseling on a regular basis. Finally, there is an outstanding jall education program. The inmates have the opportunity to progress through Adult Basic Education and through the GED if they wish. Additionally, pro- 
grammed books are available that acquaint the student with various vocational opportunities. Clearly, the MCDC has ample programs available for those inmates who wish to participate.

The inmates of the MCDC apparently did not view the availability of programs in a way that contributes to a more positive social climate. On the subscale of Autonomy, the score decreased from 42 in 1983 at the RBJ to 36 in 1984 at the MCDC. The subscale Personal Problem Orientation score remained at 27 over the test period and the Practical Orientation subscale score decreased from 42 to 39 . When an analysis of covariance was performed, score differences for Autonomy, Practical Orientation, or Personal Problem Orientation were not significant. Age was significant at the .001 level for Autonomy and Practical Orientation, and Status was also significant at the .001 level for the subscale of Practical Orientation.

One explanation for the lack of significance is that the inmates do not believe the programs to be worthwhile or to be offered with their welfare in mind. One inmate at the MCDC complained that prisoners did not have free access to the library and that the correctional officers would often confiscate library books during routine shakedowns. Counselors were thought by some inmates to be unavailable and not interested in solving inmate problems. The staff, on the other hand, believed that the Inmates had greater access to counseling and educational programs at MCDC than at RBJ.

SYSTEM MAINTENANCE

Over thirty years ago, Roy Casey $^{23}$ recognized the need for written policies to guide the operation of jalls. In addition, most jail 
administration texts written since that time either imply the importance of written procedures by suggesting that the reader follow the cook-book approach to effective jail management, as presented by the author, or they state in no uncertain terms how important specific, clear, and well written policies and procedures are to the daily functions of a jail. The American Correctional Association dealt with this issue specifically in Standards for Local Adult Detention Facilities. ${ }^{23}$

The ACA standards were followed to the letter when the Policies and Procedures for the $\underline{M C D C}$ were written. This was a nine-month effort conducted by members of the Transition Team and included the input of many correctional officers and staff. After the opening of the MCDC, the Policies and Procedures were amended in order to adjust the written word to reality. It is the effort expended in the writing of policies and procedures that apparently had its most significant impact on the inmate's perceptions of social climate in the MCDC.

On the three scales in the System Maintenance dimension, Order and Organization scores improved from 39 in 1983 to 57 in 1984, the Clarity subscale scores increased from 44 to 50, and Staff Control scores went up from 50 to 53.

When analysis of Covariance was performed using the covariates of Status, Age, Sex, $T_{1}$, and $T_{2}$, all three subscale changes were found to be significant at the .001 level. Clearly, the inmates perceived a more rorderly, well managed jail that is safer and more predictable than the old Rocky Butte jail. As a consequence, their perception of the jall as viewed through the lens of Increased order and organization, clarity of rules and procedures, and staff control influenced their perception of 
the social climate. In their mind, even though they were confined and had been confinted with their rejection by the community, they apparently percelved some redeeming qualities to the MCDC.

With regard to the perceived improvement on the part of staff, most of the arguments on behalf of the the inmates held true for the staff. However, there was the added belief of staff that they perform a job that is held in low esteem by most members of the community (a form of rejection). A survey of occupations by the National Opinion Research Center $^{24}$ disclosed that participants rated guards as slightly more prestigious than social welfare aids or ushers in movie theaters, but less prestigious than crossing guards and bridge tenders. To put this in perspective, an M.D. scored 82 on the NORC prestige scale, while a guard scored 22. Therefore, the improvement in percelved social climate is even more significant because staff perceptions of improvement translate into a more satisfied work force, less stress, less abuse of sick leave and less turn-over in the work force.

\section{SUMMARY}

This study appears to be significant principally in that the assumption that there is a clear and indisputable link between architecture and perceptions of social climate is challenged by the results. There are indications, however, that the human factor is the most important variable in the jail enterprise. Human beings write policies and procedures and humans carry out those policles and procedures. The data clearly suggested the importance of the human factor, perhaps more than 
a link between architecture and social climate. Staff and correctional officers are still defined as "the man, hacks, pigs, and screws" who symbolize the prisoners' rejection and dependence, but it may well be that the attitude and professionalism of staff and correctional officers help inmates recognize the positiveness of the social climate. This is easier in a "new generation" jall where the direct supervision of inmates forces correctional officers to develop interpersonal skills that lead to an increased sense of professionalism. The other side of the coin is that the absence of brute force allows the inmates to act as normal human beings, thus further enhancing the benign atmosphere of the MCDC. Finally, even though fellow inmates are percelved as "rabble" or not to be trusted, isolation or psychological withdrawal is believed to be the best way, on the part of inmates, to deal with the presence of others who the prisoner senses are mirror images of himself or herself. 


\section{FOOTNOTES}

${ }^{1}$ Timothy J. Flanagan and Edmund F. McGarrell, eds., Sourcebook of Criminal Justice Statistics-1985, U.S. Department of Justice, Bureau of Justice statistics (Washington, D.C.: U.S. Government Printing Office, 1986), p. 412.

2 John Irwin, The Jail.

${ }^{3}$ Donald R. Cressey, ed. The Prison: Studies in Institutional Organization and Change (New York: Holt, Rinehart and Winston, Inc., 1961). pp. 1-12.

${ }^{4}$ Hans Toch. Living in Prison: The Ecology of Survival (New York: The Free Press, 1977).

${ }^{5}$ Hans Toch, Living in Prison. p. 2.

${ }^{6}$ George Herbert Mead. Mind, Self, and Society (Chicago: University of Chicago Press, 1934).

7 Herbert Blumer. Symbolic Interaction: Perspective and Method (Englewood Cliffs, N.J.: Prentice-Hall, Inc., 1969).

${ }^{8}$ Harold Garfinkel, "Conditions of Successful Degradation Ceremonies", The American Journal of Sociology 61 (March, 1956):

pp. 420-424.

${ }^{9}$ Gresham M. Sykes. Society of Captives (Princeton, N.J.: Princeton University Press, 1958). p. 65.

${ }^{10}$ Gresham M. Sykes, Society of Captives. pp. 67-70.

11 John Irwin, The Jail.

12 John Irwin, The Jai1. p. 64 .

13 Lucien X. Lombardo. Guards Imprisoned (New York: Elsevier/North Holland, Inc., 1981). p. 140 .

${ }^{14}$ S.L. Webb and David G. Morris. Prison Guards: The Culture and Perspective of An Occupational Group (USA: Coker Books, 1978).

${ }^{15}$ S. L. Webb and David G. Morris. Prison Guards. p. 48.

${ }^{16}$ John Irwin. The Felon (Englewood Cliffs, N.J.: Prentice-Hall, Inc., 1970).

17 John Irwin, The Jail. p. 67. 
${ }^{18}$ Andrew Baum and Stuart Valins. Architecture and Social Behavior: Psychological Studies of Social Density (Hillsdale: Lawrence Erlbaum Associates, Publishers, 1977).

19 James G. Houston and Katherine Page. Blood Pressure as an Indicator of Correctional officer Stress, Unpublished. 1986 .

${ }^{20}$ Hans W. Mattick and Alexander Aikman, "The Cloacal Region of American Corrections," The Annals of the American Academy of Political and Social Science 381 (January, 1969): pp. 109-118.

${ }^{21}$ Roy Casey. The Modern Jail: Design, Equipment, Operation (Reen, TX: Continental Press, 1958).

${ }^{22}$ Roy Casey, The Modern Jail. p. iii.

${ }^{23}$ American Correctional Association. Standards for Local Adult Detention Facilities (Washington, D.C.: 1985).

${ }^{24}$ Robert M. Hauser and David L. Featherman. The Process of Stratification (New York: Academic Press). p.328. 
Chapter VI

SUMMARY, IMPLICATIONS, AND RECOMMENDATIONS

This chapter presents a summary of this research, conclusions drawn from the findings of the study, implications of those findings, and recommendations for the future.

\section{SUMMARY}

The purpose of this study was to investigate the impact of architecture on jail staff and inmates' perception of social climate. More specifically, an attempt was made to measure inmate and staff perceptions of social climate in the old Rocky Butte Jall by administering Rudolf Moos's Correctional Institutions Environment Scale to these groups. After the new Multnomah County Detention Center had been open for one year, the CIES was administered to volunteering inmates and staff in an attempt to measure social climate in that facility. In addition to gathering data from willing participants at the RBJ/MCDC, the same instrument was administered to the staff and inmates at two control jails that did not physically change during the study period. The dependent variable in this study was architectural change in the jails.

This study is important for several reasons. First, it generated information concerning inmate and staff perceptions of social climate in two types of jails: an old outdated and run down jail and a new ultra- 
modern, direct supervision jail. Second, with many communities contemplating replacement of their jails, information has been obtained that further expands the options available to policy makers. Third, the information obtained from the study points the way for further research in jail design.

The research literature relating to this dissertation was reviewed in three areas; architecture, organizational social climate, and jalls and prisons. It has been noted that architects usually claim to be designing for people and interested in creating an environment that can "uplift the spirit and enhance the sense of well-being." 1 Some criticisms of this statement have been made ${ }^{2}$ and nowhere is this statement more refutable than the infamous Prultt-Igoe Housing Project in St. Louls, Missouri which was so "user-unfriendly" that it was ultimately razed. Prisons and jails usually are poorly designed as well. Many are nothing more than concrete boxes that are unsafe, outdated, and often dirty and poorly maintained.

Renato Tagiuri ${ }^{3}$ has provided a working definition of organizational climate. Organizational climate is an emerging concept which refers to a relatively enduring aspect of an organization in which many variables are in simultaneous operation and is experienced by organization members, influences their behavior, and can be described by a particular set of characteristics.

Examples of research on the organizational climate of jalls or impact of architecture on inmates and staff are few indeed, but the meaniningful work that has been done has been accomplished by Wener and Clark. In their investigation of the U.S. Bureau of Prisons Metropolitan 
Correctional Centers in New York and San Diego found that the bedrooms (cells) were the most heavily used areas of the institution. Because the opportunity to escape to a single cell was available, there was less perceived tension and discomfort in the MCC than in traditional institutions. In addition, inmates in single cell modules reported for sick call less often than did inmates in open dormitories. Another example of inmate perceived comfort was the lack of vandalism and grafiti. Wener and Clark concluded that when ownership of an area was assured, then the inhabitants cared for the area and protected it.

The following hypotheses was investigated in this study:

1) The combined perceptions by inmates of social climate will be higher or more positive in the new Jail (MCDC) than in the old one (RBJ) while no change in perception will be observed in the two control jails.

2) The combined perceptions by staff of social climate will be higher or more positive in the new Jail (MCDC) than in the old one (RBJ) while no change in perceptions will be observed in the two control jalls.

The samples for the study were drawn from the inmate population and staff of the Rocky Butte Jail, Portland, Oregon; Sonoma County Jall, Santa Rosa, California; Salt Lake County Jail, Salt Lake City, Utah; and the Multnomah County Detention Center, Portland, Oregon. These were samples of conventence in that questionnaires were given to all willing participants in each of the jails on the days selected for sampling. The 1983 total of respondents was 498, while in 1984 it was 379.

All data resulting from the administration of the CIES were analyzed using the SPSS. Analysis of covariance was used in order to eliminate "noise" and to allow determination of whether or not dif- 
ferences over time were attributable to architecture or the covariates. In analysis of covariance, multiple linear regression is performed on the independent variables (covariates). The residuals are then subjected to an analysis of variance (ANOVA) which allows the elimination of the influence of the covariates. The F score then allows conclusions to be drawn. The level of significance necessary for the rejection of the null hypothesis was set at the .005 level.

The results of data analysis are summarized below:

1. Nonsignificant $\underline{E}$ ratios were obtained for the subscales of Involvement (.209), Expression (.987), Autonomy (.274), Practical Orientation (.132), and Personal Problem Orientation (.315) in $\mathrm{RBJ} / \mathrm{MCDC}$ and no change in the same subscales for the control fails were obsezved.

2. Significant $F$ ratios were obtained for the subscales of Support (.004), Order and Organization (.001), Clarity (.001), and Staff Control (.001).

More generally, the following conclusions were reached:

1. Alteration in architecture had no overall impact on the perception of staff and inmates of social climate in the jalls studied even though there were significant $F$ ratios in the Systems Maintenance dimension and the subscale of Support. In addition, various subgroups percelved the social climate to be more positive than did other subgroups. 
2. The existence of complete, thorough and well written policies and procedures did affect staff and inmate perceptions of how well a jail is managed.

3. Due to the need for prisoners and staff to preserve their selfesteem, an entirely accurate assessment of social climate may never be possible.

\section{IMPLICATIONS \& RECOMMENDATIONS}

The results of this study indicate that the Multnomah County Detention Center was not perceived by inmates and staff as having as favorable a social climate as expected. While there is ample room for continued research in this area, this finding should begin to cause policy makers and architects to question some of their basic assumptions with regard to "soft" architecture.

According to a recent survey of our nation's jalls, 459 jails were built prior to 1920 and 600 were built between 1920 and 1950 . It is a falr assumption that many communities are now in the process of attempting to replace or renovate outdated jails. This need for replacement of old, outdated jails has not escaped the attention of contractors and builders, many of whom claim some expertise in the field of jail design and construction. However, elaborate and complicated designs and construction techniques may not be the answer to fail construction. One needs only to cite King County, Washington (Seattle) or Travis County, Texas (Austin) to learn the full story of incompetence, ignorance of user needs, confused commissioners and corruption. King County, Washington began construction of a new jail at about the 
same time construction of the MCDC began. The King County Jail opened approximately eighteen months after the MCDC opened and after lawsuits and countersuits had been filed over delays in the construction project. At least one sub-contractor filed for bankruptcy and little attention was paid to the transition process until shortly before the anticipated opening. Part of the blame can be laid at the doorstep of the County Commissioners who chose to allow a single company to construct the entire building. The MCDC on the other hand, was constructed using the Construction Manager concept. Under this plan, a company contracts to oversee jail construction and is responsible for developing the various trade packages. In this manner, if one sub-contractor falls behind, or goes bankrupt, the other areas of construction continue unaffected. The results are seen in the MCDC which opened on time and under budget.

Travis County, on the other hand, is another matter. The jail was constructed but the contractor cut so many corners that the State Fire Marshall declared the building unsafe for occupancy. After four years of vacancy and added expense, it was finally opened in 1986, a monument, it seems, to incompetance and corruption. It is small wonder that many countles that build a new jall do not get what they need. The National Institute of Justice and the National Institute of Corrections have attempted to fill a need for jail construction information by publishing papers on new construction techniques and concepts ${ }^{5}$ and the NIC's How to $\underline{\text { Plan a }}$ New Institution ${ }^{6}$ offers a cookbook approach to opening a new institution.

How to Plan a New Institution is an impressive-looking document that leads the planner through the philosophy of direct supervision 
jails, pre-architectural program, financing, staffing and fire safety among other topics. It is aimed at an unsophisticated audience and is a valuable guide to planning, but there is little documentation to acquaint the reader with the behavioral science and architectural foundations upon which direct supervision jails are based. The essence of these foundations are that positive social climate results from direct staff supervision, soft furnishings, and a non-linear manner of construction. Eight "principles and dynamics" for managing the Modular/Direct Supervision model are advanced that, in the NIC's opinion, if followed will consistently elicit a desired inmate response. Those principles are: ${ }^{7}$

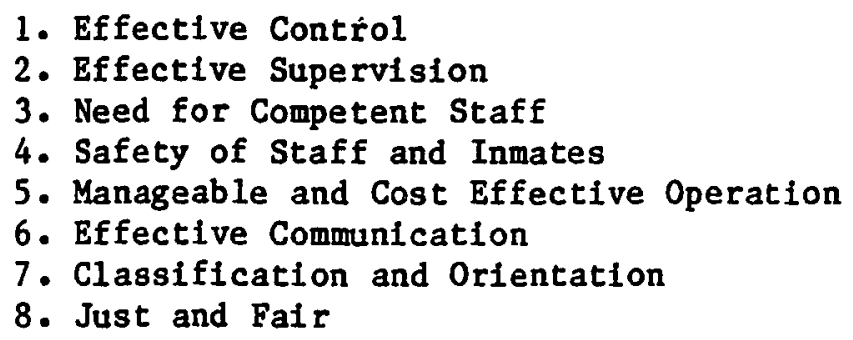

Obviously these principles shed little light on reasons for designing, or not designing, a "new generation jail". Judging from the findings of this study, the design of the jall is strictly a matter of whether or not the local authorfties choose to design a new generation jail or direct supervision jail, as it is called by the NIC. The findings of this study indicate that an older design may be just as effective in promoting a positive social climate if attention is paid to the development of sound and meaningful policies and procedures and if officers are not separated from the inmates by bars.

We would like to believe that every community would choose to 
construct a jail that is a contribution to the skyline and has a warm, inviting presence. That, however, is not the case and many local jurisdictions simply do not have the money to pay for the "frills" or choose not to pay the architect's fees that go hand in hand with such beautiful additions to the skyline. Instead, those communities need some assurance that they can improve their old jall by some other means than spending hundreds of thousands, if not millions of dollars for construction or renovation. This research suggests that if the policies and procedures are properly developed, then authorities may have an effective alternative to expensive construction projects and hence they may choose a design less elaborate than the MCDC and spend time on sound pollcies and procedures.

It is suggested that if a community is faced with the dilemma of an expensive construction project that it can ill afford or chooses to settle for something less but more affordable, then the four following questions should be answered before a new jail is undertaken:

1. Have the courts interceded in your jurisdiction and articulated guidelines in terms of population capacity and programs including recreation and medical attention?

Until recently the courts have been reluctant to interfere in the running of correctional institutions and fails. However, as violations of civil rights and the safety and well being of inmates more frequently came to the attention of the courts, reluctance faded and interest increased until they began to order changes and in some instances assigned a Spectal Master who was responsible for the carrying out of the court's orders. Any plans by a jurisdiction to build or renovate a 
jail must take into account orders of the court and make an effort to include those orders into the design plans of the jail.

2. What are the demands of the proposed site?

While nearly every county and many cities have a jail, often little consideration is given to an adequate place for the jail in the overall plan of the community. Multnomah County, Oregon successfully integrated its jail into the Central Business District of the City of Portland. This location is convenient to public transportation, the courts, and attorneys and the site 1 s adequate in size and all utilities were already in place.

Other communities are not so farsighted. Union County, New Jersey has chosen a site next to a high speed commuter rall line right of way and the plot 1tself is an irregular triangle shape that is extremely awkward for the designer. However, it is a site that is not desirable commerclally and has little value for tax purposes. Kalamazoo, Michigan, on the other hand, located a new jail outside of the city on surplus ground. It is inconvenient to public transportation, the courts, and for the attorneys, (much like the old Rocky Butte Jall) and the low swampy land has created problems. In summary, in neither instance did user needs come to the fore of the planner's thinking.

3. What are the desires of the local authorities?

On the surface this is a foolish question. Of course the planners want an adequate jail. But before letting out bids and allowing the architects to tell them what the city or county needs, the planners should sit down and reach agreement on where the jail should be; can they afford an elaborate high technology type jail; should it be 
attractive and non-threatening in appearance; and finally what type of programs will be offered. Once these issues are settle $\dot{i}$, then bids can be let and proposals solicited.

4. Do policies and procedures for operation of the jail currently exist and if not is there a plan to develop, publish and operate by policles and procedures that meet ACA accreditation standards?

As this research indicates, sound and effective policles and procedures apparently do more than anything else to establish the perception of a positive social climate. Thought should be given to policies and procedures before design of the jail is undertaken. One of the lessons learned by members of the Transition Team that opened the Multnomah County Detention Center is that if they had developed a rough set of Policies and Procedures before the jail was designed, some aspects of the jaij. architecture would be different. Let the Policies and Procedures drive the jail design and not the reverse.

Based on the results of this study, the following recommendations are offered for further research:

1. Research should be conducted to further probe the impact of architecture on social climate perceptions of inmates and staff.

2. Research should be conducted on the affect of well written and articulated policies and procedures on the management of a jail. The results of this line of inquiry are greatly needed to substantiate or refute commonly held assumptions of practitioners. It would be especially informative to study the effect of well-written policles and procedures in an old, outdated jail vs. poorly-written policies and proce- 
dures in a new modern jail.

3. Further research is suggested by comments of inmates in the MCDC that it is too sterile and cold. What effect, for example, does the use of passive surveillance techniques have on alienation of inmates?

4. Research is needed to determine whether or not the general public's perceptions of jails change when the jail is of modern design and is congruent with 1 ts surroundings. The MCDC is a handsome addition to the Central Business District and conveys majesty yet is inviting to the public. Its restaurants and shops on the street level communicate a sense of participation by the community. What effect if any does this have on the average citizen's idea of the people who are kept on 1 ts detention floors?

One final recommendation is offered not related to research. An inquiry should be made into the possibility of Functional Unit Management in the MCDC. Currently the jail is managed along traditional lines and some thought should be given to the implementation of Functional Unit Management in order to increase a sense of participation by the corrections officers and to further decrease inmate alienation and overcome a sense of being ignored by staff. 
FOOTNOTES

${ }^{1}$ Kenneth H. Craik, "Environmental Psychology," in New Directions in Psychology No. 4 (New York: Holt Rinehart and Winston, 1970).

2 Allen Lange, Charles Burnette, Roland McLasky, David Vashon, eds. Designing for Human Behavior: Architecture and the Behavioral Sciences, (Stoudsburg, PA.: Dowden, Hutchinson, and Ross, Inc., 1974).

${ }^{3}$ Renato Tagiuri, Organizational C1imate: Exploration of a New Concept.

${ }^{4}$ National Sheriff's Association. The State of Our Nations Jails 1982 (Washington, D.C.: National Sheriff's Association, 1982). p. 79.

${ }^{5}$ National Institute of Justice, "California Tests New Construction Concepts," Construction Bulletin, (Washington, D.C.: National Institute of Justice, 1986).

${ }^{6}$ National Institute of Corrections, How to Open a New Institution, Resource Guide, and Planning of New Institutions, Phase II, (Boulder, C0: National Institute of Corrections, 1983).

${ }^{7}$ National Institute of Corrections, How to Open a New Institution, Resource Guide, and Planning of New Institutions, Phase II. 
LITERATURE CITED 


\section{Literature Cited}

Advisory Commission on Intergovernmental Affairs. Jails: Intergovernmental Dimensions of a Local Problem. Washington, D.C.: 1984 .

American Correctional Association. Standards for Local Adult Detention Facilities. Washington, D.C.: 1985 .

Baum, Andrew and Stuart Valins. Architecture and Social Behavior: Psychological Studies of Social Density. Hillsdale, PA: Lawrence Earlbaum Assoclates, Publishers, 1977.

Bickman, Leonard, Alan Teger, Thomasina Gabriel, Carl McLaughlin, Mark Beger, and Earl Sunaday. "Dormatory Density and Helping Behavior," Environment and Behavior 5, No. 4. December, 1973. 465-490.

Blumer, Herbert. Symbolic Interactions: Perspective and Method. Englewood Cliffs: Prentice-Hall, Inc., 1969.

Casey, Roy. The Modern Jail: Design, Equipment, Operation. Reene, TX: Continential Press, 1958.

Casey, Roy. "Catchall Jails," The Annals of the American Academy of Political and Social Sciences. 293 May, 1954. 28-34.

Corbett, Judith A. "Are Sultes the Answer?" Environment and Behavior, 5, No. 4. December, 1973. 421-434.

Craik, Renneth H. "Environmental Psychology," in New Directions in Psychology, No. 4. New York: Holt, Rinehart and Winston, 1970.

Cressey, Donald R. ed. The Prison: Studies in Institutional Organization and Change. New York: Holt, Rinehart and Winston, Inc., 1961.

Cressey, Donald R. "Limitations on Organization of Treatment in the Modern Prison," in Social Sclence Research Counc1l. eds. Theoretical Studies in Social Organization of the Prison. New York: Social Science Research Council, 1960.

Cressey, Donald R. and John Irwin. "Thieves, Convicts, and the Inmate Culture," Social Problems, 10, No. 2. Fall, 1962.

Darrow, Clarence. Crime: Its Cause and Treatment. 1922. Montclair, New York: Patterson Smith, 1972. 
Davis, Alan J. "Sexual Assaults in the Philadelphia Prison System and Sheriff's Vans," in Clifton D. Bryan, ed. Sexual Deviancy in Social Context. New York: New Viewpoints, 1977.

Eoyang, Carson K. "Effects of Group Size and Privacy in Residential Crowding," Journal of Personality and Social Psychology. 30, No. 3. September, 1974. 389-392.

Fishman, Joseph. Crucibles of Crime. New York: Cosmopolis Press, 1923.

Garafalo, James and Richard 0. Clark. "The Inmate Subculture in Jails," Criminal Justice and Behavior. 12, No. 4. December, 1985.

Garfinkel, Harold. "Conditions of Successful Degradation Ceremonies," The American Journal of Sociology. 61 March, 1956. 420-424.

Glaser, Daniel. "Some Notes on Urban Jails," in Daniel Glaser. ed. Crime In the City. New York: Harper and Row, 1970.

Goffman, Erving. "On the Characteristics of Total Institutions: The Inmate World," in Donald R. Cressey, ed. The Prison: Studies in Institutional Organization and Change. New York: Holt, Rinehart and Winston, Inc., 1961.

Goldfarb, Ronald. Jails: The Ultimate Ghetto. Garden City, N.Y.: Anchor Press/Doubleday, 1975.

Grosser, George H. "External Setting and Internal Relations of the Prison," in Theoretical Studies in Social Organization of the Prison by Richard A. Cloward, Donald R. Cressey, George H. Grosser, Richard McCleery, Lloyd E. Ohlin, Gresham M. Syskes, and Sheldon L. Messinger (New York: Social Science Research Council, 1960). pp. 5-27

Gusten, R. Noise in Ja11s: The Constitutional Issues. Washington, D.C.: National Clearing House for Criminal Justice Planning and Architecture, 1977.

Guy, E., J. Platt, I. Zwerling, and S. Bullock. "Mental Health Status of Prisoners in an Urban Jail," Criminal Justice and Behavior. 12, No. 1 March, 1985. 29-53.

Hauser, Robert M. and David L. Featherman. The Process of Stratification. New York: Academic Press, 1977.

Hayes, Lindsay M. "and Darkness Closes in... a National Study of Jall Suicides," Criminal Justice and Behavior. 10, No. 4. December, 1983. $461-484$.

Hibbert, Christopher. The Roots of Evil. Boston: Little Brown and Company, 1963. 
Houston, James G. and Katherine Page, Blood Pressure as an Indicator of Correctional officer Stress, Unpublished, 1986.

Irwin, John. The Felon. Englewood Cliffs: Prentice-Hall, Inc., 1970.

Irwin, John. The Jail: Managing the Underclass in American Society. Berkeley: University of California Press, 1985.

Jacobs, James. Stateville: The Penitentiary in Mass Society. Chicago: University of Chicago Press, 1977. .

James, Lawrence P. and Allen P. Jones. "Organizational Structure: A Review of Structural Dimensions and Their Conceptual Relationships with Individual Attitudes and Behavior," Organizational Behavior and Human Performance. 16, No. 1. June, 1979. 74-113.

Jones, Allen P. and Lawrence R.James. "Psychological Climate: Dimensions and Relationships of Individual and Aggregated Work Environment Perceptions," Organizational Behavior and Human Performance. 23, No. 2. April, 1979. 201-250.

Lange, Allen, Charles Burnette, Roland McLaskey, David Vashon. ed. Designing for Human Behavior: Architecture and the Behavioral Sclences. Stroudsburg: Dowden, Hutchinson, and Ross, Inc., 1974.

Levinson, Robert B. and Roy E. Gerard. "Functional Units: A Different Correctional Approach," Federal Probation, 30, No. 4. December, 1973. 12-16.

Lincoln, James R. and Gerald Zeitz. "Organizational Properties from Aggregated Data: Separating Individual and Structural Effects," American Sociological Review. 45, No. 3. June, 1980. 391-400.

Lombardo, Lucien X. Guards Imprisoned New York: Elsevier/North Holland, Inc., 1981 .

Mattick, Hans W. "The Contemporary Jails of the United States: An Unknown and Neglected Area of Justice," in Daniel Glaser, ed. Handbook of Criminology. Chicago: Rand McNally, Publishiing Company, $1 \overline{974}$.

Mattick, Hans $W$. and Alexander Aikman. "The Cloacal Region of American Corrections," The Annals of the American Academy of Political and Social Sciences. 381. January, 1969. 109-118.

McCleery, Richard. "Communication Patterns as Bases of Power," in Theoretical Studies in Social Organization of the Prison by Richard A. Cloward, Donald R. Cressey, George H. Grosser, Richard McCleery, Lloyd E. Ohlin, Gresham M. Sykes, and Sheldon L. Messinger. (New York: Social Science Research Counci1, 1960). 
Mead, George Herbert. Mind, Self, and Society, Chicago: University of Chicago Press, 1934.

Moore, Winston E. "Lowdown on High Rise Jails," Parks and Recreation, September, 1974. 29-33.

Moos, Rudolf. Evaluating Correctional and Community Settings. New York: John Wiley and Sons, 1975.

Moos, Rudo1f. Correctional Institution Environment Scale, Manual. Palo Alto: Consulting Psychologists Press, Inc., 1974.

National Institute of Justice. "California Tests New Construction Concepts," Construction Bulletin. Washington, D.C.: National Institute of Justice, 1986.

National Institute of Corrections. How to Open a New Institution, Resource Guide. Boulder, CO: National Institute of Corrections, 1983.

National Sheriff's Association. The State of Our Nation's Jails - 1982. Washington, D.C.: 1982 .

Paulus, P., V. Cox, G. McCain, and H. Chandler. "Some Effects of Crowding in a Prison Environment," Journal of Applied Social Psychology. 5, No. 1 January, 1975. 86-91.

Pomeranz, David. "Environmental Psychology," in Leonard Krasner. ed. Environmental Design. New York: Pergaman Press, 1980.

Prohansky, Harold M., William H. Ittleson, and Leanne G. Rivlin. Environmental Psychology, 2nd ed., eds., New York: Holt, Rinehart and Winston, 1976 .

Pugh, Ralph B. "Imprisonment in Medieval England," Cambridge: University Press, 1968, in John Irwin. The Jail. Berkeley: University of California Press, 1985.

Salgert, Susan. "Stress-Inducing and Reducing Qualities of Environment," Environmental Psychology in Harold M. Prohansky, William H. Ittleson, and Leanne G. Rivlen ed. Environmental Psychology, 2nd ed. New York: Holt, Rinehart and Winston, 1976.

Schneider, Benjamin. "Organizational Climates: An Essay," Personnel Psychology. 28, No. 1. March, 1975. 447-479.

Schnelder, Benjamin, John J. Parkington, and Virginia M. Burton. "Employee and Customer Perception of Service in Banks," Administrative Science Quarterly. 25, No. 2. June, 1980. 252-267. 
Se10, Elaine. Review of Evaluating Correctlonal and Community Settings, by Rudolf H. Moos, in Journal of Criminal Justice. 4 , No. 4. December, 1976. 348-350.

Smith, Dale E. "Local Corrections: A Profile of Inmate Concerns," Criminal Justice and Behavior. 11, No. 1. March, 1984. 75-99.

Smith, W. Alan and C.E. Fenton. "Unit Management in a Penitentiary: A Practical Experience," Unpublished paper presented to the American Correctional Assocation Congress, Milwaukee, Wisconsin, 1973.

Stein, Jess, Editor-in-Chief. Random House Dictionary of the English Language. Random House, 1971.

Stokels, Daniel. "On the Destinctions Between Density and Crowding: Implications for Future Research," Psychological Review. 79, No. 3. May, 1972. 275-277.

Street, David. "The Inmate Group in Custodial and Treatment Settings," American Sociological Review. 30, No. 1. February, 1965. 40-55.

Street, David, Robert D. Vinter, and Charles Perrow. Organization for Treatment. New York: The Free Press, 1966.

Sykes, Greshem M. Society of Captives. Princeton: Princeton University Press, 1958.

Sykes, Greshem M. "Men, Merchants, and Toughs," Social Problems. 4, No. 2. October, 1956. 130-137.

Sykes, Greshem M. and Sheldon L. Messinger. "The Inmate Social System," in Theoretical Studies in Soclal Organization of the Prison by Richard A. Cloward, Donald R. Cressey, George H. Grosser, Richard McCleery, Lloyd E. Ohlin, Gresham M. Sykes, and Sheldon L. Messinger. (New York: Soclal Sclence Research Counc11, 1960). pp. 5-19.

Tagiuri, Renato. Organizational Climate: Explorations of a New Concept. Cambridge: Harvard University Press, 1968.

Toch, Hans. Living in Prison: The Ecology of Survival. New York: The Free Press, 1977 .

U.S. District Court, Jordan, et al. V. Multnomah County, et al., CIV. 80-841 RE.

Valins, Stuart and Andrew Baum. "Residential Group Size, Social Interactions, and Crowding," Environment and Behavior. 5, No. 4. December, 1973. 421-439.

Waugh, Benjamin. The Gaol Cradle: Who Rocks It? London: Strahan and Co., 1873. 
Webb, S.L. and David G. Morris. Prison Guards: The Culture and Perspective of an Occupational Group. USA: Coker Books, 1978 .

Wener, Richard and N. Clark. User Based Assessment of the Chicago Metropolitan Correctional Center. Unpublished report for the U.S. Bureau of Prisons, 1976.

Wener, Richard and N. Clark. "Innovative Correctional Environments," Environment and Behavior. 12, No. 4. December, 1980. 478-493.

Wener, Richard and C. Keys. Non-Density Factors and the Perception of Crowding. Submitted to the American Psychological Association, 1979.

Wheeler, Stanton. "Soclalization In Correctional Communities," American Sociological Review. 26, No. 5. October, 1961. 697-712.

Wildt, Albert R. and 0lli T. Ahtola. Analysis of Covariance. Beverly Hills: Sage Publications, Inc., 1978.

Wright, Revin N. and James Boudouris. "An Assessment of the Moos Correctional Institution Environment Scale," Journal of Research in Crime and Delinquency. 19, No. 2. July, 1982. 255-276.

Zald, Meyer N. "The Correctional Institution for Juvenile Offenders: An Analysis of Organizational Character," Social Problems. 8, No. 1. Summer, 1960. 57-67.

Zeitz, Gerald. "Structural and Individual Determinants of Organizational Morale and Satisfaction," Social Forces. 61, No. 4. June, 1983. 1089-1108.

Zohar, Dov. "Safety Climate in Industrial Organizations: Theoretical and Applied Implications," Journal of Applied Psychology. 65, No. 1. February, 1980. 96-102. 
APPENDIX

Correctional Institutions Environment Scale Form R

Rudolf H. Moos

Reprinted with permission Consulting Psychologist Press, Palo Alto, CA 


\section{PLEASE NOTE:}

Copyrighted materials in this document have not been filmed at the request of the author. They are available for consultation, however, in the author's university library.

These consist of pages:

P. $173-176$

\section{University \\ Microfilms International}

300 N. ZEEB RD.. ANN ARBOR, MI 48106 (313) 761.4700 